Universidad Nacional de La Plata

Facultad de Humanidades y Ciencias de la Educación

Secretaria de Posgrado

\title{
La Responsabilidad Civil en el Patio Escolar
}

\author{
Raúl Oscar Martínez
}

Tesis para optar por el grado de Magister en Educación Corporal

Director Adolfo Berstch, Universidad Nacional de La Plata

Codirector Gabriel Cachorro, Universidad Nacional de La Plata

La Plata, Septiembre del 2012 


\section{INDICE}

INTRODUCCION.

1. Los patios de la escuela 13, 2. Los contextos 21, 3. Patios de datos relevados en las escuelas de un distrito de la Provincia de Buenos Aires (Argentina) 31.

1. La responsabilidad civil y la escuela 38, 2 La responsabilidad (significados) 44, 3. La responsabilidad en las prácticas profesionales 47, .4. Obligaciones de los propietarios 47, 5. Articulo 1.117 del código civil. Texto ley 17.71148 , redacción original. 6. Articulo 1.117 código civil actualizado por Ley 24.830 vigente. 48, 7. Artículo 1.169 .49, 8. Artículo 1.112 48, 9. Artículo 1.113 48, 10. Artículo 1.115 48, 11. Artículo 1.116 49, 12. Artículo 1.118 49, 13. Requisitos para que resulten responsables los titulares del establecimiento educativo 50. 14. Eximentes de responsabilidad 50, 15. Propietarios 50-51, 16. Resolución 426/06 59, 17. Resolución 498/10 59, 18. Salida Educativa. Representación institucional 60, 19. Culpa de la víctima 61, 20. Culpa de un tercero 61, 21. Dolo 62, 22. Riesgos excluidos 62, 23. Profesor y su concreción en el patio 66, 24. Presupuesto de responsabilidad 67 - 68, 25. Culpa 68, 26. Responsabilidad por accidentes 69, 27. Responsabilidad derivada de los espectáculos deportivos 70, 28. Responsabilidad profesional 70.

\section{Capitulo III}

1. Encuadres legales 74, 2. Constitución Nacional 75, 3. Constitución Provincial 75 - 76, 4. Estatuto del Docente 79, 5. Circular 7/1994 84, 6. Circular 2/2010 84, 7 Circular 1/97 85, 8 Circular educación física 1/2010 87. 
1. Obligaciones Profesionales 98, 2. Las prácticas profesionales 98, 3. Trabajo de campo 106.

\section{Capítulo V}

1. Análisis 113, 2. Fragmentos de entrevistas 113, 3. Consideraciones 130.

- Conclusiones del trabajo 140.

- Responsabilidad Civil 140.

Bibliografía 


\section{La Responsabilidad Civil en el Patio Escolar}

\section{Introducción}

El presente trabajo propone una lectura sobre la responsabilidad civil en el patio escolar, donde desempeña la tarea el profesor de educación física teniendo esta una trascendencia social con respecto a las prácticas escolares en donde los aspectos legales no podrían tratarse fuera el contexto que los enmarca y los sitúa en una realidad determinada que les da vida en un análisis de situación jurídica, en la que implica considerar los aspectos históricos, sociales, regionales, culturales, políticos, económicos entre otros.

A los efectos de introducir al lector sobre el contenido del trabajo en cada uno de los capítulos y señalando la estructura de la tesis, en el capítulo inicial, refiero a los patios de las escuelas, su estado actual haciendo referencia a los contextos.

Los datos relevados en la investigación de las escuelas de un distrito permitieron descubrir los establecimientos que tienen patios, quienes están descubiertos o cubiertos, los salones de usos múltiples, los playones y quienes carecen de infraestructura adecuada para las prácticas profesionales.

Desconocer la normativa legal vigente y la sociedad jurídicamente organizada, requiere cada vez más de normas que faciliten la convivencia, evite los conflictos y prevea sanciones cuando las conductas así lo exijan. Una educación física atravesada por teorías y prácticas originadas por otros campos en los últimos años la contaminaron a la misma, donde el patio no puede estar ausente como lugar de práctica.

Siguiendo con la temática ingresamos en la responsabilidad civil y la escuela, donde el profesional trabaja en circunstancias, espacios y horas diferentes. Aparecen los significados, las obligaciones de los propietarios, las resoluciones, los accidentes, los espectáculos y las prácticas profesionales que tienen un soporte jurídico.

El código civil en nuestro país, sus artículos principales, adquisición de derechos y las obligaciones que contrae el profesor de educación física, adquieren una importancia 
determinada. Su capacidad o incapacidad nace de esa facultad que en los casos dados, les conceden o niegan las leyes.

Como manifiesta el mismo código, todos los entes susceptibles de adquirir derechos o contraer obligaciones, que no son personas de existencia visible, son personas de existencia ideal o personas jurídicas, estas pueden ser de carácter público o privado. Las de carácter público, son el estado nacional, las provincias y los municipios, las entidades autárquicas, la iglesia católica. Tienen carácter privado, las asociaciones y fundaciones que tengan por principal objeto el bien común, las asociaciones civiles y comerciales.

La investigación sobre los encuadres legales, las normativas y las circulares son analizadas conforme a las normas vigentes. La epistemología permite considerar, las relaciones existentes entre el saber y el poder, las decisiones importantes en lo relativo a las organizaciones y movimientos sociales, pudiendo distinguir dos sentidos del término sujeto relacionado con la historia, el sometido a control y la dependencia del otro como también el sujeto con la propia identidad por las prácticas y el conocimiento de sí.

Es indudable que revisar los orígenes a la luz de los acontecimientos es pensar en nuestra identidad, donde hoy vivimos expuestos a un verdadero mercado del cuerpo, la responsabilidad de cada profesor en el patio escolar los obliga a anticiparse, prevenir, planear acciones con los alumnos con seguridad y profesionalidad que al paso de los años la sociedad se ha complejizado y el abordaje de sus problemáticas han dejado a la luz que los esfuerzos aislados conllevan a resultados poco efectivos.

Previsión normal hasta lo que uno puede en la institución dentro de lo razonable, demostrando la diligencia caso contrario uno es negligente. Según se actúe en circunstancias, tiempo y lugar todos los riesgos son inagotables. El límite es lo razonable, por cada hecho que nos pase debemos conocer cuáles son los medios que tenemos en materia seguridad.

A veces nos guiamos por usos y costumbres, en las escuelas donde el profesor de educación física se mueve dentro de un marco normativo y a su vez ve muchas veces la necesidad de modificarlo o crearlo en su caso negándose, por desconocimiento o inseguridad a realizar el intento. Conocer los principios legales que le permitan al 
profesional recorrer caminos correctos para alcanzar el fin propuesto es la tarea diaria en un país aún en vías de desarrollo.

Plantear ciertas problemáticas donde aparecen las obligaciones profesionales, las prácticas y el trabajo de campo. Las obligaciones como también las responsabilidades ameritan un análisis particular de las consecuencias que el desempeño de la función profesional puede generar, siendo capaz del profesor de comprender los cambios o ser impulsor de los mismos a través de la escuela siguiendo las vías correspondientes. Todos son seres sociales, donde hay sociedad hay un derecho, aún en las agrupaciones primitivas sus integrantes debieron acatar ciertos modos de coexistencia y de respeto mutuo, porque justamente convivir implica límites y reglas de conducta recíproca, donde hay actos prohibidos y otros permitidos.

Entendiendo a la responsabilidad civil en el deber de resarcir los daños causados y los perjuicios provocados por sí o por un tercero, por lo que se debe responder. Si hablamos de contexto nos referimos al carácter situado de una interacción en un espacio - tiempo, que incluye el escenario de una interacción, unos actores presentes y una comunicación entre ellos.

Un análisis social que pone suspenso en las escuelas socialmente reproducidas y que atiende al modo en que los actores hacen registro reflexivo de su obrar, el modo que aplican las reglas y recursos en la constitución de una interacción. La escuela como organización estatal del sistema educativo separada de los movimientos sociales en la que el impacto social busca una herramienta de solución a los problemas fuera de ella de la realidad actual.

Los daños producidos en los patios de educación física a la vista de los acontecimientos en el distrito merecen que se los investigue, por lo que el inicio de este camino con la mayor objetividad posible, donde el trabajo pueda ser suficiente para pensar otros caminos posibles, teniendo una mirada para una mejor educación, pensando que estar en desacuerdo es construir una tesis mejor que aquella que criticamos.

La investigación y la disciplina se construyen y constituyen recíprocamente la una a la otra. Prácticamente todas las distintas maneras de pensar la responsabilidad civil han sido producto de miradas que se realizaron desde otras ciencias. Seguramente a nivel 
profesional, el problema siempre fue analizado desde otros campos que ha incorporado esas miradas a la propia, habiendo asumido como propio ese papel.

A nivel profesional, el problema que se plantea habitualmente y que se revela en algunos textos, remite a la idea de tener en cuenta la normativa legal vigente, problema en el que el rol profesional queda atrapado en distintos aspectos como la enseñanza, instrucción, aprendizaje y otros.

Entiendo que desde hace largo tiempo la Educación Física no ha cesado de reclamar el lugar propio, de identidad, con problemas legales y no dependiente como subordinada a las ciencias biológicas y psicológicas. La responsabilidad civil en las prácticas del profesor implica considerar al sujeto en su historia, las instituciones y las sociedades en la que se desarrollan las prácticas del profesional.

Intento indagar en los procesos, en los hechos o daños, en las estructuras y prácticas en las que se manifiesta la responsabilidad. Romper con la idea del modelo, o del deber ser, reconstruir los modos y los distintos procesos en el que se ha constituido. La Educación Física la observamos como campo de las prácticas sociales, que cumple una función social, sistemática, que se expresa en las instancias institucionales, familia, escuela, formación y comunidad siendo interesante ver como se generan y se sancionan determinadas prácticas, que generan una cultura específica, formas de hacer y ser.

Tomar distancia de la propia práctica, que nos permita reflexionar sobre las condiciones en que se encuentra el estado actual de los patios, los horarios del dictado de las clases como las circunstancias en que se desarrollan las configuraciones de movimiento.

Con la investigación de la responsabilidad civil en las prácticas del profesor implica estar en el problema, convivir con el mismo, responsabilizarse por este, imponiendo tomar distancia, por ende crítica, que permita ver las situaciones en los contextos.

El análisis de los patios de la escuela, el estado actual de los mismos como también los distintos lugares que se utilizan para el dictado de las clases, indica el estado actual de los lugares. 
La responsabilidad civil y la escuela, los significados, el daño, derecho, los riesgos en la Institución con los alumnos y el código civil, su artículo reformado el 1.117, las demandas, el conocimiento, los interrogantes, las prácticas en el patio escolar y las autoridades escolares indican un camino.

El texto actualizado del artículo del código civil 1.117, los artículos 1.109, 1.112, 1.113, $1.115,1.116,1.118$. La ley establece un límite entre lo que se permite y lo que está prohibido en las prácticas del patio.

Aparecen las resoluciones, las salidas educativas, de representación institucional, análisis de la culpa, dolo y riesgo. También la responsabilidad por accidentes, la derivada de espectáculos deportivos y la profesional.

El encuadre legal, las normativas y circulares correspondientes en la prevención de accidentes y pautas para el dictado de clases en el medio acuático. También circulares de educación física. En cuanto a las normativas expresan una cierta gradualidad entre un más y un menos, conceptos graduales de la misma.

Las obligaciones profesionales analizadas desde las prácticas profesionales, la función del profesional, la órbita jurídica, clarificación de las normas y daños. Trabajo de campo. En el mismo veremos si la norma es efectiva al ser gradual que normaliza en donde el espacio de esta se verá si está legislado o no. Conceptos de actualidad en las prácticas cotidianas donde se desempeña el profesor de educación física.

Patios atravesados por discursos institucionales en continuo cambio con las variables del tiempo, espacio debe brindar certezas y los diseños de proyectos sería importante que interpreten lo que dice la institución. En el inicio de los capítulos veremos lecturas institucionales, elementos importantes de la organización como de la administración escolar.

Los edificios escolares, con patios escolares poco preparados para las clases de educación física. Lo instituyente es el cambio, el movimiento mientras que lo instituido es la seguridad y la identidad de cada lugar. El tiempo escolar y que hace el profesor en el patio con ese tiempo, las políticas y el espacio determinada de las escuelas pensados para recreos. 
Un sujeto sujetado a la institución, donde veremos contradicciones, con seguridades que no se deberán perder. El lector podrá darse cuenta en el trabajo a medida que lee cada capítulo que la administración será el punto central en la función de la escuela, donde existen improvisaciones como los permisos que se toman.

La arquitectura escolar genera asimetría de poder que normaliza cuerpos, e identifica a la institución educativa, se analizará el tiempo y el espacio como el poder. Los espacios para los recreos o clases de educación física, la disputa de los mismos, las maneras de usar el tiempo, temporalidades individuales, proyectos, toma de decisiones.

A medida que transcurre los escritos de la tesis podrá el lector apreciar las informaciones del estado actual, la reflexión, comparación y conclusión de la normativa y lo estratégico que permiten establecer los contextos relativamente estables y los cambiantes y complejos.

La responsabilidad civil es espacial y temporal donde el profesional de educación física desempeña su tarea de una escuela a otra perdiendo su independencia y autonomía en debiendo trasladarse rápidamente como profesores taxi. Prevenir o anticipar es adelantarnos a posibles hechos que pueden producir daños en nuestros alumnos considerando que es un tema de actualidad que los profesionales no pueden desconocer.

Fundamental analizar los discursos de profesionales explorando los impactos de esta época revisando el estado actual de los patios escolares. Aportes de abogados, directivos y profesionales con las indagaciones sobre datos aportados de infraestructura como de necesidades reales como las denuncias de falencias son considerados en el trabajo como también los conceptos de norma y ley son tenidos en cuenta sobre el estado actual de las normativas y documentación sobre los códigos.

La responsabilidad civil en los patios dependientes de la provincia impacta en las instituciones escolares. La elección de estos temas en un trabajo de investigación, quisiera poder describir brevemente dos demandas que podrán de alguna manera responder el inicio de este camino en la tesis y lo cotidiano del trabajo del profesor de educación física que en el patio día a día se encuentra con este problema que es la "Responsabilidad Civil en las prácticas profesionales de la escuela". 
La primera demanda:

La fecha de ingreso de esta demanda es en Abril del año 1993 a las 8,10 has, por daños y perjuicios. El día 6 de diciembre del año 1992 falleció ahogado (asfixia por inmersión) en un balneario del partido de un distrito de la provincia de Buenos Aires.

Se demanda los daños y perjuicios sufridos y originados por dicho suceso. El 6 de diciembre del año 1992 se habría publicado con gran difusión que en esa fecha se llevaría a cabo la Inauguración oficial de la temporada estival 1992 / 1993 correspondiente al citado balneario, lo cual estaba con-organizado por el municipio, asociaciones y profesores de educación física.

La programación o programa de actos daba informe que la ceremonia comenzaría a las 10 horas con la disputa de un partido de fútbol infantil, a las 10,30 horas se produciría la actuación de la banda municipal y a las 11,30 horas se llevaría a cabo la inauguración con la presencia de autoridades del municipio, la bendición de las aguas del balneario y toda una fiesta a la que no podía estar indiferente la población lugareña. En dicha organización se prometió el envío de guardavidas tal como lo habían hecho en temporadas anteriores.

En el evento estuvieron presentes unas 500 personas, muchas de las cuales se internaron en las aguas del mencionado balneario. El guardavida no fue enviado. El joven y otras tantas personas menores y mayores concurrieron al evento organizado con tanta difusión, y participo en el mismo tratando de disfrutar de lo que un balneario nos puede brindar.

El joven se encontraba bañando en el lugar con otros jóvenes de su edad con quienes jugaba y hacia bromas, nadando en el balneario. Horas más tarde el cuerpo sería rescatado. La demanda menciona que el acontecimiento que contaba con la presencia aproximada de 500 personas, no menos de 3 guardavidas eran necesarios.

Fue un acto de grave imprudencia no enviarlos como lo habían prometido, según lo expresa la solicitada y fue una omisión indisculpable el haber permitido el ingreso de bañistas al balneario, que carecía del conocimiento de la falta de apoyo en un balneario habilitado por el municipio como tal. 
Se violaron por todos los organizadores y auspiciantes normas y conceptos de mínima seguridad. Toda señalización estaba ausente, motivo por el cual los bañistas desconocían cuales eran los lados seguros, si es que en realidad ellos existen.

En la demanda decía que la persona no se ahoga solamente por no saber nadar, o también por las limitaciones. Cualquier indisposición puede provocar un cuadro que el mejor nadador le impida sin ayuda de tercero alcanzar la costa. Existió culpa de los con-demandados, los cuales violaron mínimas normas de seguridad. Las entidades o asociaciones participantes de un espectáculo público deportivo son solidariamente responsables civiles de los daños sufridos por los espectadores de los mismos en los estadios durante su desarrollo, si no ha mediado culpa por parte del damnificado.

El deber de seguridad que asumen los organizadores del evento estaba omitido, que después del accidente del joven con continuidad existió la cobertura de un guardavidas en el balneario. Es impensable que se habilite un balneario sin exigir al concesionario o explorador el cumplimiento de dicho recaudo. El balneario no podía funcionar como tal el día del evento, por no reunir condiciones de mínima seguridad, porque no existían carteles indicadores de los ámbitos permitidos y los prohibidos, porque no existían un mínimo no respaldo de vigilancia y seguridad.

Nadie sabía los riesgos que corría y la falta de apoyo como de auxilio. La publicación de la inauguración del balneario, con un trampolín, y sin carteles indicadores de los lados seguros y los que no lo eran, sin respaldo de guardavidas, fue una actitud imprudente, negligente e indisculpable que debe ser sancionada y condenada. Secretaría de turismo informo que por razones presupuestarias, y como lo viene haciendo en años anteriores, la municipalidad cubre el servicio de guardavidas a partir del mes de enero y hasta el 28 de Febrero de cada año. Asimismo cabe destacar que la designación se realiza a partir de enero por requerirse previamente la prueba que a los guardavidas realiza la provincia, requisito indispensable para habilitar la designación de ese personal.

Con esta demanda se reclama el resarcimiento económico integral de los perjuicios originados y sufridos por nuestros comitentes como consecuencia del hecho.

En el evento participaron de la organización profesores de educación física, del cual siempre se les pide colaboración, juegos de recreación, deportivos, competiciones y respuestas a distintas organizaciones. 
La segunda demanda:

Se entabla demanda de daños y perjuicios, contra el establecimiento educativo, contra el profesor de educación física, contra la compañía de seguros y solidariamente contra la Dirección General de Cultura y Educación de la Provincia de Buenos Aires correspondiente al hecho dañoso el día 10 de Septiembre del 2002 en el que un alumno sufre un accidente en la clase de educación física.

En la misma dice la demanda no se llamó a la ambulancia, como sería lo correcto por parte del educador, que no lo hace, advirtiendo en esa actitud, una negligencia imputable al mismo, por ende a la Institución y a las entidades a las que representa directa o indirectamente. Luego del accidente se le diagnóstico al alumno rotura de ligamentos cruzados en la rodilla derecha.

Se enviaron carta documento a la empresa de seguros, a la Dirección General de Cultura y Educación y al Director del Establecimiento. En la demanda se habla de responsabilidad objetiva y subjetiva del establecimiento y de la empresa de seguros solidariamente de la Dirección General de Cultura y Educación de la Provincia de Buenos Aires, se reclaman montos y se fundamentan los reclamos.

Estas dos demandas cómo otras impactan cotidianamente en las prácticas de profesionales de la educación física.

El cuidado del cuerpo considerado desde la propia práctica adquiere una trascendencia más allá de lo meramente físico, cuando se lo interpreta no solo como medio para el mantenimiento de la salud, sino requisito que lleva a preservar la integridad de las personas.

Una mirada desde lo profesional respecto a este tema tan importante que se encuentra en nuestras prácticas cotidianas desde que iniciamos hasta que finalizamos.

Los conceptos de norma y ley son importantes en el cuidado del cuerpo, para cada acción hay un soporte jurídico y además desde que los alumnos ingresan hasta que egresan de la clase de educación física están a nuestro cuidado, por lo tanto si hablamos del cuidado del cuerpo es muy importante tener un saber sobre este tema preocupante y de candente actualidad. 
"La responsabilidad civil con relación al cuidado del cuerpo como eje transversal que cruza las acciones de las prácticas del profesor en el contexto actual del patio de la escuela"

"La responsabilidad civil se ha convertido en el contexto actual a la luz de las situaciones que cotidianamente impactan en las acciones de los profesores de educación física en una cuestión frente a la cual ya no es suficiente la sola referencia a la normativa vigente"

Los profesores de educación física que ejercen funciones en los establecimientos de enseñanza estatal, dependientes de la Dirección General de Escuelas y Cultura de la provincia de Buenos Aires o en sus organismos con deberes y derechos. Imparten, guían la educación, dirigen, supervisan u orientan la enseñanza en cualquiera de los niveles, modalidades y especialidades. 


\section{Capitulo I.}

\section{Los Patios de la Escuela.}

En la Introducción partimos de un interés sobre el estudio de la responsabilidad civil en el patio, lugar emblemático, interpretando múltiples cualidades del mismo y sus modos de uso como espacio actual de recreo. ${ }^{1}$ Recorrido del mismo intentando descifrar el estado actual de los mismos, no proponiendo un modelo único, sino pretendiendo saber del estado actual, para construir una visión general y aproximada de un territorio plural y que estos resulten útiles para la construcción colectiva.

Intentar ver y revisar los criterios con que se diseñan los mismos, los aportes para la construcción de edificios escolares, los accidentes que puedan ocasionar, la seguridad, si es cubierto o no y las dimensiones del mismo,

El estado actual de los patios ${ }^{2}$ no es el mejor, gracias a los aportes de Provincia, Consejos Escolares, Directivos, profesores, cooperadores se puede presentar un contexto adecuado para las prácticas corporales y los patios pueden ser utilizados en menor medida. El estudio de los contextos es inherente a la investigación de una reproducción social. Contexto supone, los límites del espacio y del tiempo, la presencia de actores que hacen posible la visibilidad de una diversidad en todas las expresiones.

Es sabido que los padres delegan en cada uno de los maestros la responsabilidad en la escuela y en el patio a los profesores de educación física, velando estos por la seguridad de sus hijos en sus prácticas corporales. Cuando recordamos hechos en las prácticas de numerosos profesionales que tienen que ver con la responsabilidad civil vienen a nuestra memoria los cuestionamientos que se formulan a quienes supuestamente o no le correspondía haber tomado las medidas necesarias para que no les sucediera tal o cual hecho. También en la misma proporción, escuchamos los descargos de quienes se vieron involucrados, pero lamentablemente, esas sólo son palabras que buscan responsables o procuran quitar esa responsabilidad.

Durante épocas los profesores se reunían en cada escuela y en las Instituciones donde se preguntaban por el patio de la escuela y su seguridad. El juego en la clase,

\footnotetext{
${ }^{1}$ El Patio escolar: el juego en libertad controlada. Victor Pavia. 2005.

${ }^{2}$ Referencia a un distrito de la provincia de Bs.As.
} 
en los recreos, la diversión, las emociones y cada una de las satisfacciones merecen un espacio seguro.

En las Reformas Educativas ${ }^{3}$ no se hablaba de los patios, de su seguridad y a los profesores de educación física se los identificaba con el patio de la escuela donde pasan gran parte de su profesión.

Me pregunté en épocas de Reformas ¿Por qué estas se realizan tan rápidamente?. Son tan rápidas que no nos dejaban pensar y si teníamos en claro como estaban las condiciones edilicias en aquellos años. ¿Estábamos los profesores preparados para la misma? ${ }^{4}$

Desde los lugares de trabajo los profesores hoy siguen luchando por un lugar digno para su clase de educación física. Algunos tienen un salón de usos múltiples, otros un playón, un patio, unos pocos el gimnasio, otros ni siquiera lo tienen. Permitirme investigar el distrito, donde estamos parados respecto a los patios de educación física en cada una de las escuelas, sean rurales o urbanas y la problemática de la responsabilidad civil es una tarea a iniciar.

En la actualidad son muy pocos los cargos históricos y con profesores que están a punto de jubilarse. Esos cargos permitían la identificación con su escuela, en la actualidad inician el trabajo a través de módulos que comparten en distintas escuelas.

Es posible que algún día la concepción actual del patio del juego en la escuela y la seguridad sea prioridad. El capitalismo de consumo está a la orden del día, regulando las actividades de ocio y consumo creando necesidades que se acoplen a productos que están interesados en vender, transformarlo, etc. La promulgación de la Ley Nacional de Educación 26.206 y de la Ley 13.688 de Educación provincial marca un rumbo distinto a las anteriores, están los derechos, los deberes y las reglas en la que interpretarlas como ponerlas en prácticas es indispensable.

Quizás uno de los principales riesgos en los trabajadores del patio escolar sea del desconocer los derechos sobre la importancia de las normas de prevención. No conocer los derechos que le confieren las normas vigentes y de los riesgos a los que

\footnotetext{
${ }^{3}$ Referencias a las Reformas Educativas en el país. Argentina. Ley Federal de educación. Enero 1995.
} 
se exponen, por falta de capacitación o mal estado del patio nos invita a reflexionar sobre este tema tan importante como la responsabilidad civil.

Los recursos y reglas poseen una implicación recursiva en la reproducción social, mientras que todos los aspectos institucionalizados de los sistemas sociales poseen propiedades estructurales en el sentido de que por un tiempo y por un espacio sobradas relaciones que se estabilizan.

Las prácticas institucionalizadas conectan a la integración social con la integración sistémica. En las actividades los actores sociales como sucesos de la naturaleza se auto-reproducen, son recursivas, equivale a decir que no les dan nacimiento sino que las recrean de continuo y por ellas los agentes reproducen las condiciones que hacen posibles esas actividades. Una acción humana ocurre con una duración, un fluir de conducta continua y una acción intencional no compone de una serie o agregado de intenciones, razones y motivos distintos.

Reconstruir los espacios de práctica, los patios de los profesores, los escenarios es cuidar a nuestros alumnos de las escuelas, a que ellos tengan en el aula del patio el tiempo y espacio digno para cumplir con tiempos de práctica motriz que son demandados socialmente y a los profesionales de la educación física cuyo cuidado debería garantizarlo el estado.

Los compromisos normativos abarcan un sector de la racionalización de la acción. Si no entendemos esto, desconoceremos que las normas constituyen límites de la vida social y es posible una diversidad de actitudes manipuladoras.

Compartir las inquietudes y contribuir antes los políticos de turno, directivos y padres para que juntos puedan encontrar la forma de construir y dar seguridad a esos patios es importante. Las escuelas observadas en el distrito permiten iniciar un camino a la reflexión por el bien de los alumnos y la sociedad en su conjunto.

Los actores no solo registran por rutinas aspectos sociales y físicos de los contextos, casi siempre tienen una comprensión teórica continua sobre los fundamentos de su actividad.

El Juego en el patio de esas escuelas como en otras son escenarios de problemáticas diversas y escasa investigación, los trabajos sobre el patio escolar de recreo 
fundamentalmente han sido realizados desde disciplinas consolidadas como la Sociología, Antropología, Psicología, Arquitectura, entre otras.

Pareciera que la toda la preocupación de los espacios escolares se limitara casi siempre a círculos de profesionales directamente involucrados en las dependencias que tienen a su cargo toda la construcción de edificios. Observar a los niños en el patio durante el recreo o en la clase de educación física invita a distintas problemáticas pero quién se anima a discutir que el patio es uno de los lugares más públicos de la escuela.

Seguramente a los profesores los identifican con el patio de esas escuelas, es donde pasan gran parte de la vida profesional y por lo tanto lo conocen. Recordar los hechos y lugar hace que nos remonte al pasado histórico de la escuela. La diversidad de la escuela tiene que ver con la historia y la escuela de la diversidad tiene que ver con la negociación como con los consensos en la educación actual, pero el futuro es incierto.

Al hablar de la seguridad del patio es hablar también de los riesgos que nos invita a observar las acciones de los alumnos. No pretendo analizar los comportamientos indebidos o darles consignas como dicen las maestras, pero si analizo las condiciones edilicias donde se desarrolla el juego y que hacen para mejorarlos. Las actividades que repiten los profesionales de la educación física, localizadas en un contexto de tiempo y espacio, tienen consecuencias regularizadas.

Ser capaz de obrar de otro modo significa ser capaz de intervenir y una acción nace de la aptitud del individuo para producir diferencias sustanciales en los lugares de práctica. En el patio se comparten miradas, no es lo mismo el profesor que el asistente social, maestra de turno, director, portero, padre, etc. Ese patio lugar ocupado por cuerpos, es un espacio interior de un espacio más amplio que es la escuela.

Las prácticas que poseen mayor extensión espacio-temporal en el interior de totalidades se pueden denominar instituciones.

Regla es más o menos equivalente a hábito o rutina, concierne a numerosos aspectos de una práctica rutinaria, pero una práctica rutinaria no es como tal una regla. Son procedimientos de acción, aspectos de una praxis. Considerar las reglas sociales, como técnicas o procedimientos generalizables que se aplican a la escenificación/reproducción de prácticas sociales es importante. 
Entender cada uno de los procedimientos o dominar las técnicas de "hacer" en la actividad social, es por definición metodológica en las prácticas sociales, o sea ese entender no especifica todas las situaciones con la que los actores pueden llegar a encontrarse, más bien proporciona la aptitud generalizada de responder a un espectro indeterminado de circunstancias sociales y de influencia sobre este. Los tipos de reglas más significativos se alojan en la reproducción de prácticas institucionalizadas o sea prácticas sedimentadas a la mayor profundidad en un espacio-tiempo.

La mayor parte de las reglas que intervienen en la producción y reproducción de prácticas sociales son aprehendidas sólo tácitamente por los actores. Los aspectos más importantes de estructura son reglas y recursos envueltos en instituciones. La conducta de actores individuales reproduce las propiedades estructurales de colectividades mayores. Las reglas cuando se dividen en modos significan o constituyen sentido y sanciones normativas. Agregar que la comunicación del sentido en una interacción analítica es separable de operaciones de sanciones normativas.

Los individuos se constituyen con independencia de los escenarios sociales que enfrentan en su vida cotidiana. La educación tiene la función de asignar individuos, confunde las diferencias entre aspectos intencionales y no buscador de una reproducción social. Mientras que la jerarquía formal de la escuela, asimila modos de conducta y expectativas normativas, que tienen amplia difusión por diferentes sectores de la sociedad, aunque influyan en ellos fuertemente las divisiones de clases.

La escuela como sede está separada físicamente del lugar de trabajo y también en el tiempo se separa de la experiencia laboral en los recorridos de la vida de los niños.

Aunque escuela y lugar de trabajo comparten pautas generales de poder disciplinario, estos no son meros aspectos de una forma institucional única.

La Sociedad tiene dos acepciones principales, una es la connotación generalizada de "asociación social" o interacción, la otra es la acepción según la cual "una sociedad" es una unidad cuyos límites la deslindan de otras sociedades que la circulan. Los estados nacionales tienen límites territoriales deslindados con claridad y precisión, pero no ocurre lo mismo con otras sociedades. 
Las sociedades humanas, o los sistemas sociales no existirían sin un obrar humano. Pero no ocurre que los actores creen sistemas sociales, ellos los reproducen o los transforman y recrean lo ya creado en la continuidad de una praxis. Se distinguen dos tipos principales de colectividades según la forma de las relaciones que intervienen en la reproducción:

Las "asociaciones", "organizaciones" y también los movimientos sociales. ${ }^{5}$ En las asociaciones, como en todos los sistemas sociales, una reproducción social ocurre en la conducta regularizada de agentes entendidos y a través de ella. Los escenarios de interacción en los que ocurren los encuentros de rutina son registrados reflexivamente por sus actores constituyentes en la reproducción de relaciones de rol que presentan eslabonamiento mutuo.

Las organizaciones y los movimientos sociales son colectividades en que la regulación reflexiva de las condiciones de reproducción sistémica aparece magnificada en la continuidad de prácticas cotidianas. A diferencia de las organizaciones, los movimientos sociales no operan en general dentro de sedes fijas y la postura en el interior de ellos no presenta la claridad de definición asociada a "roles".

Las sociedades son más que la suma de los individuos que las constituyen y los seres humanos viven en las sociedades y crean culturas. La comunicación es la base de la cultura y el lenguaje es la base de la comunicación. El espacio es entendido como continente de todos los objetos que existen, habitado por sujetos concretos que son los alumnos y los docentes, en una situación concreta de descanso y esparcimiento.

El ambiente físico condiciona las modalidades de conducta que se forman en el interior de las sociedades, o les ponen límites, pero el sistema cultural es el que las regula de la manera más directa.

La regla, respecto al patio escolar significa acuerdos en el mismo. Se conciben con frecuencia en conexión con juegos, con prescripciones formalizadas. Implicadas en la reproducción de sistemas sociales no se parecen en general a esas. Aunque las codificadas como leyes están en general sujetas a una diversidad mucho mayor de cuestionamientos que las reglas de juegos. No se podría conceptualizar reglas aparte de recursos, que denotan los modos por los cuales relaciones transformativas se

\footnotetext{
${ }^{5}$ Anthony Giddens, la constitución de la sociedad. Bases para la teoría de la estructuración. 2006. P.228 229
} 
integran, en acto, a la producción y reproducción de prácticas. Denotan por un lado la constitución de sentido y por otro los modos de conducta social.

La división de reglas en modos de significar o constitución de sentido y sanciones normativas, junto el concepto de recursos, fundamental para la conceptualización del poder, trae consigo varias implicaciones que son importantes.

Si intento infringir las reglas del derecho, ellas reaccionan contra mí de manera de impedir un acto si todavía es tiempo, o de anularlo y restablecerlo bajo su forma normal si es un acto consumado y reparable, o de hacérmelo expiar si no puede ser reparado de otro modo. Todos los seres humanos tienen que superar las restricciones del cuerpo, sus medios de movilidad y de comunicación. Son agentes entendidos, esto significa que todos los actores sociales saben mucho sobre las condiciones y consecuencias de lo que hacen en su vida cotidiana.

Los actores son capaces de explicar discursivamente lo que hacen y las razones de su hacer, aunque el entendimiento de los actores humanos está siempre acotado en parte por el inconsciente y en parte por condiciones inadvertidas. El tiempo que destinan a las prácticas los profesores de educación física es considerablemente poco, es reversible en las instituciones en tanto la condición como el resultado de las prácticas organizadas en la continuidad de una vida diaria, la principal forma sustantiva sea la dualidad de la estructura.

No sería correcto decir que las rutinas de una vida diaria son el fundamento sobre el que se edifican formas institucionales de organización societaria en un espacio-tiempo, más bien unas entran en la constitución de otras, así como unas y otras lo hacen en la constitución del propio ser que actúa. Tiempo reversible es duración de la experiencia cotidiana y larga duración de las instituciones. Tiempo irreversible es el lapso de la vida del individuo.

Los administradores de una escuela no suelen encontrarse con los mismos problemas de "envase" que sus homólogos de hospitales. Pero como todas las organizaciones disciplinarias, las escuelas operan con una precisa economía de tiempo. Sería correcto remitir hasta cierto punto los orígenes de la disciplina escolar a la regulación del tiempo y del espacio que se vuelve posible en una transición generalizada al "tiempo cronológico". 
No se trata de que el uso difundido de relojes permita divisiones exactas del día; se trata de que el tiempo entre en la aplicación calculadora de una autoridad administrativa. El tiempo-mercancía articulado en los mecanismos de la producción industria, quiebra la diferenciación de ciudad y campo que era característica de las sociedades divididas en clases.

Si hablamos de estructura, las reglas, los recursos, o conjuntos de relaciones de transformación se organizan como propiedades de sistemas sociales. Se entiende siempre como una propiedad de sistemas sociales, de la que son "portadoras" de prácticas reproducidas inmersas en un tiempo y un espacio. Los sistemas sociales se organizan en sentido jerárquico y lateral inferior de totalidades societarias cuyas instituciones forman conjuntos articulados.

Los sistemas, son relaciones reproducidas entre actores o colectividades, organizadas como prácticas sociales regulares y la estructuración son las condiciones que gobiernan la continuidad o trasmutación de estructuras, en consecuencia, la reproducción de sistemas sociales.

El desarrollo de la teoría de la estructuración ha introducido dos nociones que tienen alguna concernencia: los conceptos de sede y de disponibilidad de presencia como están implícitos en las relaciones entre integración social e integración sistémica.

La constitución de sedes sin duda se basa en los fenómenos a los que Hagerstrand concede lugar de privilegio: el cuerpo, sus elementos de movilidad y de comunicación, en relación con las propiedades físicas del mundo circundante. Sedes proveen buena parte de la fijeza de instituciones situadas, aunque no existe un sentido claro en que determinen esa fijeza. Por lo común es posible definir sedes en los términos de sus propiedades físicas, sea como rasgos del mundo material o más generalmente como una combinación de esos rasgos y de artefactos humanos.

Sedes pueden ir desde una habitación en una casa, una esquina callejera, la planta de una fábrica, pueblos y ciudades hasta las áreas territorialmente deslindadas que ocupan los estados. Una de las razones en las que nos lleva a usar el término sede más que lugar es que propiedades de escenarios reciben un uso sistemático por parte de los agentes en la constitución de encuentros por un espacio y un tiempo.

\section{Los Contextos.}


a) los límites espacio-temporales.

b) La co presencia de actores, que hace posible la visibilidad de una diversidad de expresiones, gestos y otros medios de comunicación.

c) Una noticia y un empleo reflexivo de estos fenómenos para influir o gobernar.

El lugar además de sustantivo oficia como adjetivo, el mismo no se emplea en teoría social simplemente para designar "punto en el espacio", como tampoco podemos hablar de puntos en el tiempo como una sucesión de horas. Esto significa que el concepto de presencia, o más bien, de la mutualidad de presencia y ausencia se tiene que explicar en los términos tanto de su especialidad como de su temporalidad.

El poder en sistemas sociales disfruta de cierta continuidad en tiempo y espacio presuponiendo relaciones reguladas de autonomía y dependencia entre actores o colectividades en contextos de interacción social. Todas las formas de dependencia ofrecen ciertos recursos en virtud de los cuales los subordinados pueden influir sobre las actividades de sus superiores. Se denomina dialéctica del control en los sistemas sociales.

El poder de lo político y de la política en los patios marca la norma pudiendo decir que el poder es lógicamente anterior a la subjetividad, a la constitución del registro reflexivo de la conducta (manifestación o expresión del ser). El aula es contenedora de poder al igual que la escuela.

Una disciplina por vigilancia es un medio poderoso de generar poder, pero depende, sin embargo, del acatamiento más o menos continuo de quienes son sus súbditos. El control del cuerpo forma parte de la novedosa "anatomía política" y en tanto tal dice Foucault, aumenta el producto del cuerpo al mismo tiempo que reduce su independencia de orientación. La disciplina no tiene otro camino que el manipular un tiempo y un espacio, requiere un cerco, una esfera de operación clausurada y cerrada sobre sí misma.

Cada individuo tiene su "lugar correcto" para cada momento particular de la jornada. Foucault habla de un "espacio analítico", donde es posible vigilar y evaluar a los 
individuos, medir sus cualidades. El carácter de un espacio disciplinario, no deriva en primer lugar de la asociación de una organización con un sector específico de territorio, sino de la administración de un espacio.

Líneas, columnas, intervalos medidos entre paredes, son rasgos definidos y lo que importa no es una parte determinada del edificio, sino su forma relacional en general. Las clases se deslindan a intervalos regulares en hileras delimitadas, se trata de divisiones curriculares no menos que espaciales. Los individuos se mueven siguiendo esas particiones no sólo en el curso de la jornada sino también durante la carrera educacional.

Las organizaciones en "lugares", "celdas", las disciplinas crean espacios complejos que son al menos arquitectónicos, funcionales y jerárquicos. Son los espacios los que otorgan posiciones fijas y permiten circulación. Recortan segmentos individuales y establecen lazos de operación, marcan lugares e indican valores, garantizan obediencia de individuos, pero también una mejor economía de tiempo y de gestos.

Un poder disciplinario no consiste sólo en la imposición de un control sobre gestos específicos, sino que alcanza su culminación donde los gestos se relacionan con una postura del cuerpo como un todo.

No hay duda de que un poder disciplinario sólo se puede generar de una manera sistemática por el "envase" de seres humanos en escenarios específicos físicamente deslindados.

Una rutina es inherente tanto a la continuidad de la personalidad del agente, al paso que él anda por las sendas de actividades cotidianas, cuando a las instituciones de la sociedad, que son tales sólo en virtud de su reproducción continuada. Las rutinas de vida cotidiana son fundamentales aun para las formas más elaboradas de organización societaria. El carácter habitual y que se da por supuesto, del grueso de las actividades de una vida social cotidiana, la prevalencia de estilos, formas familiares de conducta que sustentan un sentimiento de seguridad ontológica y que reciben sustento de este.

El cuerpo es el lugar del propio ser activo, pero el propio ser no es desde luego una mera extensión de las características físicas del organismo que su portador. Teorizar sobre el cuerpo lleva a formular una concepción de la motivación y a relacionar la 
misma con las cualidades consientes e inconsciente. El propio ser no puede ser entendido fuera de la historia, donde la misma significa la temporalidad de prácticas humanas. Un cuerpo disciplinado es un cuerpo entrenado; diríamos que en esto se prolonga la acepción tradicional de "disciplina". La postura del cuerpo es el principal factor que media entre dos secuencias temporalmente articuladas.

La preocupación fundamentalmente son los hechos y las responsabilidades en los daños que puedan ocasionarse en el espacio escolar donde se desarrollan numerosos e infinitos juegos en el patio. Al iniciar el tema reflexiono no sólo sobre la seguridad escolar y la de nuestro patio sino sobre el contexto actual donde se desarrollan los juegos.

Fijar el marco legal de referencia que es básico para futuras medidas. Ese marco no ha sido socializado adecuadamente, no forma parte en su mayoría de la formación de grado y escasamente en la capacitación. Sería atinado suponer que las intersecciones entre regionalización y la expresión del cuidado del cuerpo se enlazan estrechamente con el sostenimiento del sistema de seguridad básica.

El tema "responsabilidad civil de las prácticas profesionales en el patio", nos permitiría en el contexto de la escuela poder desarrollar conceptos que son visibles para tratar lo invisible. No hay duda de que trazar el mapa de las pautas espacio-temporales que siguen alumnos, maestros y otro personal de una escuela es un artificio topológico útil para iniciar el estudio de una escuela. Pero en lugar de emplear las formas de representación exacta es importante proponer el acento en el tiempo reversible de una conducta de rutina cotidiana.

En tanto una escuela es un tipo de organización social que se concentra en un local que posee precisas características físicas, sus características se pueden entender por referencia a tres aspectos: la distribución de encuentros que se producen en su interior por un tiempo y un espacio, la regionalización interna que muestra, y la contextualizad de las regiones así individualizadas.

El responsable constitucional de la organización del sistema educativo provincial como propietario de las escuelas públicas debería replantearse estas problemáticas. Con esto quiero significar que cualquier plan que se ponga en marcha para prevenir no elimina ni anula la responsabilidad directa del propietario. 
Una escuela es un contenedor que genera poder disciplinario. La naturaleza cercada de la vida escolar vuelve posible una coordinación estricta de los encuentros seriales en que intervienen los internos. Los segmentos de su tiempo que los niños pasan en la escuela están espacial y temporalmente segregados de encuentros potencialmente intrusivos externos. Pero esto se aplica también, al menos por lo común, a las divisiones entre diferentes clases.

Las escuelas tienen particiones internas, estas pueden ser áreas de una escuela, pero también ciertos momentos en que ocurren formas de interacción heterogénea o difusa. La distribución de encuentros en el interior de una escuela presenta un vivo contraste con sectores de la vida social en que la regulación de la normativa de la actividad es más laxa.

La fijación de espacios disciplinarios forma parte del carácter arquitectónico de las escuelas, tanto en la separación de aulas como en el espaciamiento normado de pupitres que suelen encontrarse dentro de ellas. No hay duda de que divisiones espaciales de este tipo facilitan la especificación de rutinas y la asignación de tareas.

El concepto sociedad, que es la unidad principal de análisis en las ciencias sociales, es preciso examinar con cuidado este término. Los profesionales se preguntan cotidianamente.

¿Qué dice la ley al respecto?

"Pienso que en el estatuto que está todo muy claro"

"Aquí en la escuela tenemos reglas de convivencia"

"A veces las normas se acatan pero no se cumplen"

"Somos muy de estar con el reglamento"

"tomar un permiso social"

La norma es evocada cotidianamente con distintos nombres, a propósito de diferentes temas, llamadas para auxiliar determinadas circunstancias, convocadas para restringir en otras, nombradas como resguardo, silenciada, ignorada, etc. 
Es curioso en la manera en que las normas están presentes en las instituciones educativas por lo general, las más invocadas no remiten a la dimensión pedagógico didáctica. Podemos decir que la manera en que los actores conocen, interpretan, producen y se posicionan frente a la norma nos da una información significativa para construir un saber sobre la institución. Hay que distinguir claramente los conceptos de norma y ley.

La disciplina está del lado de la norma y no de la ley, sería una forma de normalización de la disciplina. La pregunta sería:

¿Cómo se diferencian?

"La ley establece un límite entre lo permitido y lo prohibido"

La norma expresa una cierta gradualidad entre un más y un menos. Hay una media a la que se aproxima o de la que uno se aleja. Para la ley no hay más o menos permitido, es permitido o no, pero para la norma hay más o menos normal. La idea de responsabilidad en su acepción cotidiana expresa con justeza la intersección de esquemas interpretativos y de normas. Ser responsable de las propias acciones es tanto explicar las razones de ellas como ofrecer los argumentos normativos que las puedan justificar.

Los componentes normativos se centran siempre en relaciones entre los derechos y obligaciones que se esperan de quienes participan de contextos. Códigos formales de conductas, como las leyes expresan una suerte de pretendida simetría entre los derechos y las obligaciones, donde unos son la justificación de los otros. Los elementos normativos de sistemas sociales son demandas contingentes que deben ser sustentadas y puestas en vigencia a través de la movilización efectiva de sanciones en los contextos de encuentros.

La norma es un concepto gradual, en cambio en la ley están los códigos, por ejemplo el "Código Civil". La norma se refiere al campo de los saberes que non de las ciencias humanas, ciencias de lo normal. La ley, estableciendo lo permitido y lo prohibido crea en los hombres exclusiones. Sin norma no hay disciplina, porque el espacio de la norma es aquello que no está legislado. El juego en el patio y su seguridad se mueve dentro de la ley y la norma. 
Aparecen acuerdos, las fantasías como lo que es real en los juegos, vemos pasar los días, pasa el tiempo, pasamos nosotros, la vida no es lo que pasa, y eso que pasa son minutos, segundos, tiempo o el devenir. Con el patio, el recreo, la clase y el juego detengamos un instante la marcha de la planificación, de la eficiencia, del ganarle a los demás, reflexionaremos sobre el patio y la seguridad. El juego es parte de lo lúdico y es un modo, acción que expresa la representación que el sujeto tiene de ella. En el patio el juego es verdad o mentira y el modo no siempre está presente como formato de juego.

El modo está emparentado por la aptitud, es lo que menos se enseña, es decir, decidir, acción y modo de hacer esa acción. Hay restricciones en el patio y se caracteriza por ser también una libertad supervisada con una dinámica cronometrada sin perder un minuto más para el juego.

Los términos habitantes y sede, en su momento vinieron a licuar las categorías por el sentido común, incluso académico, como alumno, escuela, sus categorías derivadas, escolar, extraescolar, enseñanza y aprendizaje que dificultaban el camino de acceso a la consideración de otras dimensiones del espacio escolar. En este lugar que es la escuela se emparentan con la palabra local en dos sentidos: ser de un lugar "alumno de una época" y estar en el lugar "Profesor hoy en día en la escuela" y analizando las relaciones como describiendo el lugar para un futuro mejor. En ese lugar, se resuelve la vida cotidiana del sujeto, por lo tanto es el patio "lugar" de antes que tiene necesidades de mejorarlo y darle la seguridad que sería muy significativo para la comunidad.

Seguramente todos tenemos la necesidad de un lugar donde reconocernos, esto quiere decir también tener un lugar donde otros nos reconocen. Escuela deriva de skholé, término griego clásico muy próximo al otium latino. Desde la etimología, la escuela puede ser interpretada como un espacio de ocio y por extensión, de recreo. El concepto de ocio entre los ciudadanos de Grecia antigua no es simétrico con el actual, también ocurre con el concepto de vida escolar.

Entre la pausa de vida escolar y los procesos de escolarización contemporánea hay más diferencias que semejanzas. Dentro del contexto escolar aparece el patio donde se desarrollan los juegos con los alumnos y la escuela tiene esos espacios para el descanso como el esparcimiento. En la observación de los patios de las escuelas hay 
cierta preocupación por los continuos cuidados en el lugar de práctica donde los alumnos juegan a distintos juegos. Las presiones, exigiendo la continua atención para la prevención de posibles accidentes es diaria, esa es "la escuela con patio que uno reflexiona en la actualidad".

Históricamente la escuela se fue instalando en un sitio con el objeto de facilitar la enseñanza y el control del alumnado en un espacio protegido, especialmente acondicionado para ese fin.

Sin olvidar la "Reforma", el no prever los patios para la educación física en las construcciones, no sería descabellado pensar en proyectar patios seguros con un diagnóstico, diseño, ejecución y evaluación acorde al contexto.

¿A que invitan los patios de hoy?

Rediseñar los mismos y mejorarlos puede ser una iniciativa muy importante, adecuando el mismo al contexto. Hay que desnaturalizar los discursos, estar con otros, encontrarse con otros, no solamente en educación. Al escenario hay que prepararlo y no sé si hoy se lo piensa como lugar de permanencia para que se queden después. Hay que diseñarlos y prepararlos para el futuro pensando en una mejor educación física con patios seguros.

Al espacio situado lo llamamos sitio, por ejemplo el ubicado en determinado terreno. Quien no recuerda el sitio de aquel juego de la infancia que tanto jugábamos con nuestros compañeros en la escuela. Es el espacio racionalizado, delimitado, por ejemplo por el color, pasto, árboles, alambrados, denominado sector. El espacio productivo se denomina territorio y eso pertenece al mercado. Podríamos mencionar cuatro categorías: el sitio, escenario, sector y lugar.

Retomando los conceptos de norma y de ley en la seguridad de los patios de los profesores de educación física, nos ayudaría a pensar en un inicio de cambios y transformaciones, temas que deben tratarse en profundidad a partir de las manifestaciones públicas de los patios. Volver a mirar los patios olvidados es una tarea pendiente con revoluciones e ideas renovadoras para el interés no sólo del alumno sino también de la comunidad en general. 
En el patio particularmente hay un sinnúmero de problemáticas, pensar en la Argentina seguramente tenemos una larga histórica con respecto a la norma y la ley, dificultades sociales ante problemas que exigen una actitud de cooperación como confianza en los demás. También las relaciones entre los argentinos, las reglas junto con las historias del autoritarismo y dictaduras, como el marcado desprecio por la ley escrita.

Advertir dificultades es importante para coordinar acciones de modo de ponernos de acuerdo quedando el desafío en cada uno de nosotros de reflexionar sobre la relación de las reglas y la identidad. Situarnos en el papel que nunca debimos abandonar como el ser referentes principales de los patios escolares con las mejoras edilicias, es una tarea pendiente. Las referencias básicas propuestas para un "patio seguro en la escuela", debería tener en cuenta las siguientes variables.

- Humanas: aspectos biológicos, psicológicos, sociales.

- Ambientales: aspectos físico naturales, artificiales, políticos, económicos, sociales, culturales, técnicos, etc.

- Específicos: actividades, usuarios y las instalaciones como factor principal.

Planificar las instalaciones y equipo para programas de la educación física recreación y deporte es una tarea pendiente. Es posible observar como distintas formas adquiridas por el espacio escolar, las políticas de construcciones escolares, diseños arquitectónicos, han respondido a los planteamientos concretos de las administraciones educativas. Jugar en los patios de la escuela es jugar en un lugar de libertad vigilada, en un sitio "a la escuela hay que ir" y también una sede "en la escuela hay que permanecer". El poder de lo político y de la política está representado no sólo en el patio sino en el saber y en el hacer.

Al espacio situado lo llamamos sitio, por ejemplo, el ubicado en determinado terreno, quién no recuerda el sitio de aquel juego de la infancia que tanto jugábamos con nuestros compañeros. En los lugares visitados se pueden observar problemáticas en cuanto a la infraestructura edilicia de patios para educación física, en este capítulo muestro gráficos de un distrito con datos relevantes que pueden ser de utilidad. 
En esta tarea de relevar datos de establecimientos educativos podemos observar que establecimientos educativos como escuelas primarias, jardines de educación inicial, centros de educación física, salón de usos múltiples, etc.

¿Qué posición ocupamos los profesores dentro de la escuela y de la sociedad?

Sería interesante saber el lugar que ocupa nuestra educación física como campo del saber y cual en el patio de la escuela.

El patio de juego en la escuela contribuye a la formación integral del niño y promueve su salud psicofísica como casi ningún ámbito. Además la principal actividad de los niños es el juego, que ocupa una gran parte del tiempo del mismo, que también lo ayuda a aprender a enfrentar situaciones complejas y a ejercitar nuevas habilidades.

El juego permite que los alumnos se relacionen con sus pares y tiene un alto nivel creador en el cual los niños desarrollan importantes potencialidades, expresan ideas, sentimientos, fantasías, etc.

La importancia de moverse en el patio sea en la clase o en el recreo es fundamental para el niño en la escuela por lo que debe reunir las condiciones necesarias para permitir los mismos. El patio de juegos constituye una excelente forma de generar incentivos para el desarrollo de los alumnos.

Las caídas y golpes en las prácticas corporales del profesor, en especial en la cabeza constituyen los mayores riesgos asociados a las condiciones del patio y del equipamiento escolar del lugar de práctica de los profesores. Los patios, escenario de nuestras prácticas de la educación física contaminados por paradigmas impropios, nos muestra la realidad de todos los días.

Los patios de las escuelas del distrito observado no tienen en su mayoría instalaciones adecuadas para las prácticas corporales y es deficiente el mantenimiento de su infraestructura. En esta investigación respecto al patio escolar aparecieron distintos problemas vinculados al contexto:

Tras la fallecimiento de un alumno de 14 años en una clase de educación física, la Dirección General de Educación Bonaerense preciso que como parte del control médico que realizan a los chicos, pidan una declaración jurada firmada por los padres, 
en la que figura la historia clínica y si está tomando algún medicamento o padece alguna afección.

En un caso los niños estaban trotando junto a sus compañeros cuando se desplomó uno de los alumnos. Un profesor lo cargo hasta la unidad sanitaria a tres cuadras. Intentaron reanimarlo, pero habría llegado sin vida. La escuela suspendió las clases. Los vecinos reclaman la compra de ambulancia. El niño falleció de un paro cardiorrespiratorio mientras realizaba la clase de educación física en un distrito vecino mientras uno investigaba sobre la responsabilidad civil.

En un medio periodístico se publicaba el preocupante diagnóstico edilicio en las escuelas, un informe de los gremios docentes desnudaba graves falencias. Entre los problemas comunes relacionados con el patio se encontraban:

- Patios con baldosas flojas y baldosas vainillas, mástiles en el centro, columnas de metal o de cemento.

- Perímetro: falta de alambrados, de cercos.

En el mes de Julio del 2006, la municipalidad con autoridades del consejo escolar del distrito del cual investigo organiza una reunión obtener información sobre el estado de la escuelas. El estudio abarcó a los colegios de todos los niveles de enseñanza y fue impulsado por la Dirección General de Escuelas de la Provincia de Buenos Aires.

El área educativa del gobierno bonaerense concretó un estudio similar en todos los distritos de la provincia, teniendo en cuenta que en una segunda etapa sería para el 2007 se llevarán adelante distintas obras vinculadas con la construcción, remodelación y ampliación de los edificios educativos, que permitirán mejorar las condiciones de enseñanza - aprendizaje.

La intención de la provincia se decía es recabar información para luego planificar una serie de inversiones tendientes a mejorar la infraestructura escolar, señalando que los establecimientos educativos de nuestro medio no están en las mejores condiciones edilicias, dado que en la mayoría de los casos se trata de construcciones que tienen muchos años. Manifestando los arquitectos que hay que tener en cuenta que existen muchas casas que han sido transformadas en escuelas, que algunos establecimientos no reciben el mantenimiento adecuado y que, en ocasiones, el uso es inapropiado. 
3. Patios: datos relevados en escuelas de un distrito de la Provincia de Buenos Aires (Argentina)

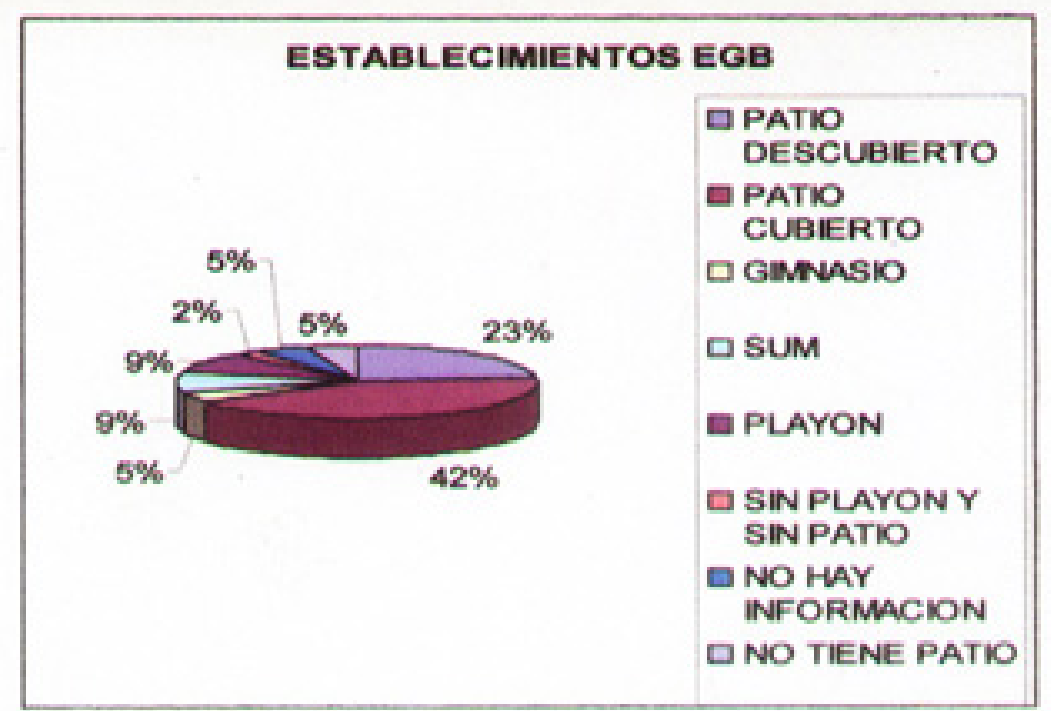

\section{ESTABLECIMIENTOS JARDIN}

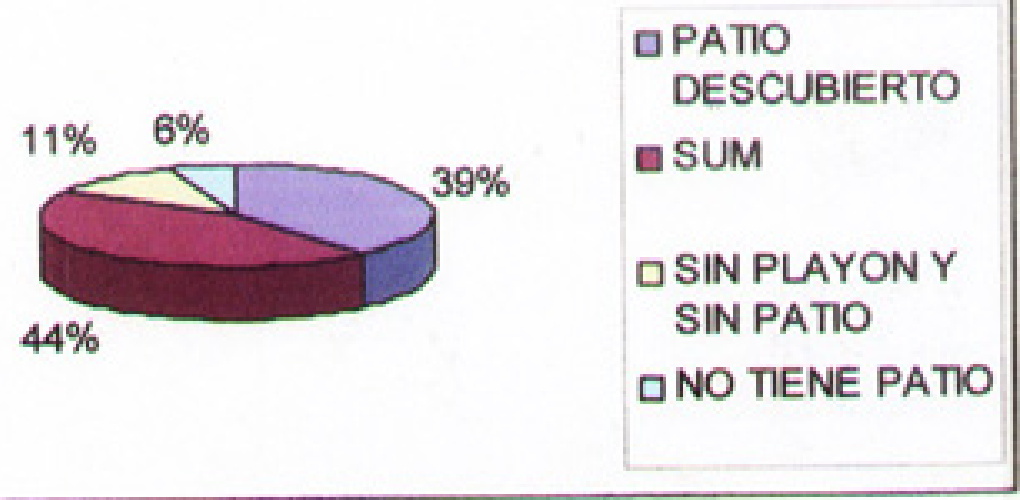




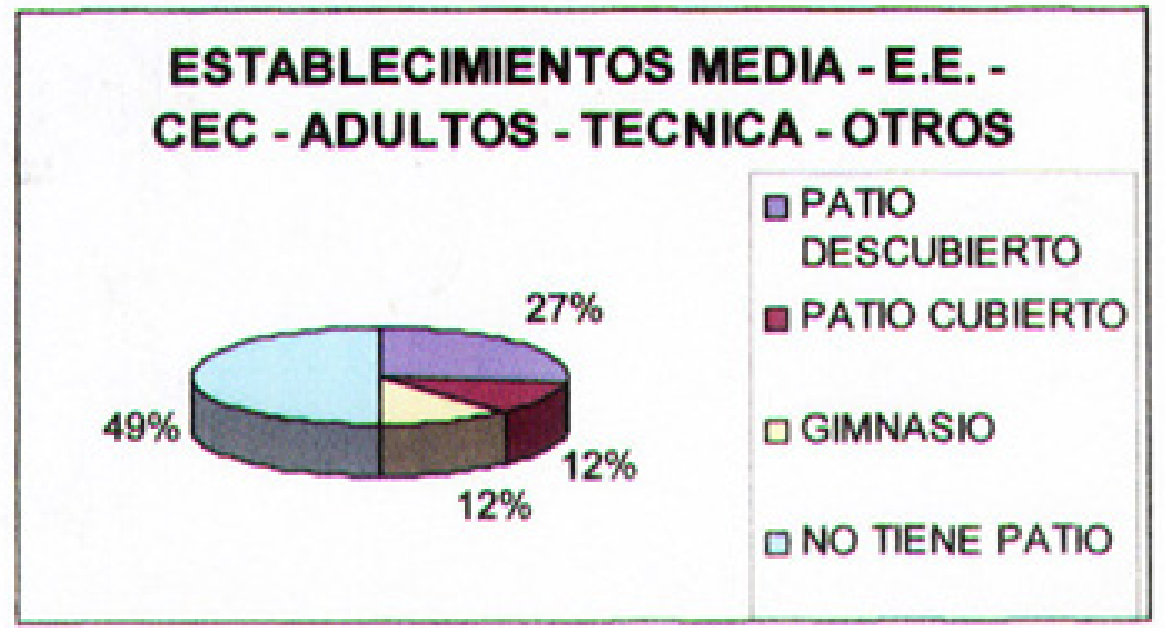

\section{ESTABLECIMIENTOS CEF}

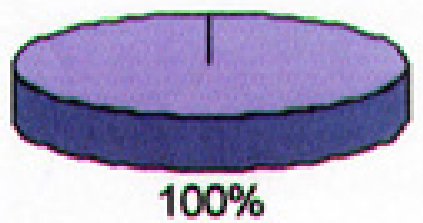

aCON GIMNASIO

Las prácticas sociales, inmersas en espacio y tiempo, se consideran situadas en la raíz de la constitución tanto del sujeto como del objeto social.

En el patio de la escuela las acciones nacen de la aptitud de los individuos para producir diferencias en un estado de las cosas o cursos de sucesos preexistentes. Un agente deja de ser tal si pierde la aptitud de producir una diferencia o sea de ejercer alguna clase de poder. En el espacio de práctica se definen como aptitudes de actores para poner en práctica decisiones preferidas por ellos, por un lado y la movilización de influencias inherentes a la institución por el otro. 
El poder en sistemas sociales que disfrutan de cierta continuidad en tiempo y espacio presupone relaciones regularizadas de autonomía y dependencia entre actores o colectividades en contextos de interacción social. Aparecen las reglas que denotan por un lado la constitución de sentido y por otro, la sanción de modos de conducta social. Las apariciones de las reglas son denominados procedimientos de acción, como aspectos de una praxis, comprendiendo un lenguaje los alumnos significa que los profesionales dominan una técnica.

Un patio en el cual podemos decir que entender el procedimientos o dominar una técnica de hacer actividad social, es por definición metodológica entender las situaciones con las que un actor se puede encontrar, que proporciona la aptitud generalizada de responder a un espectro indeterminado de circunstancias sociales y de influir sobre este. Los tipos de reglas más significativos en la teoría social se alojan en la reproducción de prácticas institucionalizadas.

La mayor parte de las reglas que intervienen en la producción y reproducción de prácticas sociales son aprehendidas sólo tácitamente por los actores.

\section{Estructura}

Reglas y Recursos, o conjuntos de relaciones de transformación que se organizan como propiedades de sistemas sociales.

\section{Sistema}

Relaciones reproducidas entre actores o colectividades, organizadas como prácticas sociales regulares

\section{Estructuración}

Condiciones que gobiernan la continuidad o trasmutación de estructuras y, en consecuencia, la reproducción de sistemas sociales. 
Analizar los patios dentro la estructuración de sistemas sociales significa estudiar los modos en que esos sistemas, fundados en las actividades inteligentes de actores situados que aplican reglas y recursos en la diversidad de contextos de acción, son producidos y reproducidos en una interacción.

El fluir de las distintas acciones producen consecuencias no buscadas por los actores y estas no buscadas podrían dar origen a condiciones inadvertidas de la acción en un proceso de realimentación. Si bien la educación física es una modalidad en la ley podríamos analizar un cuadro en la cual lo profesionales de la educación corporal en el lugar de trabajo no serían capaces de registrar sus actividades, por lo que necesitaríamos comprender los modos de las prácticas.

\begin{tabular}{|l|l|l|l|}
\hline estructura & significación & dominación & legitimación \\
\hline modalidad & $\begin{array}{l}\text { esquema } \\
\text { comprensión }\end{array}$ & facilidad & norma \\
\hline interacción & comunicación & poder & sanción \\
\hline
\end{tabular}

Si hablamos de responsabilidad del profesional en el patio en su acepción cotidiana expresa con justeza los esquemas interpretativos y de normas, ser responsables de las actividades en tanto explicar las razones de ellas como ofrecer los distintos argumentos normativos que las puedan justificar. Los componentes normativos se centran en las relaciones entre los derechos y las obligaciones que se esperan de quienes participan en el contexto de las interacciones.

Los códigos formales de conductas, como el estatuto y el código civil, están presentes entre los derechos y obligaciones, donde los unos son la justificación de otros. Cada individuo tiene el derecho, cuyo contenido varía bajo múltiples aspectos en contextos diferentes, de mantener distancia de otros en la que preserve una privacidad corporal y una integridad propia.

El concepto rutina en el patio, fundado por una conciencia práctica, es vital para la teoría de estructuración. Es inherente tanto a la continuidad de los agentes en el patio escolar, en las actividades cotidianas, cuanto a las instituciones de la sociedad, que son tales en virtud de la reproducción continuada. 
Un análisis de las rutinas nos proporciona una llave para explicar las formas características de relación entre el sistema de seguridad básica, por un lado, lo procesos constituidos reflexivamente, el carácter episódico de encuentros, por el otro.

Las reglas que se aplican reflexivamente en circunstancias de co presencia nunca se limitan en sus alcances a encuentros específicos sino que se aplican en la reproducción del diseño de encuentros a través de un tiempo y un espacio. Los actores sociales se pueden equivocar algún tiempo sobre lo que esas reglas y tácticas sean, y en esos casos sus errores pueden aparecer como inconvenientes situacionales. Existen diferencias potenciales entre entender las reglas y tácticas de una conducta práctica en los medios donde el agente se mueve y entender aquellas que se aplican en contextos distantes de su experiencia.

Si hablamos de la normativa legal vigente, es importante comprender que, normal no equivale a perfecto, se puede demostrar que el decir normal es imperfecto. Pero el cumplimiento de la norma es esencial su accionar en la postura de los actores en contexto del patio escolar, pensando también en torno a los modos en que los sistemas sociales se constituyen por un espacio - tiempo. Según señale antes, sobre la investigación la responsabilidad civil es temporal y espacial por lo que no se puede pasar por alto ni omitirla.

Los encuentros que los individuos tienen en la trayectoria de la vida escolar en el patio están sujetos a restricciones que derivan en el cumplimiento de las normas escolares. Los proyectos que se tratan de realizar, para ser puestos en acto, tienen que utilizar los recursos limitados de tiempo y espacio, a fin de superar las restricciones a que se enfrentan. No obstante, existen discrepancias entre comunidades sociales y en el interior de ellas por referencia a las restricciones de movilidad y comunicación que afectan a diferentes grupos e individuos.

Si hablamos del patio como lugar, no se puede emplear en teoría social simplemente para designar el punto en el espacio, como tampoco hablar de puntos en el tiempo como sucesión de ahora. El concepto de sede y de disponibilidad de presencia como están implícitos en las relaciones entre integración social y sistémica, sede denota el uso del espacio y para proveer los escenarios de interacción y a su vez los escenarios de interacción son esenciales para especificar su contexto. 
Regionalización no se debe entender sólo como localización en el espacio sino como referida a la zonificación de un espacio - tiempo en relación con prácticas sociales. El estar juntos en el patio escolar de la co presencia exige medios que permitan a los actores coincidir. No hay duda que trazar el mapa de las pautas espacio - temporal que siguen alumnos, maestros, profesores en la escuela es un artificio topológico útil para iniciar el estudio de esa escuela.

En tanto la escuela donde se encuentra el patio de educación física es un tipo de organización social que se concentra en un local que posee precisas características físicas, sus características se pueden entender por referencia a tres aspectos: la distribución de encuentros que se producen en su interior por un tiempo y un espacio, la regionalización interna que muestra y la contextualizad de las regiones así individualizadas.

En general, la distribución de encuentros en el interior de una escuela presenta un vivo contraste con sectores de vida social en que la regulación normativa de la actividad es diferente. La fijación de espacios disciplinarios forma parte del carácter arquitectónico de las escuelas, tanto en la separación de los espacios, el esparcimiento de mobiliario, las divisiones espaciales, el lugar del patio escolar como también la distribución de otros espacios.

Los rasgos contextuales de los patios de las escuelas nos muestran las principales áreas de aplicación de poder en cada una de ellas, presentando una amplia variación. Las distintas aulas como las escuelas son contenedoras de poder, una disciplina vigilada en un medio poderoso de generar poder, pero depende sin embargo, del acatamiento más o menos continuo.

Se pueden hacer visitas regulares a las escuelas para verificar su funcionamiento, acaso hagan sentir su poder para influir en los cursos de acción o para priorizar la construcción de determinada aula escolar. Las nuevas técnicas de poder conectan sin mediación disciplina con utilidad.

El control del cuerpo forma parte de la novedosa "anatomía política" y en tanto tal, dice Foucault, aumenta el producto del cuerpo al mismo tiempo que reduce su independencia de orientación. 
La disciplina no tienen otro camino que el de manipular un tiempo y un espacio, requiere de un cerco, una esfera de operación clausurada y cerrada sobre sí misma.

Un análisis institucional, es un análisis social que pone en suspenso las destrezas y la conciencia de cada uno de los actores para considerar las instituciones como reglas y recursos reproducidos. Los patios del distrito de cada escuela necesitan ser analizados desde la perspectiva de cumplir con las pautas mínimas para garantizar seguridad, adecuados a las prácticas del profesional de la educación física y ser el lugar ideal de encuentros social y cultural del tiempo para la recreación, el juego, los eventos sociales, etc. 


\section{Capítulo II}

\section{La Responsabilidad Civil y la Escuela.}

En el capítulo anterior se abordó el tema de los patios de las escuelas, su estado actual y las distintas referencias. Los contextos y los datos relevados de un distrito permitieron ir conociendo el estado actual. El siguiente capítulo ingresaremos en los temas de la responsabilidad civil como las obligaciones del propietario con sus normativas.

\section{La Responsabilidad (Significados).}

Cotidianamente utilizamos la palabra responsabilidad y le atribuimos un sin número de significados que no siempre aplicarse con igual extensión o sentido. A eso debe agregarse que cada manifestación de nuestra conducta admite ser considerada desde la óptica de si uno es o no es responsable en el patio escolar. La idea de responsabilidad en su acepción cotidiana expresa con justeza la intersección de esquemas interpretativos y de normas.

Continuando con el estado actual de los patios escolares, lugar de trabajo del profesional, donde varían los contextos, en la cual las circunstancias, el tiempo y el espacio son diferentes al ser relevados datos de distintas escuelas del distrito aumentaría la problemática de la responsabilidad.

Por tal motivo ser responsable el profesional de las propias actividades es tanto explicar las razones de ellas como ofrecer los argumentos normativos que las puedan justificar. Componentes normativos de interacción se centran siempre en relaciones entre los derechos y las obligaciones que se esperan de quienes participan en un espectro de contextos de interacción.

Responsabilidad Civil definida por Bustamante Alsina, como el deber de dar cuenta a otro del daño que se le ha causado. Dicha reparación consiste en una indemnización o resarcimiento de carácter económica. No tiene como finalidad sancionar sino determinar si la persona demandada debe compensar económicamente a quien sufrió algún tipo de daño. 
La Responsabilidad Civil se traduce en la obligación de reparar los perjuicios ocasionados indebidamente a otros, en las personas o en las cosas, a través de una indemnización que consiste en retornar las cosas al estado anterior en el cuál se encontraban, o en caso de imposibilidad o elección del damnificado, mediante un pago en dinero. Por lo tanto, para incurrir en esta clase de responsabilidad debe surgir de nuestra actividad un perjuicio patrimonial o extra patrimonial. Sin daño producido no hay responsabilidad civil.

La responsabilidad importa un deber que, como respuesta adecuada, soporta quien ha causado un daño, perjuicio o detrimento. El responsable tiene que indemnizar a la víctima, la responsabilidad enfrenta a una pareja con intereses opuestos: víctima y victimario; dañado y dañador; a quien padece el perjuicio y a quien es agente del mismo. La idea de responsabilidad conlleva una lectura de la actividad que se despliega en el ejercicio de una determinada tarea de educación física. Por lo tanto, cuando la aplicamos a la problemática educativa circunscribimos el campo de lectura a las tareas que se desarrollan dentro del Sistema Educativo Provincial.

Podemos distinguir según cuál sea el tipo de norma que fija los límites de la misma. Desde ese punto de vista, se pueden considerar tres aristas de responsabilidad. La responsabilidad civil, administrativa y penal. Para que se sostenga la existencia de responsabilidad civil se debe contar con cuatro presupuestos que son el daño, la antijuridicidad, el nexo causal y el factor de atribución. Si no se configura tan sólo uno de esos elementos la responsabilidad no existe.

El daño, es una lesión, ofensa, disminución ocasionada a un sujeto en sí mismo, en sus bienes o en sus sentimientos.

La antijuridicidad es un acto contrario al derecho objetivo, considerado en su totalidad.

El nexo causal es la relación de carácter objetivo y que se debe hacer sobre la base de la apreciación de la regularidad de las consecuencias, entre el daño y le hecho generado. 
El factor de atribución es la razón que determina la obligación de reparar el daño causado. Para determinar el factor de atribución debemos preguntarnos, ¿cuál es el motivo por el cual se debe responder?

Lo que caracteriza a este tipo de responsabilidad es que el castigo se explicita en la obligación de devolver las cosas al estado en que se encontraban antes que la acción u omisión provocaran los daños. Es decir, aparece lo que se llama la obligación de indemnizar.

La etimología de indemnizar nos lleva a indemne, mantener indemne o "entero". En otras palabras, volver las cosas al estado en que se encontraban antes, significa arreglar, reparar. Hay lesiones en las prácticas de las clases de educación física cuya curación no es total ni definitiva y conllevan largos tratamientos o discapacidades físicas permanentes. No es lo mismo una fractura de tobillo, sin secuelas, que una que produce acortamiento del miembro lesionado con carácter irreversible y por lo tanto, definitivo y permanente.

Un denominador común se utiliza para medir la responsabilidad: el valor en dinero de las consecuencias dañosas de la acción y omisión. Ese valor, que varía según el tipo de lesión y de secuelas se denomina indemnización.

Es un tema de suma importancia, y el que merece un tratamiento especial, dado que actualmente se promueven demandas judiciales por esta causa, razón por el cuál se entiende que resulta necesario el esclarecimiento de conceptos, o bien para evitar dichos juicios mediante la prevención, o bien para saber proceder en caso de enfrentar tales situaciones. Cuando mayor sea el deber de obrar con prudencia y pleno conocimiento de las cosas, mayor será la obligación que resulta de las consecuencias posibles de los hechos.

Por ello, los directivos y profesores deben seguir trabajando con el sentido de responsabilidad que los caracteriza, haciendo hincapié en la prevención. El funcionamiento del servicio educativo, brindando orientación e instrucciones para el desenvolvimiento de las tareas durante la jornada escolar, lecciones paseo y actividades conexas. 
También efectuará un seguimiento para verificar el cumplimiento de sus indicaciones y el ejercicio por parte de los docentes de las funciones que le son propias con la responsabilidad y eficacia que el rol exige.

Se parte de la idea de los daños como un mal, un desvalor o contravalor, algo que se padece con dolor, puesto que nos achica o reduce; nos quita algo que era nuestro, de lo cual gozábamos o nos aprovechábamos, que era nuestra integridad psíquica o física, las posibilidades como persona humana, cosa sagrada, o bien el uso y disfrute de los bienes que componen nuestro patrimonio, que van unidos a las posibilidades de acrecentamientos o nuevas incorporaciones. Por otro lado vivir en sociedad, vivir honestamente, la conducta dañadora se muestra como impropia, equivocada o ilícita.

El ordenamiento jurídico declara de manera expresa las diferentes responsabilidades. Es verdad que teniendo una paz social y de vida armónica no hay que desterrar las conductas dañosas; que la vida en sociedad nos exige en la convivencia soportar algunos daños; como también perjuicios justificados en su producción.

No hay responsabilidad sin una conducta del autor y agente, contraria al ordenamiento jurídico, atribuibles al factor objetivo o subjetivo, que originan daño en relación de causalidad adecuada. La reacción del ordenamiento consiste en una sanción procedente a pedido de la víctima, que tiende al resarcimiento o reparación del perjuicio. A la vuelta al estado anterior, borrando el daño, con sanción específica, indemnizándolo con una suma de dinero, sanción sustitutiva. Las cosas no fueron siempre así, sin dudas el tema responsabilidad civil, antes y después de la reforma del año 1968, ha provocado inquietud e interés. La responsabilidad civil de los propietarios de establecimientos educativos privados o estatales como también de los Directores y de los Profesores no hay que dejar de analizar en su totalidad.

Si no se contemplasen los hechos que ocurren o pudiesen llegar a suceder, se convertiría en mera prescripción vacía de contenido, pues es importante reglamentar las conductas que se desenvuelven en la sociedad. Los sistemas legales por años fueron sometidos a cambios, ocurriendo frecuentemente a causa de los contantes progresos. El derecho es social, abarca la realidad desde los planos correspondientes. 
Lo normativo no es extraño a lo social, ambos comparten un espacio en común. Las normas jurídicas, morales y religiosas integran la sociedad humana, con obligaciones y derechos respecto a grupos societarios. No hay sociedades sin normas, sean estas jurídicas, morales o religiosas. Son un auxilio para la paz y para la convivencia, no se pueden desconocer ya que si no traen aparejada una sanción dentro del orden jurídico.

Todo sistema de la responsabilidad civil se fundamenta primordialmente en la culpa y es requisito ineludible que la acción u omisión de una persona produzca un perjuicio patrimonial o extra patrimonial a otra. Dos son los requisitos de la responsabilidad civil: en la victima el sufrimiento de un daño y en el autor de la acción u omisión: culpa, dolo o responsabilidad objetiva atribuida por la ley "teoría del riego creado".

El derecho es cultura, es el deber ser que limita la libertad y no el ser que para nada la restringe. La vida social es una realidad ineludible, no puede subsistir fuera de la vida social. Ello es posible en el orden, por lo que donde hay convivencia debe haber un cierto orden que se sobrepone a lo individual. Los daños ocasionados deben ser reparados, resarciendo los perjuicios ocasionados a terceros o a las cosas. El daño para ser reparado, debe ser cierto, ya sea presente o futuro y además subsistente.

La concurrencia de alumnos a los patios escolares en las clases de educación física es mucha y sin poder prever las consecuencias de las actividades pueden perjudicar a ellos, a otros o a terceros. Todas las circunstancias determinan la necesidad de un estudio profundo. Analizar desde distintos ángulos el patio escolar, la responsabilidad civil de quienes por negligencia o culpa pueden descuidar los deberes de educación, la vigilancia o la dirección que tienen sobre los alumnos a su cargo es más que una tarea pendiente.

La relación entre el maestro y el alumno ya es un hecho jurídico que pone al docente a cargo del primero y la obligación legal de vigilancia sobre el último. Dicha vigilancia debe ser medida según la cantidad de alumnos que tenga a su cargo en el establecimiento educacional. La delegación del director sobre el profesor en el cuidado de los alumnos, la realidad de los patios escolares en las horas de educación física puede ocasionar problemas legales de no actuar con prevención. 
La falta de prudencia, imprudencia temeraria, negligencia con olvido de las precauciones aconsejadas lleva a realizar hechos, que el autor ejecutara maliciosamente, sería delito. Quienes obran con prudencia, que no tienen falta de cuidado o de aplicación ven con antelación y son previsores. Preparar con anticipación a fin de impedir un riesgo o para efectuar una acción son los que advierten que conocer los principios legales como también observan todos los cuidados que correspondía a su deber.

Para que la Dirección General de Cultura y Educación, se haga cargo, el alumno debe encontrarse "bajo la vigilancia" del profesor de educación física en el patio escolar, por consiguiente, cuando la vigilancia falta, el estado no sustituye al profesor. Para eximirse de responsabilidad se debe probar "la imposibilidad" en que se hubiese estado de impedir el hecho dañoso.

La práctica de la educación física en los patios no es riesgosa por su naturaleza, pues se ejerce de diversos modos y en diferentes sitios. Es una práctica social que se convierte en riesgosa por las circunstancias de su realización. La responsabilidad civil se traduce en la obligación de reparar los perjuicios ocasionados indebidos por otros en la persona o en las cosas, a través de una indemnización que consiste en volver las cosas al estado anterior en cual se encontraban o en caso de imposibilidad o elección del damnificado, mediante el pago en dinero.

No basta la existencia del contrato y el daño ocurrido al alumno en el patio escolar para poderlo encuadrar dentro de la responsabilidad contractual. Para ello hace falta concluir en que el contrato incluía como obligación a cargo del establecimiento la de velar por la seguridad de los alumnos, de manera de que regresen sanos y salvos de las clases de educación corporal. Si no estuviera contemplada en el contrato, el resarcimiento del accidente ocurrido al alumno debería buscarse en el terreno de lo extracontractual, del acto ilícito. El difícil concebir actualmente que los representantes legales al celebrar un convenio de educación no tengan en cuenta la seguridad del alumno. 
El alumno debe estar protegido en el patio en todo sentido y más cuando se lo está educando. Es indudable que los alumnos están sometidos a diversos riesgos en la vida cotidiana, pueden estar más expuestos al peligro de acuerdo a las circunstancias, tiempo y lugar en la escuela. Recordar que una menor de seis años a modo de ejemplo no posee una comprensión de lo peligroso como presuntamente tiene alguien mayor de edad.

\section{Responsabilidad civil en las prácticas del Profesor.}

Las prácticas que se desarrollan en las escuelas, en el patio de educación física involucran la participación de muchos actores, entre ellos el personal directivo, los docentes, los administrativos, porteros y cientos de personas que concurren diariamente a la institución cuyo propietario resulta, en principio, responsable de la seguridad de todas ellas. Esta situación se torna aún más delicada cuando los patios que se encuentran en no muy buenas condiciones y se trata de cuestiones que involucran a menores de edad. La ley considera que éstos, se encuentran bajo el régimen de "guarda educacional" por lo que exige el cumplimiento por parte del "guardador" de obligaciones específicas tales como deberes de cuidados y vigilancia activa de todo menor.

Merece un particular análisis la responsabilidad tanto en el establecimiento educativo donde el profesor trabaja, en el patio, resultando valioso detenerse en la interpretación del artículo 1.117 del Código Civil.

Respecto al nuevo artículo 1.117 del Código Civil, reformado en el año 1997, limita la responsabilidad civil de los docentes. Con esta reforma producida los docentes no obtuvieron aún, quizás por desconocimiento, la "tranquilidad" de no responder con su propio salario o patrimonio, dado que el cambio implica trasladar la responsabilidad a los propietarios de las escuelas, (entendiéndose dueños en el caso de establecimientos privados, y de los gobiernos en el caso de las escuelas públicas).

En el caso de acusación de negligencia al profesor de educación física en su accionar en el patio, deberá seguir una vía administrativa sumarial, iniciada por sus superiores. En la actualidad quién demande al propietario de un establecimiento, tendrá que probar la negligencia del docente, y no como era el sistema anterior a la reforma en la que el docente debía probar que había obrado con la debida diligencia. 
Con la reforma se producen dos grandes cambios importantes

1) El actual responsable no es el docente sino el propietario del establecimiento.

2) En que demande al propietario del establecimiento debe probar la negligencia docente, eliminándose la presunción de culpabilidad que recaía sobre el docente, quién antes debía probar que habría obrado con la diligencia debida.

La mencionada norma es de aplicación únicamente en aquellas entidades que tengan como finalidad principal la educación. Es importante para el profesor de educación física en sus prácticas que cuando un menor ingresa al establecimiento educativo, la posibilidad de cuidado y vigilancia real de sus padres queda restringida. En el tiempo que permanece en la escuela en su ámbito los deberes - derechos de cuidarlos y educarlos quedan a cargo de la institución. Podemos decir que existe una verdadera delegación de la guarda al establecimiento, quién asume las responsabilidades que esta situación trae aparejada.

La responsabilidad de los padres cesa cuando el hijo ha sido colocado en un establecimiento de cualquier clase y se encuentra de una manera permanente bajo la vigilancia y autoridad de otra persona. Hay un desplazamiento de la guarda del hijo que ejercen los padres para con el colegio. Es importante tener en claro que en esta circunstancia constituye una de las causas principales que originan la responsabilidad del colegio por los daños sufridos u ocasionados por los alumnos. En el caso de personas que pretende reclamar por daños que un alumno le ocasionó en la clase del patio de educación física, por ejemplo: el menor arrojó por la ventana del colegio una piedra y le produjo una lesión. Esta persona tendrá dos alternativas:

a) demandar al propietario de la escuela.

b) demandar al profesor que estaba a cargo del alumno al tiempo del hecho.

Si elige la opción "a" tiene las siguientes ventajas: solo tiene que demostrar la producción del hecho (que el alumno en horas de clase y en el colegio ocasionó el daño) y el perjuicio sufrido. Existe presunción de culpa del propietario, quién para liberarse de su responsabilidad deberá probar "caso fortuito". La ley obliga al 
propietario del establecimiento educativo a contratar un seguro por lo que la solvencia del demandado estaría garantizada y el cobro de la indemnización asegurado.

Si elige la opción "b" el damnificado deberá: probar la ocurrencia del hecho, el perjuicio y la negligencia del docente o director del colegio en su deber de vigilancia del alumno. En este caso, si el damnificado no prueba que hubo negligencia por parte del docente el reclamo sería rechazado. Al profesor le bastará por acreditar que obro con la debida diligencia aunque no haya podido evitar el hecho para eximirse de responsabilidad.

La solvencia de un docente, por lo general no es la misma que la de los propietarios de establecimientos educativos, el estado o la compañía aseguradora. El damnificado podría obtener una sentencia favorable por el reclamo y el cobro de la indemnización. Ante un perjuicio ocasionado por el alumno, el damnificado tratará de perseguir el resarcimiento económico demandado por artículo 1.117 del Código Civil al propietario, no obstante no se puede descartar el reclamo al docente o a ambos al mismo tiempo.

Cuando mayor sea el deber de obrar con prudencia y pleno conocimiento de las cosas, mayor será la obligación que resulte de las consecuencias posibles de los hechos. Vigilar a los alumnos con la correspondiente atención sobre los menores a cargo para que no les sobrevengan ni causen daños dentro del patio escolar es obrar con prudencia y pleno conocimiento. Tener mucho cuidado en el ámbito escolar cuando hallamos educandos que desaprensivamente pueden ocasionarse daños en los juegos que se realizan, en actividades gimnásticas o de vida al aire libre como también en otro tipo de prácticas que habitualmente se desarrollan en los patios que difunden educación. Solo cesa la responsabilidad si probaren que no pudieron impedir el daño con la autoridad que su calidad les confería y con el cuidado que era de su deber poner.

Poseer mayor conocimiento de los riesgos y peligros, actuar con diligencia y responsabilidad en los juegos, deportes, recreación, labores normales en el patio. Recordar que el que ejecuta un hecho, que por su culpa o negligencia ocasiona un daño a otro, está obligado a la reparación del perjuicio. Vigilar a un alumno no significa ejercer "autoritarismo" sobre él, sino mantener el orden para que la clase se desenvuelva en convivencia y armonía haciendo posible la enseñanza. Pensar que en educación, brindar las prácticas en su esencia y sea adquirida por el alumno con plenitud es indispensable un mínimo de vigilancia, sea en educación física, en danzas, en teatro, en el cine, etc. 
Plantearnos muchos interrogantes no es un pretexto sino que tiene un verdadero interés práctico, pues el sistema de la responsabilidad civil de una y otra relación es diferente como también las consecuencias que se derivan de la aplicación práctica. La vigilancia cesa cuando el alumno no se encuentra en el horario de educación física y pasa a manos de la maestra como también cuando sale del establecimiento escolar a la hora indicada para ello. Cuando el profesor se encarga de la conducción de los alumnos más allá de los límites de su terreno, esa obligación de vigilancia aún se mantiene.

La autoridad escolar está obligada a reintegrar a la salida de cada jornada escolar, sano y salvo, al alumno ya que las obligaciones de guarda, vigilancia y seguridad están incluidas dentro de los deberes de dicha autoridad. El profesional en la escuela tiene como obligación desempeñar digna, eficaz y responsablemente las funciones inherentes al cargo. También tener conocimiento, respeto y cumplimiento de las normas legales vigentes. Cumplir con las normativas que se dicten para la mejor organización y gobierno de la enseñanza-aprendizaje. Declara bajo juramento el cargo y/o actividades oficiales o privadas, actualizando su domicilio en la repartición donde preste los servicios, el que subsistirá a todos los efectos legales, mientras no denuncie otro nuevo. El profesor de educación física imparte y guía la educación de los alumnos en el patio escolar dirigiendo u orientando la enseñanza en cualquier nivel, modalidad y especialidad.

\section{Obligaciones de Propietarios.}

El abordaje de la responsabilidad civil de los distintos componentes de la comunidad educativa (titulares de establecimientos, directivos y docentes), ha variado sustancialmente por la modificación del artículo 1.117 del Código Civil por la Ley 24.830. La citada norma fue publicada en el Boletín Oficial el 7 de Julio de 1997.

\section{Artículo 1.117 Código Civil - texto Ley 17711 Redacción original}

Lo establecido sobre los padres rige respecto a los tutores y curadores, por los hechos de las personas que están a su cargo. Rige igualmente respecto de los directores de los colegios, maestros artesanos, por el daño causado por sus alumnos o aprendices, mayores de diez años y serán exentos de toda responsabilidad si probaren que no 
pudieron impedir el daño con la autoridad que su calidad le confería y con el cuidado que era su deber poner.

\section{Artículo 1.117 Código Civil texto actualizado por Ley $\mathbf{2 4 . 8 3 0}$ Vigente a la fecha.}

Los propietarios de los establecimientos educativos privados y estatales serán responsables de los daños causados por los alumnos menores de edad, y por los daños sufridos por dichos alumnos por incumplimiento de la obligación, de seguridad producidos durante el desarrollo de toda actividad escolar, extraescolar o complementaria, cualesquiera sean día, la hora y el lugar en que se produzca un daño, pudiendo eximirse exclusivamente probando el caso fortuito externo. Los establecimientos educativos deberán contratar un seguro de responsabilidad civil emergente de este artículo.

\section{Artículo 1.109.}

Todo el que ejecuta un hecho, que por culpa o negligencia ocasiona un daño a otro, está obligado a reparación del perjuicio. Esta obligación es regida por las mismas disposiciones relativas a los delitos del D. Civil.

\section{Artículo 1.112.}

Los hechos y las omisiones de los funcionarios públicos en el ejercicio de sus funciones, por no cumplir sino de una manera irregular las obligaciones legales que le están impuestas, son comprendidos en las disposiciones de este título.

\section{Artículo 1.113.}

Las obligaciones del que ha causado un daño se extiende a los daños que causaren los que están bajo su dependencia, o por las cosas de que se sirve, o que tiene a su cuidado. En los supuestos de daños causados con las cosas, el dueño o guardián, para eximirse de responsabilidad, deberá demostrar que de su parte no hubo culpa, pero si el daño hubiere sido causado por el riesgo o vicio de la cosa, sólo se eximirá total o parcialmente de responsabilidad acreditando la culpa de la víctima o de un 
tercero por quién no debe responder. Si la cosa hubiese sido usada contra la voluntad expresa o presunta del dueño o guardián, no será responsable.

\section{Artículo 1.115.}

La responsabilidad de los padres cesa cuando el hijo ha sido colocado en un establecimiento de cualquier clase, y se encuentra de una manera permanente bajo la vigilancia y autoridad de otra persona.

\section{Artículo 1.116.}

Los Padres no serán responsables de los daños causados por los hechos de sus hijos, si probaren que les ha sido imposible impedirlos. Esta imposibilidad no resultará de la mera circunstancia de haber sucedido el hecho fuera de su presencia, si apareciese que ellos no habían tenido una vigilancia activa sobre sus hijos.

\section{Artículo 1.118.}

Los dueños de hoteles, casas públicas de hospedaje y de establecimientos públicos de todo género, son responsables del daño causado por sus agentes o empleados en los efectos de los que habiten en ellas, o cuando tales efectos desapareciesen aunque prueben que les ha sido imposible impedir el daño.

A partir de la modificación legislativa ya no se presume la culpa de los directores de las escuelas y si se atribuye la responsabilidad al titular del establecimiento educativo al que concurre el alumno. Será entonces la persona física o jurídica, tanto privada como pública que detente el carácter de propietario de la institución a la que asista el alumno dañador o damnificado, quién resulte ser el legitimado para iniciar la acción resarcitoria.

Sin perjuicio de lo antes expuesto, no se encuentran exceptuados los directivos o maestros quienes pueden ser responsabilizados en forma directa si se demuestra su dolo o culpa, y en tal caso, deberán reparar el daño causado de acuerdo a los principios generales de responsabilidad civil subjetiva (art. 1.109 del Código Civil), en este supuesto la responsabilidad es concurrente con la del titular del establecimiento. 
Los daños causados por los alumnos a terceros, en este supuesto responde siempre el titular del establecimiento, sea que se hubiere dañado a terceros extraños o alguien vinculado con la actividad educativa (alumnos, docente y / o persona que por alguna causa estuviere en la escuela, o transeúnte, etc.).

Los daños sufridos por los alumnos, siempre por el daño que sufran el menor, sea causado por un dependiente, un tercero ajeno, un alumno, o por el hecho de cosas, siempre que ocurran el evento dañoso durante actividades realizadas bajo el control de la autoridad educativa, por incumplimiento de la obligación de seguridad.

\section{Requisitos para que resulten responsables los titulares del Establecimiento Educativo}

La edad del menor, estarían comprendidos en la norma los daños causados o sufridos por cualquier menor, aún los menores de 10 años y hasta 21 años, donde se adquiere la mayoría de edad. En la actividad escolar el daño puede ser físico o moral, debe producirse mientras el menor se encuentre bajo control de la autoridad educativa.

A tal efecto tal hipótesis comprende toda actividad estrictamente curricular, la que se extiende a todas las que se vinculen a ella por el hecho de encontrarse organizadas y controladas por la autoridad educativa (o a través de sus dependientes, directores, docentes en general, preceptores, etc.), no se limita a actividades desarrolladas en aulas, se incluye por ende, las deportivas, viaje de estudios o recreación, etc. Con lo cual los directivos y docentes de las escuelas tienen que cumplir con su obligación de vigilancia respecto del alumnado en un límite temporal muy amplio. El nivel de enseñanza, se limita la reparación al titular de escuelas de ciclos inicial, educación general básica, educación poli modal. Quedando expresamente exceptuado la enseñanza terciaria y universitaria.

\section{Eximentes de Responsabilidad.}

El titular deberá probar el caso fortuito, conforme al artículo 514 del Código Civil, a fin de no tener responsabilidad sobre el hecho ocurrido.

\section{Propietarios.}


De Gestión Pública: La Dirección General de Cultura y Educación de la Provincia de Buenos Aires.

De Gestión Privada: La orden confesional, sociedad civil sin fines de lucro, sociedades comerciales (sociedades anónimas, sociedades de responsabilidad limitada, sociedades cooperativas, sociedades de hecho, emprendimientos unipersonales, etc.) que figuren como propietarios de los establecimientos debidamente reconocidos en el marco de la normativa.

De los daños causados por los alumnos menores de edad, cualquier daño (físico o psíquico, total o parcial, a las personas o a las cosas, permanente o transitorio) que puedan ocasionar los alumnos a terceros o cosas de terceros ajenos al establecimiento.

De conformidad con la legislación civil vigente se entiende por menor de edad el que no alcanzó los 21 años de edad. De modo que desde el nivel inicial (que conformidad con la ley 11.612 es comprensivo del jardín maternal hasta la sala de 5 años incluida artículo 4 inciso a) de la citada Ley hasta el nivel superior los hechos que los menores de 21 años produzcan y conlleven daños a terceros quedan comprendidos en la responsabilidad civil a cargo del propietario del establecimiento. El daño conlleva la obligación de su reparación volviendo las cosas al estado en que se encontraban antes de que se produzcan y de no ser ello posible indemnizado pecuniariamente sus secuelas.

Por incumplimiento de la obligación de seguridad: Se entiende por tal conductas esperables de los agentes del sistema que, prestando servicios en un determinado servicio educativo y en estricto cumplimiento de la normativa vigente en materia de reglamento general de escuela públicas y las consiguientes disposiciones de cada una de las ramas y modalidades, se adecuan a esa normativa aplicada al perfil de la institución.

Adquiere fundamental relevancia a los efectos de la determinación de los alcances prácticos de esa "obligación de seguridad" el diagnóstico institucional y el mapa de riesgo que, como parte integrante del proyecto institucional permitirá entender los acuerdos que la comunidad educativa de esas escuelas celebran en pos del mejor cumplimiento de esa obligación. 
Durante el desarrollo de toda actividad escolar, extraescolar o complementaria, debe entenderse en un sentido amplio.

Escolar: La que surge de la puesta en acto del diseño curricular con las concreciones realizadas en función del proyecto institucional vigente en el establecimiento.

Extraescolar, aquella que se realiza dentro del amplio campo de las relaciones con la comunidad, actividades de participación en eventos locales, concursos, jornadas de recreación, competencias del distrito organizadas por terceros ajenos a la DGC y E por mencionar algunos.

Complementarias, aquella que se realiza con un grado de conexión directa con el proyecto institucional y que se relaciona por lo general con la participación de la comunidad educativa de la escuela, asociación cooperadora, asociación de ex alumnos, clubes de madres o similares cuya actividad tiene como eje y centro la escuela y el mejoramiento de la calidad de sus prestaciones. También debe estar claramente explicitado en el proyecto institucional y en el caso de no haber sido prevista deberá ser comunicada a nivel de supervisión que corresponda (rama, infraestructura o consejo escolar según se trate).

Cualesquiera sean el día, la hora y el lugar, queda claro que la responsabilidad civil del propietario del establecimiento educativo no se encuentra limitado por los conceptos de horario habitual del dictado de clases, día hábil o feriado o lugar de prestación del servicio. También este aspecto deberá quedar explicitado en el proyecto institucional ya que muchas actividades escolares, extraescolares o complementarias se realizan a contra turno, fuera del horario de clase y en espacios físicos que no son propiedad de la Dirección General de Cultura y Educación o que no coinciden con el establecimiento.

Pudiendo eximirse solamente probando el caso fortuito externo, se entiende por tal aquello que aún no previsto no puede evitarse, es decir situaciones externas a la vida y prácticas institucionales que pueden vincularse con fenómenos de la naturaleza (granizo, aludes, aluviones, inundaciones) o hechos de terceros que producen daños a los alumnos amparados por este artículo.

Los establecimientos educativos deberán contratar un seguro por la responsabilidad civil emergente de este artículo, deben entenderse que los propietarios deben 
contratar el seguro para afrontar las consecuencias dañosas que el desarrollo de la actividad escolar para producir. Tal obligación es de estricto y literal cumplimiento para los propietarios de establecimientos dependientes de la DIEGEP.

El resto de las escuelas bajo la responsabilidad de la Dirección General de Cultura y Educación no deben contratar ningún tipo de seguro ya que el índice de siniestros que se producen en la jurisdicción no ameritan que la misma contrate un seguro específico. Ello no significa la renuencia de esta DGC y E soporta pecuniariamente los reclamos de daños y perjuicios que pudieran producirse.

La provincia de Buenos Aires cómo tal asegura el pago de dichos reclamos. Las normas jurídicas aplicables a la cuestión de la responsabilidad civil estuvieron marcadas por la influencia de diferentes teorías que contestaban la pregunta básica ¿quién debe pagar la indemnización de los daños que sufren nuestros alumnos mientras se encuentran desarrollando actividades propias de la ejecución del diseño curricular vigente?

Muchos consideran que la educación física en la escuela es riesgosa, ¿quién nos garantiza que un alumno en el patio de la escuela no se fracture o se lesiones en las prácticas del profesor?

Ahora la lectura jurídica es otra ya que tiene en cuenta las situaciones que se producen dentro de la escuela, de allí se desprende que la responsabilidad de lo que ocurre es de quién toma la decisión de hacer funcionar las escuelas en la provincia de Buenos Aires. El estado es el que dicta la resolución ministerial. El propietario de las escuelas será entonces el responsable de lo que ocurra a los alumnos mientras cumplen actividades de educación física en la escuela. La Dirección General de Cultura y Educación como los propietarios de los privados son los dueños de las escuelas donde trabajamos.

Lo que ocurra en la escuela es responsabilidad del propietario y a este le corresponde asumir la obligación de pagar todas las consecuencias de los daños que sufran sus alumnos. Esta es la teoría, en las entrevistas a los profesores y en la práctica veremos si es así. Los profesores serán responsables solamente si dejaron de cumplir con las obligaciones que están a nuestro cargo y que precisamente, deben ser leídas y puestas en acción en nuestras prácticas. 
La responsabilidad civil en la escuela debe ser abordada con todos los integrantes docentes y no docentes. A todos les resulta indispensable adquirir conocimientos y conceptos referidos a la responsabilidad civil, como así también saber de la terminología jurídica básica para actuar como agentes multiplicadores a través de jornadas o foros de discusión y reflexión.

Se puede observar que desde el ámbito de la enseñanza los docentes en general tienen la "sensación" de no estar suficientemente protegidos respecto a las consecuencias que se derivan de la responsabilidad civil por los daños que se pudieran ocasionar en las clases del patio de educación física. Dentro o fuera de la escuela en la actividad escolar y extraescolar se pueden derivar y se derivan accidentes. Cuando hablamos de responsabilidad civil, estamos hablando de prevención y prevenir no es nada más ni nada menos que anticiparse al peligro, al accidente, a lo que puede provocar una lesión en el alumno.

¿En cuántas reuniones participamos relacionadas con estos temas?

¿Por qué tratamos el tema generalmente luego de que paso el hecho?

El no tratar el tema convenientemente se produce un desgaste sistemático entre la relación vincular directivos, docentes, escuela, comunidad, etc. Las dificultades deben ser abordadas dentro de la institución escolar. Si uno de nuestros alumnos sufre un daño practicando la actividad que se derive en un reclamo, debemos preguntarnos:

¿Dónde ocurrió?

¿Qué se reclama?

¿Contra quién se dirige la acción?

Las prácticas de educación física en la escuela no se limitan solamente al patio sino que orientan su accionar con sus prácticas en otras de diferente naturaleza, las deportivas que no necesariamente tienen lugar en el ámbito físico en que se desenvuelven normalmente, incluyen los campamentos, actividades al aire libre, recreación, viajes por torneos o encuentros con otras escuelas. Solo se eximirá de responder el titular del establecimiento, que demuestre que el hecho no pudo ser previsto o aún previsto, no pudo ser evitado. Dentro de este contexto el profesor de 
educación física podrá ser demandado por el accidente sufrido por el alumno a su cargo, o por los daños provocados por un alumno a su cargo contra otro, o por un alumno a su cargo contra un tercero.

Se debe tener en cuenta que el profesional de educación física si actuó con negligencia o culpa o dolo, puede ser demandado civilmente conforme al artículo 1.109 del Código Civil y hasta condenado igual que el titular del establecimiento. Aún en caso de responder el titular del establecimiento, éste puede ejercer la acción de regreso (artículo 1.123 del Código Civil) contra su dependiente, por haber obrado este último con culpa grave el total de la indemnización o el porcentaje que se le haya adjudicado al docente en caso de responsabilidad concurrente (cuando más de una persona deba responder).

El profesor puede ser sujeto pasivo de una acción penal en caso de imprudencia o negligencia grave, como por ejemplo lesiones graves o muerte del alumno. El docente puede responder por incumplimiento de su débito laboral ya sea por la vía administrativa (empleo público vía pre sumario o sumario, cuya sanción más grave es la exoneración del agente) o laboral (empleo privado, cuya sanción más severa es el despido).

Es importante destacar que con la nueva reforma del artículo 1.117 del Código Civil es personal directivo de las escuelas han sido justamente beneficiado dado que ya no pesa sobre estos la responsabilidad refleja que establecía la anterior redacción del artículo citado y que agravaba en forma injustificada la situación del director de la escuela.

Por lo tanto en la realidad y a partir de la reforma las demandas por daños y perjuicios por responsabilidad civil en principio y en líneas generales serán dirigidos contra el propietario del servicio educativo, debiendo esa contestar a través de sus asesores legales las acciones judiciales iniciadas en su contra.

Sin embargo y por vía de excepción el personal docente puede ver comprometida su responsabilidad civil cuándo en el cumplimiento de sus funciones inherentes al cargo que desempeña hubiera actuado con dolo o culpa y tal conducta hubiera provocado un hecho dañoso a un alumno o tercero. En tal hipótesis quién demande (padre del alumno, tutor, tercero, etc.) deberán demostrar tales extremos y podrán dirigir la acción 
de acuerdo a su elección contra el docente en forma directa y separada o demandar en forma conjunta tanto a la entidad propietaria como al docente responsable.

Por eso es importante que los docentes extremen sus cuidados y deber de diligencia en el cumplimiento de sus funciones inherentes al cargo que desempeñan con el objeto de brindar una vigilancia activa y permanente de los educandos que están a su cargo. De tal manera se garantiza en forma idónea el cumplimiento de la obligación accesoria de seguridad que comprende tanto la integridad física como psicológica del alumno y se disminuirá la posibilidad de una acción de indemnización contra el docente.

Realizar control periódicos de las instalaciones, de los bienes, muebles que pudieran generar riesgos a los alumnos en las clases por su mal estado de conservación. Se debe solicitar en forma urgente por escrito la reparación de las deficiencias técnicas ante los responsables.

Tomar las medidas de seguridad y control de los alumnos en el acceso al patio y al salir. Deberían estar cerradas con dispositivo de seguridad y bajo control de una persona designada por la autoridad.

No permanecer en el patio de la escuela los alumnos sin clases.

En los horarios de educación física de cada práctica, los profesores no abandonarán la clase por ningún motivo y no dejar a los alumnos solos en el patio.

No darles ordenes o encargues a los alumnos en horarios escolares o extraescolares.

No realizar actividades de educación física por motivos climáticos en lugares cerrados que no cumplen con las condiciones de seguridad adecuadas.

Las obligaciones de un establecimiento educativo no se reducen a prestar educación en horarios determinados y por diseños curriculares aprobados y establecidos, sino que abarcan también la obligación de seguridad, vigente en el plano contractual y extracontractual, que comprende el deber de asegurar la integridad del menor a través del cuidado y vigilancia durante la guarda y su devolución sano y salvo a sus progenitores. 
La ley delega en directores de colegio y maestros artesanos una parte de la autoridad suficiente, para mantener a los menores que se encuentran bajo su vigilancia en los límites de circunspección y del deber. La escuela es junto con la familia, la institución social que mayores repercusiones tiene para el niño, no solo interviene en la transmisión del saber culturalmente organizado, sino que influyen en todos los aspectos relativos a los procesos de socialización e individualización del niño.

La actividad escolar, el daño que puede ser físico o moral, debe producirse mientras el menor se encuentre "bajo control de la autoridad educativa". A tales efectos tal hipótesis comprende toda actividad estrictamente curricular, la que se extiende a todas las que se vinculen a ella por el hecho de encontrarse organizadas y controladas por la autoridad educativa (o a través de sus dependientes, directores, docentes en general, preceptores, etc.), no se limitan a las realizadas en el patio, se incluyen las deportivas, viajes de estudio o recreación.

Es importante tener en cuenta pautas que se sugieren a cumplimentar a los directivos y docentes de los establecimiento educativos en caso de accidentes ocurridos en los servicios educativos.

1 - Urgente comunicación al servicio de emergencia contratado previamente por el establecimiento educacional, o al servicio de salud público más cercano.

2 - Se informará el hecho acaecido a los padres y o tutores del alumno accidentado.

3 - Se efectuará denuncia policial o exposición civil sobre los hechos acaecidos en la dependencia policial que correspondiere.

4 - Se labrará un acta del hecho ocurrido en el libro de actas de la escuela, detallando fecha, horario, lugar, circunstancias (testigos, imputados, agresores, posible daño). La misma será firmada por el directivo y el docente a cargo del turno en que el hecho haya ocurrido.

5 - Se notificará a los padres mediante acta, informando además que se encuentra a su disposición la cobertura del seguro por accidente. 
6 - El directivo deberá efectuar la denuncia a fin de tramitar el seguro, cumpliendo con los requisitos.

7 - Con carácter urgente avisar a la jefatura de región que corresponda, también ante cualquier consulta docente, puede requerir asesoramiento al área legal de la rama.

8 - A fin de deslindar responsabilidades administrativas el Inspector se encuentra facultado para realizar una investigación simple o pre sumario.

9 - El directivo deberá solicitar a los padres la certificación del médico que asistió al alumno el cual deberá guardarse en el legajo correspondiente.

10 - En los accidentes cumplimentar las formalidades requeridas por el seguro correspondiente. Los procedimientos para la denuncia del siniestro son:

Para acogerse al amparo de responsabilidad legal que cubre la póliza, la dirección de cada establecimiento deberá comunicar los incidentes ocurridos en un plazo no mayor a 48 horas a la Dirección General de Administración. Se remite por fax o nota dentro de los plazos señalados la siguiente documentación:

- Planilla de responsabilidad civil, establecimientos educativos, denuncia del siniestro.

- Copia del acta labrada.

- Certificado de alumno regular con horarios de actividades.

- Copia de denuncia o exposición policial si la hubiere, en caso de gravedad o internación.

- Alta médico si la hubiere.

El control del estado (nacional, provincial o municipal) y un particular o varias personas jurídicas o física, quién tiene la mayoría absoluta en la dirección organizativa de la enseñanza dará las características a la educación que se imparta. 
La obligación de seguridad que hallamos en el contrato se debe tener en cuenta que los docentes tienen la obligación de entregar a los estudiantes sanos y salvos a la salida del patio del colegio. Que exista un contrato de por medio significa que el actor podrá demandar a la parte que no cumplió con lo reglado convencionalmente.

La necesidad de un marco es importante siempre que el docente sepa que hacer, de qué lado está la normativa, a qué hora se inicia la clase, a qué hora finaliza, que se hace con el tiempo que sobre y en consecuencia, está bien, está enmarcado. El marco autoriza, exige, reclama, la transgresión individualista puede traer algún problema. Cuando el marco se quiebra por algún motivo, cuando la trama se va deshilvanando, el individuo decae, y con él las excelsas alegrías de ser uno mismo.

\section{Resolución 426/06.}

Con la mencionada Resolución Número 426/06 y su ampliatoria Número 1454/07 de la Dirección General de Cultura y Educación se aprobó la normativa reglamentaria aplicada a la realización de experiencias directas, lecciones paseos y/o salidas educativas.

La Resolución 1457/02, fueron reglamentadas las actividades reglamentadas las actividades de "vida en contacto con la naturaleza" en los establecimientos de nivel inicial, primaria, polimodal, especial, centro educativo y centro de educación física.

\section{Resolución 498/10.}

El 15/02/2010, se propone un nuevo marco teórico y normativo que unifica criterios y facilita a docentes y autoridades la promoción y concreción de los proyectos pedagógicos.

Tomando como las actividades que son promovidas y organizadas por las instituciones educativas, planificadas, conducidas por el personal docente, que conllevan una efectiva y responsable práctica profesional de la función docente como también fortalecen la autonomía, la creatividad y el sentido crítico de los alumnos. 
Implicando que los alumnos que participan de las mismas se encuentran a cargo de la autoridad educativa, quién tiene obligaciones específicas de cuidado y vigilancia activa de los mismos, resulto pertinente el alcance de los conceptos de salida educativa como de salida de representación institucional, por la presente Resolución se crean, norman los procedimientos y mecanismos de su implementación.

El Director General de Cultura y Educación Resuelve derogar las resoluciones número $426 / 06,1454 / 07$ y 1457/02 y toda otra norma que se oponga a la presente y aprueba la normativa reglamentaria para la realización de "salida educativa" y "salida de representación institucional” con el Número Resolución N 498.

Los procesos de enseñanza y de aprendizaje comprenden situaciones del profesor de educación física que acontecen en el patio escolar con las prácticas dentro como fuera del establecimiento escolar y que constituyen experiencias de relevancia. La diversidad de prácticas corporales que se desarrollan fuera del patio según su característica se las denomina por la resolución:

\section{Salida educativa. Representación institucional.}

Los alumnos inmersos en los problemas de seguridad en los patios escolares, las pocas prioridades edilicias en cuanto a infraestructura deportiva o para juegos, edificios inadecuados, los docentes con bajos salarios, padres con poco interés en la conducta de sus hijos y otros factores negativos, la escuela como el espacio del patio se ha convertido en un ámbito que, si bien no puede calificarse de totalmente peligroso, requiere por lo menos, la máxima atención, pues pareciera que prácticamente todo debe replantearse en él como repesar un nuevo patio.

Desde la escuela, el poder distrital, regional y provincial deben hacer un esfuerzo, la administración debe dictar normas que garanticen la seguridad en los patios, la presencia de los padres ocupándose de la educación de sus hijos, el esfuerzo de los profesores en el patio trabajando por una nueva educación física y la prudencia de los jueces dictando sentencias con indemnizaciones justas, cuando se hubieran producido hechos dañosos. 
Debe estar también el seguro cumpliendo con su función social de repartir los riesgos, para que las eventuales víctimas, que en el caso que se produjeran, son además, generalmente, de corta edad, para que reciban el resarcimiento correspondiente. Los establecimientos educativos están vinculados entre sí por una interdependencia funcional y organizados por sus propietarios con el fin de proveer servicio educativo. No están comprendidos, la educación impartida por un docente en forma individual aunque fuera en su domicilio, mucho menos si lo fuere en el domicilio del alumno.

Tampoco se puede sostener la existencia de un establecimiento en los casos de educación a distancia. Si existe participación o posibilidad de vigilancia por parte del establecimiento, puede verse este alcanzado por las responsabilidades. No lo cubre está póliza y la dirección debe deslindar toda responsabilidad.

El que no ha podido preverse, o que previsto no ha podido evitarse, interrumpe el nexo causal iniciado a partir del hecho $u$ omisión del presunto responsable, pues es una causa extraña e independiente a su voluntad, y produce daño.

Algunos sostienen que no solo exime el caso fortuito sino también la culpa de la víctima y del tercero. Otra postura entiende que libera de responsabilidad la culpa de la víctima o la del tercero, pero siempre que estas causas ajenas reúnan los caracteres del caso fortuito.

\section{Culpa de la víctima.}

Alumno mayor de 10 años, con serias limitaciones. alumno menor de 10 años, no exime.

\section{Culpa de un tercero.}

Siempre que no se deba responder por él, y que revista la categoría de "hecho fortuito" o "fuerza mayor". 


\section{Dolo.}

Una situación que merece plantearse es que sucede cuando el daño se ha producido como consecuencia del dolo (intencional) o la culpa (negligencia, imprudencia) de un docente determinado. No cabe duda de que, en caso, el propietario del centro educativo que ha pagado la indemnización a la víctima del daño o a su asegurado tendrá contra el docente una acción de recurso o de regreso, mediante la cual podrá intentar recuperar lo que hubiera abonado al damnificado.

\section{Riesgos Excluidos.}

Es importante tener en cuenta los riesgos excluidos en el establecimiento como en el patio donde el profesor de educación física trabaja con los cuerpos de los alumnos.

- Hechos privados del personal del establecimiento, considerando como tales los que no se vinculen con su actividad profesional o laboral.

- Daños que se produjesen por el uso de armas, excluyendo los derivados de tal uso por parte del personal de seguridad, al servicio del asegurado, autorizado para portar o guardar tales armas.

- Transporte de bienes y personas, aún cuando se trate de alumnos del establecimiento educativo.

- Responsabilidad civil patronal y/o accidentes de trabajo.

- Acoso y/o hostigamiento y/o molestia sexual, discriminación.

- Pagos graciables y transacciones extrajudiciales sin la intervención de la compañía de seguros. 
- Daños a bienes de terceros bajo cuidado, custodia y/o control del asegurado.

- Daños financieros puros.

- Daños ocasionados por caso fortuito, fuerza mayor o culpa grave e inexcusable de la víctima.

- Enfermedades profesionales.

- Guerra y/o guerra civil.

- Multas, penalidades, daños punitivos.

- Responsabilidad civil mala praxis médica, excepto cuando se trate de primeros auxilios.

- Responsabilidad civil cruzada.

- Responsabilidad civil profesional, errores u omisiones de cualquier clase.

- Siniestros originados por no reconocimiento electrónicos de fechas.

- Riesgos aéreos (paracaídas, parapentes, vuelos, globos, ala-delta, etc.)

- Alpinismo.

- Riesgos acuáticos de naturaleza peligrosa; rafting, navegación oceánica, buceo, etc.

- Deportes bajo tierra.

- Esquí excepto actividades básicas y normales, esquí sin supervisión de personal escolar o guías/tutores calificados. 
- Uso manipuleo y/o depósito de venenos para pesticidas en general, adhesivos de contacto, otros.

- Secuestro, toma de rehén, extravío y/o desaparición de personas.

- Cancelación de eventos.

- Uso de pirotecnia.

- Transporte aéreo, marítimo y/o fluvial de alumnos.

- Guarda y/o depósito de vehículos.

- Demoliciones, excavaciones, construcciones de edificios, instalaciones y montaje, con motivo de la construcción, refacción de edificios.

- Dolo por parte de los directores, profesores, y/o dueños de la institución.

- Calumnias e injurias, difamación y/o daño moral exclusivamente.

- Hechos propios, hechos privados del personal del establecimiento, considerando como tales los que no se vinculen con su actividad profesional o laboral.

- Daños intencionales y deshonestos de los alumnos, causados a terceros.

Si nos preguntamos en el patio ¿cuál es el ámbito espacial de la responsabilidad?, el propietario del establecimiento responde cuando un alumno sufre un daño hallándose en el patio de la clase de educación física de la escuela. También la responsabilidad se extiende a las salidas programadas por la escuela. Si el hecho dañoso se origina en el patio del establecimiento, pero produce efectos fuera de él (por ejemplo, lesión sufrida por un peatón, como consecuencia de una pedrada arrojada desde la escuela también responde el propietario. 
En cambio, si el alumno, al salir del colegio, concluido el horario escolar, sufre un accidente de tránsito se considera que no podría imputarse responsabilidad al propietario del establecimiento, en razón de que no puede extenderse la guarda asumida por éste hasta ese límite. Se consideran terceros y en consecuencia estarán excluidos de la cobertura, las personas en dependencia laboral con el asegurado y los contratistas y / o subcontratistas y sus dependientes. En la denuncia de los accidentes es importante el debido diligenciamiento del formulario de denuncia. El establecimiento no siempre debe responder de todo daño a los estudiantes, pues en el hecho debe tenerse en cuenta la capacidad de los niños para herirse sin culpa de aquellos que los vigilan.

Toda vez que un alumno sufre un daño en un patio de la escuela durante el horario escolar, corresponde al establecimiento demostrar su falta de culpa o la observación de todos los cuidados que corresponde a su deber de vigilancia, mientras que el alumno (padre) le basta con acreditar que el perjuicio padecido por el estudiante se produjo dentro de la escuela. En muchos casos aún con todos los cuidados no ha podido evitarse por ser un hecho imprevisto e inevitable.

Los procesos legales en caso de accidentes producidos dentro del establecimiento educativo deben proporcionar una atención inmediata al alumno accidentado en la clase de educación física, llamar a los responsables de los alumnos (padre, madre o tutor). Contactar al médico, donde será atendido el alumno, mientras llega el servicio solicitado, atendiendo el docente los primeros auxilios, según su conocimiento o de las personas que lo asistan.

Nunca suministrar medicamentos algunos, ni siquiera una aspirina. Labrar acta describiendo el hecho, los responsables de los alumnos tomara conocimiento y firmará el acta (profesor o docente a cargo en el momento del accidente). Si se requiere internación o traslado a un centro de salud, un docente acompañará, con un responsable, al alumno, debiéndose efectuar la denuncia policial en un plazo máximo de 48 horas.

No desestimar los accidentes y primar criterio objetivo sobre la intención subjetiva. Los accidentes no se pueden considerar como leves, dado que los profesores o docentes aunque tengan conocimientos de primeros auxilios no son médicos. Todos los 
accidentes se tienen que reportar, sean leves o no, a la Dirección de la escuela a fin de proceder a la denuncia del hecho.

Prevenir eventos dañosos y a la vez cubrir la responsabilidad de los directivos y docentes del establecimiento, realizar un relevamiento del estado actual de las instalaciones de la escuela como aulas, patios, gimnasios, salón de usos múltiples, escaleras, columnas, etc. Si hay construcciones detallarlas, como también manifestar sus peligros. Estos relevamientos se hacen una vez por año y actualizarlo en cada situación de peligro concreta que se presente.

Indicar los posibles riesgos que puedan ocurrir considerando su buen criterio por el docente, sobre todos durante los recreos escolares o en las horas de nivel medio. Elevar informes a dirección en caso de ser elaborados por el docente y en todos los casos a la supervisión, quién deberá hacer llegar el informe a la dirección de infraestructura y mantenimiento, dependiendo del consejo escolar del distrito. Agregar los informes de las planificaciones anuales correspondientes.

\section{3. "Profesor y su concreción en el patio"}

La función de los profesores de educación física parece ajena a la órbita jurídica, pero en la sola aparición del conflicto se hace visible. Los profesores que trabajan en los patios de las escuelas se desempeñan la mayor parte de las veces sin tener en consideración lo expuesto y en general por desconocimiento de los preceptos que nos regulan en el accionar.

Funda su accionar olvidando el basamento jurídico subyacente y actuando a veces en forma equivocada por desconocimiento, no justificado, de sus derechos y obligaciones. A veces se guía por usos y costumbres por lo que intento desarrollar el conocimiento de la normativa legal vigente en la actualidad.

Si hablamos de los profesores en los patios seguros obedientes a la normativa, sería circunscribirnos, al conocimiento de la misma y su ubicación como problemática de reflexión, entendemos que la sociedad jurídicamente organizada requiere hoy en la actualidad de un entramado legal que facilite la convivencia y evite conflictos como también que prevea sanciones cuando las conductas de los individuos así lo exijan. 
El profesor de educación física se mueve dentro de un marco normativo y a su vez ve muchas veces la necesidad de modificarlo o crearlo en su caso negándose o dando permisos, por desconocimiento o inseguridad a realizar el intento, emprendiendo un camino para ello.

La clasificación de las normas nos enseñan diferencias sustanciales entre las mismas que a su vez nos mostrará su origen, fundamentación, ideología que la sustenta, etc., elementos necesarios para efectuar críticas y propuestas. Los aspectos legales se los considera como algo vivo en las prácticas profesionales que trabajan con el cuerpo externo, cuerpo vivo en un contexto histórico - social que es susceptible de ser modificado por impulso de la dinámica social siendo el mismo profesional capaz de comprender dichos cambios o impulsor de los mismos a través de las instituciones educativas correspondientes.

Es el deber de resarcir los daños causados y los perjuicios provocados por sí o por un tercero, por el que se debe responder. Contractual, si originada en el incumplimiento de un contrato válido y extracontractual, cuando deriva del hecho de haberse producido un daño que es ajeno a toda vinculación convencional por culpa o dolo.

Por el hecho propio, cuando es ocasionada por hechos en omisiones propias y por el hecho ajeno, cuando es ocasionado en hechos en omisiones ajenas (padres / hijos, tutores / menores y directores del establecimiento). La responsabilidad subjetiva, cuando surge por la acción u omisión de hechos propios o ajenos, por culpa o negligencia.

La responsabilidad objetiva, también llamada sin culpa, responde a teorías del riesgo creado, según los cuales el patrón responde por los daños físicos de sus labores, o como consecuencia de ellos, con independencia de que haya mediado culpa o negligencia y aun cuando se hayan producido por imprudencia o la culpa no grave de la propia víctima.

Satisfacer a la víctima a través de una prestación patrimonial, que se impone a favor de este. La sola circunstancia de que el hombre viva en sociedad está sometida a un deber genérico de no dañar. La violación al deber genera la responsabilidad como sanción.

\section{4. "Presupuesto de la Responsabilidad".}


1 - Incumplimiento objetivo, que consiste en la infracción al deber. Art. 1066: Ningún acto voluntario tendrá el carácter de ilícito sino fuese expresamente prohibido por las leyes ordinarias.

2 - Factor de atribución de responsabilidad, que puede ser subjetivo u objetivo, que es la razón para asignar el deber de reparar.

A) Subjetivo.

B) Objetivo.

A) La noción de culpa constituye el sustento subjetivo de la responsabilidad. Los actos voluntarios deben tener como componentes:

- Discernimiento: obstan al discernimiento la minoridad, el sujeto está dotado para los actos ilícitos a los 10 años y para los ilícitos a los 14 años.

- Intención: El menor esencial que recaiga sobre el hecho principal, sin culpa del autor, obstan a la intención.

- Libertad: La fuerza irresistible o el temor fundado de sufrir un mal grave, configuran el vicio de violencia, que obstan a la libertad.

\section{5. “Culpa”}

"La culpa del deudor en el cumplimiento de la obligación consiste en la omisión de aquellas diligencias que exigiere la naturaleza de la obligación y que correspondiesen a las circunstancias e las personas del tiempo y lugar (512 C.C.)

- La culpa proviene de un acto voluntario realizado con intención, discernimiento y libertad.

- La culpa puede presentarse en sus versiones. 
a) Negligencia: Cuando el sujeto omite cierta actividad que habría evitado el resultado dañoso.

b) Imprudencia: Cuando el sujeto obra precipitadamente o sin prever las consecuencias en que podría desembocar.

c) Elementos:

B) Existe una expansión de la atribución objetiva del deber de reparar el daño, se trata de la teoría del riesgo, que pone el resarcimiento a cargo de quién emplea una cosa o desarrolla una actividad apta para causar un daño.

Se desplaza la culpa del autor.

- Daño: Consiste en la lesión a un derecho subjetivo de la víctima.

- Relación de Causalidad: Que es la causa suficiente entre el hecho y el daño.

\section{6.“responsabilidad por accidentes en la Escuela por Accidentes Deportivos"}

En la escuela organizada por la misma o por el profesor en relación con la configuración de movimiento "Deporte" se debe prever posibles responsabilidades por accidentes deportivos.

Régimen: El régimen aplicable a esta responsabilidad especial, se distingue entre los daños ocasionados a los participantes de la competencia deportiva, y los daños que sufran los extraños a ella (espectadores o simples terceros).

Daños a participantes, distintos casos dentro de la problemática que generan los daños sufridos por los participantes de una prueba deportiva, debemos -a su vezdistinguir los siguientes casos:

1 - Daños causados por un participante a otro.

2 - Daños atribuibles a la entidad deportiva. 
Daños a extraños: Cuando el daño lo sufre un tercero ajeno a la competencia deportiva, está fuera de discusión que la responsabilidad, en caso de nacer, tiene fuente extracontractual.

\section{7. “Responsabilidad derivada de los Espectáculos Públicos”}

Naturaleza de la responsabilidad, la que emerge de la organización de espectáculos públicos es nítidamente contractual. La jurisprudencia reconoció este carácter al afirmar que la responsabilidad del empresario de espectáculos públicos surge del contrato innominado que vincula al empresario con el espectador y entre cuyas cláusulas implícitas, por razón de la misma naturaleza, debe considerarse comprendida la que atañe a la seguridad personal de los concurrentes, por lo que está obligado a velar el empresario.

\section{8. "Responsabilidades Profesional"}

El sustantivo profesional engloba un doble concepto. La doctrina tradicional ha tomado en cuenta este sentido estricto, que corresponde al denominado profesional liberal. Se debe tener en cuenta en las organizaciones en caso de delegaciones, representaciones si actúan como dependientes de la Provincia de Buenos Aires (Dirección General de Cultura y Educación), por las imputaciones de faltas "in eligiendo "in vigilando" sobre los posibles alcances de las indemnizaciones pretendidas.

El ser es alguien que posee inteligencia y voluntad, por lo que puede actuar ejerciendo sus facultades. Es un ser social el que vive agrupado a sus semejantes, vive en sociedades y por lo tanto, su libertad debe ser ejercida con el límite del respeto que debe a la libertad. En la sociedad se establecen normas que serán las garantías para que cada habitante se le asegure el ejercicio de las facultades. Los derechos de uno terminan donde comienzan los derechos de los otros.

La norma es una pauta de conducta o manifestación social, son la descripción de una forma de comportamiento ante una situación. Todas las normas tienen en su estructura una hipótesis y una consecuencia. Están las normas morales y las normas jurídicas. Las primeras establecen reglas de conducta individual, que no son de 
aplicación obligatoria, las segundas son reglas establecidas por las autoridades públicas para regir las relaciones de los hombres entre sí y de estos con el estado.

Las normas jurídicas forman parte del ordenamiento jurídico de un estado determinado, son obligatorias, fijando los principios y modos de resolver los conflictos que se originan en el ámbito de estas relaciones. Todos los profesores de educación física en el desarrollo de las prácticas, tienen responsabilidad frente a sus alumnos a su cargo.

Al ver los patios de los profesionales en la actualidad donde los profesores cumplen con la tarea docente es importante tener en cuenta que no actúen con negligencia: (falta de cuidados en el patio, abandonen a sus alumnos en clase, descuiden al mismo, olviden u omitan, como la imprevisión.). Asimismo la imprudencia (falta de prudencia, actitud temeraria que pone en riesgo o peligro a los alumnos a su cargo o a terceros.). La impericia es también la negligencia o la imprudencia llamada también la mala praxis.

En la actividad los profesores son públicos y toman las medidas preventivas dentro y fuera del patio de la escuela, en cualquier práctica o situación de las personas, la prevención es lo que evita las posibles consecuencias dañosas que se producen por la falta de cuidado. Es importante contar con los medios adecuados para realizar la misma, porque la consecuencia de no tenerlos es una de las causales de siniestros más importantes.

Es recomendable redactar en cada escuela y con la participación de directivos como de los docentes, los reglamentos que identifiquen los riesgos que puedan prevenirse con medidas concretas y colaboración de los padres. Es importante que los reglamentos sean firmados por los padres, integrantes de la cooperadora, directivos, docentes y alumnos.

Denunciar los profesores en las escuelas donde trabajemos, los pisos deslizantes, escaleras sin resguardos, paredes con aristas cortantes, puertas y ventanas con paños de vidrios grandes, materiales inadecuados, deterioro de mobiliario, falta de aprobación de artefactos o elementos por autoridad competente, falta de disyuntores o matafuegos adecuados, etc. 
Agregar la revisión periódica de sistemas eléctricos e instalaciones de gas, los disyuntores, análisis de agua que se utiliza en la escuela, inspecciones de bromatología en escuelas que brindan servicio de comedor, etc. Si las clases de educación física las dictamos en el polideportivo solicitar que reparen, mantengan y/o construyan cercos perimetrales y enrejados. Mantener o solicitar instalación de columnas de alumbrado exterior, denunciar la rotura y/o falta de tapas del sistema cloacal, revisar los medidores y tapas de cajas del sistema de gas.

Denunciar y exigir el adecuado mantenimiento de juegos infantiles y que estén construidos sobre pisos de arena, ajustándose a las dimensiones de la reglamentación vigente. Procurar la limpieza periódica de patios y espacios externos (eliminar vidrios, latas, alambres, etc.). Solicitar la instalación de rampas para discapacitados, como también pasamanos en las escaleras de acceso a distintos niveles. Al profesor de educación física se le hace necesario conocer principios, fundamentos y conceptos del derecho laboral a quienes tiene la responsabilidad de dirigir las instituciones educativas.

Tanto el empleador como el trabajador deben cumplir lealmente sus obligaciones, la tarea del profesor implica connotaciones que pocas profesiones abarcan. Por un lado el continuo avance de las técnicas cómo de las teorías, por otro el cambio constante de la sociedad y por ende de los destinatarios de la educación, un alto nivel de exigencia y compromiso por el significado de la tarea, valorada socialmente.

Si hablamos de prevención del daño se debe aclarar que no es tarea exclusiva de la responsabilidad civil. Son eficaces las regulaciones administrativas (por ejemplo las normas contra incendios, obligación de utilizar cinturones de seguridad, las normas de las construcciones, etc.) y también las sanciones penales. Lo que no quiere decir que la responsabilidad civil, modernamente no pueda ser vista como un instrumento más de prevención de los daños.

Podemos hablar de dos aspectos muy importantes a tener en cuenta: el primer aspecto preventivo podemos llamarlo económico, pero también puede ser enfocada desde el ángulo jurídico, de la responsabilidad civil, porque el derecho penal y el derecho administrativo son también instrumentos útiles de prevención. Para que exista responsabilidad civil debe haber daño. 
También tiene la responsabilidad civil una función preventiva, es decir de actuación de anticiparnos o adelantarnos antes que ocurra el daño, de evitación de que el perjuicio suceda.

¿Qué es entonces lo que distingue la responsabilidad civil de otras responsabilidades impuestas por el derecho se pregunta a menudo los profesores de educación física?

En primer lugar en que la responsabilidad civil debe existir daño, lo que puede no acontecer en el derecho penal o en el derecho tributario con las infracciones formales. En segundo lugar la responsabilidad civil no es excluyente de otras responsabilidades y bien puede afirmarse que es complementaria. Por ejemplo si el delito penal ha causado un daño este debe ser indemnizado, lo mismo que el hecho por el cual se priva de la patria potestad al padre, también puede generar obligación de indemnizar al hijo (malos tratos, por ejemplo).

Podemos decir que la responsabilidad civil no es subsidiaria, es decir no se impone luego de las otras sanciones o cuando éstas no se han impuesto, por lo que puede coexistir con la responsabilidad penal, ética, administrativa, sin dar lugar a planteos. Incluso la responsabilidad civil puede ser previa.

El derecho es una herramienta indispensable para que la convivencia humana sea posible, lo que se logra instaurando un sistema de controles variados, que se expresan mediante normas, mandatos, prohibiciones, costumbres, etc., los que en caso de no ser respetados generan en el sujeto el deber de responder.

En el estado actual de la evolución de la historia del hombre la responsabilidad civil y la penal se han separado en casi todos los sistemas jurídicos del mundo. No siempre el ilícito penal fue distinto del civil y las consecuencias de los hechos. La responsabilidad civil atraviesa las prácticas de los profesores de educación física. Los análisis de los discursos como los problemas en los patios nos permiten explorar aún más en esta época los conceptos de norma y ley en particular. Lo establecido por la ley entre lo permitido o lo prohibido, como también la norma expresa una cierta gradualidad entre un más y un menos. 


\section{Capitulo III}

\section{1. "Encuadres Legales"}

El capítulo anterior tratamos los temas de responsabilidad civil en la escuela, en las prácticas profesionales, las obligaciones del propietario y la concreción en el patio con sus normativas y vamos a seguir con los encuadres legales entendiendo que en la escuela las normativas están en todo momento.

Sin lugar a dudas, el tema responsabilidad civil, antes y después de las reformas ha provocado la inquietud e interés en docentes, no docentes y jurisconsultos que han expuesto, desde sus puntos de vista, diversas opiniones sobre la cuestión. Específicamente, la responsabilidad civil de los Directivos y los institutos de enseñanza ha sido escasamente tratada, sin que por esto le quitemos importancia a los pocos trabajos que se hallan escritos.

El sistema legal está sometido a cambios, y esto ocurre con bastante frecuencia a causa del constante progreso que vivimos. El derecho es social, abarca la realidad desde todos los planos que le corresponde. Lo normativo no es extraño a lo social, ambos comparten un espacio en común. No hay sociedades sin normas, sean jurídicas, morales o religiosas. Son un auxilio para la paz, para la convivencia en distintos contextos.

La concurrencia de alumnos en los patios, de los establecimientos educativos, que muchas veces sin prever las consecuencias de sus propias actividades perjudica a otros alumnos o a terceros. Los daños deben ser reparados, resarciendo los perjuicios ocasionados a terceros o a las cosas. Para que pueda ser reparado, debe ser cierto, ya sea presente o futuro, y además subsistente. 


\section{Constitución Nacional}

Artículo 31: Esta constitución, las leyes de la nación que en su consecuencia se dicten por el congreso y lo tratados con las potencias extranjeras son la ley suprema de la nación; y las autoridades de cada provincia están obligadas a conformarse a ellas, no obstante cualquiera disposición en contrario que contengan las leyes y constituciones provinciales, salvo para la provincia de Buenos Aires, los tratados ratificados después del Pacto del 11 de Noviembre de 1.859.

Artículo 5: Cada provincia dictará para si una constitución bajo el sistema representativo republicano, de acuerdo con los principios, declaraciones y garantías de la constitución nacional, y que asegure su administración de justicia, su régimen municipal y la educación primaria. Bajo estas condiciones el gobierno federal, garante a cada provincia el goce y ejercicio de sus instituciones.

Artículo 123: Cada provincial dicta su propia constitución, conforme a lo dispuesto por el artículo 5, asegurando la autonomía municipal y reglando su alcance y contenido en el orden institucional, político, administrativo, económico y financiero.

\section{Constitución Provincial}

Artículo 198: La constitución provincial en este artículo consagra como derechos humanos fundamentales, la cultura y educación. Toda persona tiene derecho a la educación y a tomar parte libremente en la vida cultural de la comunidad. Considera a la Familia como el agente educador y socializador primario, siendo la educación responsabilidad indelegable de la provincia, quién coordinará institucionalmente el sistema educativo y proveerá los servicios correspondientes, asegurando el libre acceso, permanencia y egreso a la educación en igualdad de oportunidades y posibilidades.

Artículo 200: La prestación del servicio educativo se realizará a través del sistema educativo provincial. La legislación de base de dicho sistema educativo se ajustará a los principios: 
- Gratuidad.

- Obligatoriedad.

- Equidad.

- Control Estatal.

Artículo 201: Prevé que la Dirección General de Cultura y Educación tendrá:

- Rango ministerial.

- Autarquía.

- Es un ente autárquico porque tiene personería jurídica propia distinta a la del Poder Ejecutivo Provincial.

- Administra su propio presupuesto.

- La ley da el marco en el cual se organiza la educación provincial.

La Dirección General de Cultura y educación debe ser considerada un órgano extra poder, diferenciándose de los demás poderes del estado (ejecutivo, legislativo y judicial) por su especialidad.

Artículo 202: Contempla el consejo general de cultura y educación con funciones de asesoramiento.

Artículo 203: Se refiere a los consejos escolares, considerándolos como órganos desconcentrados de la administración.

En la breve reseña de los marcos legales, se denomina "Responsabilidad Civil" la que surge como consecuencia de los hechos dañosos provocados a terceros por dependientes de este organismo o quienes estén bajo su guarda.

Encontrándonos en el marco normativo, en el patio escolar, perteneciente a la escuela, las prácticas de educación física requieren de la reflexión epistemológica que nos 
permita ir de la reflexión sobre el objeto de estudio a la reflexión y crítica de las teorías que hace construido el campo y el objeto.

Un cuerpo interno encuadrado en el contexto salud, referido al funcionamiento orgánico, enfermedad, abuso, deterioro y un cuerpo externo que tiene que ver con la apariencia, movimiento, control del cuerpo en el espacio social.

La educación física fue atravesada por paradigmas impropios, resultantes de la expansión sobre su campo de modelos establecidos a partir de los hallazgos empíricos de otras ciencias. Lo fundamental es que los conceptos y normativas de la educación física revelan que con la intrusión de su territorio por los supuestos epistemológicos de otros campos, se yuxtaponen y fragmentan como también confunden las prácticas.

La reflexión epistemológica sobre la responsabilidad civil nos permite incorporar la dimensión de la construcción del conocimiento en el debate actual acerca de una disciplina que ha asumido y asume, en general, la posibilidad de conocimiento objetivo, a la vez que se ha asumido y todavía se asume como eminentemente perceptivo.

La realidad de la responsabilidad civil parece ser compleja y difícil. El cuerpo no está solo, no siempre el cuerpo es uno y el mismo. El lenguaje ligado a la práctica en términos de la acción. Si el saber es subjetivo, vinculado a lo personal, circula y tiene una elaboración social y cultural ligado al devenir funciona o no aquel que lógicamente funciona en una realidad determinada con un sujeto determinado.

El cuerpo, sujeto y conocimiento en los paradigmas no se diferencian. El saber está en la cultura, lo apropiamos o no y es científico. Los significados tienen que ser compartidos y el conocimiento es una obra de creación. El cuerpo y sujeto están siempre en las acciones. Por tal motivo pensamos, ¿dónde estamos parados los profesores de educación física con el tema responsabilidad civil?

Si tenemos que tratar con conocimientos públicos, los contenidos y métodos se hallan inseparablemente interrelacionados, donde el profesor en el patio escolar tiene la misión de poner a disposición del alumno una selección de capital intelectual, emocional, técnico con que cuenta la sociedad. El capital es designado como tradición 
pública, estos son enseñados en las escuelas, son hechos sociales, y constituyen temas de estudio para el científico social.

El problema de la responsabilidad civil en las prácticas corporales comienza cuando uno no se da cuenta que hay otros que eligen por nosotros, quizás nos permitamos no copiar y repetir más. Necesariamente en los encuadres legales del patio escolar debería incorporar algunas precisiones terminológicas.

La gestión, como conjunto de actuaciones integradas para el logro de un objetivo a cierto plazo, es una toma de decisiones a diario para el profesional. Como es un eslabón intermedio entre lo que planificamos y los objetivos que pretendemos alcanzar. Por lo general en las instituciones educativas, comprenden algunas acciones que no debemos pasar por alto:

- Administrativas.

- Legales.

- Gerenciales.

- De política.

- Económicas.

- De planificación.

- De programación.

- De control.

- De orientación.

La evaluación como proceso de identificación, obtiene y proporciona información útil y descriptiva.

Todo Plan, como decisión de carácter general expresan los lineamientos políticos fundamentales, las prioridades que se derivan de las formulaciones, la asignación de 
los recursos, las estrategias de acción y el conjunto de medios e instrumentos que se van a utilizar para alcanzar las metas y los objetivos propuestos.

Tiene por finalidad trazar el curso deseable y probable del desarrollo nacional o del desarrollo de un sector (económico, social o cultural). Decisiones técnico - políticas en las que se enmarcan programas y proyectos.

El Programa, como conjunto organizado, coherente e integrado de actividades, servicios o procesos expresados en un conjunto de proyectos relacionados 0 coordinados entre sí y que son de similar naturaleza. Un plan está constituido por un conjunto de programas, un programa opera en un plan mediante.

Los Proyectos como conjunto de actividades concretas, interrelacionadas y coordinadas entre sí, que se realizan con el fin de producir determinados bienes y servicios capaces de satisfacer necesidades o resolver problemas.

La Responsabilidad Civil importa un deber que, como respuesta adecuada, soporta quien ha causado un daño, perjuicio o detrimento. Quién es responsable tiene que indemnizar a la víctima. Víctima y victimario, daño y dañador: a quién padece el perjuicio y a quién es agente del mismo. Definir a la responsabilidad civil requiere atenerse a lo que es la regla, dejando para más adelante las hipótesis de excepción.

\section{Estatuto del Docente.}

El Estatuto del Docente ${ }^{6}$, que por el Senado y cámara de diputados de la provincia de Buenos Aires sancionan con fuerza de ley en sus artículos:

Artículo $1^{\circ}$. Aprueba el Estatuto del Docente del Persona que se desempeña en todos los niveles, modalidades y especialidades de la Enseñanza y Organismos de Apoyo, cuyo texto como anexo único forma parte de la presente ley.

Artículo $2^{\circ}$. Deroga el Decreto Ley 19.885 / 57.

Artículo $3^{\circ}$. Comuníquese al Poder Ejecutivo.

\footnotetext{
${ }^{6}$ Ley $\mathrm{N}^{\circ}$ 10.579. Año 2010, $16{ }^{\circ}$ Edición. Páginas 5, 7,8, 9. Estatuto del Docente Provincial, Buenos
} Aires. Senado y Camara de Diputados de la Provincia de Buenos Aires sancionan con fuerza de ley. 
Dada en la sala de sesiones de la honorable legislatura de la provincia de Buenos Aires, en la ciudad de La Plata, a los veintidós días del mes de octubre de mil novecientos ochenta y siete.

En las disposiciones generales, el presente estatuto determina los deberes y derechos del personal docente que ejerce funciones en los establecimientos de enseñanza estatal, dependientes de la Dirección General de Escuelas y Cultura de la Provincia de Buenos Aires o en sus organismos, y cuyos cargos se encuentran comprendidos en el escalafón general que fija el estatuto.

Revistan en situación docente a los efectos del estatuto quienes habilitados por títulos competentes: imparten y guían la educación de los alumnos, dirigen, supervisan u orientan la enseñanza en cualquiera de sus niveles, modalidades y especialidades, colaboran directamente en las anteriores funciones y realizan tareas de investigación y especialización técnico - docente.

El personal docente contrae las obligaciones y adquiere los derechos establecidos en el estatuto, desde el momento en que se hace cargo de la función para la que es designado en carácter de titular, titular interino, provisional o suplente, con las limitaciones que en cada caso se determinen.

La situación de revista del personal docente será: pasiva, cuando se encuentre en uso de licencia por causas particulares o en disponibilidad sin goce de sueldo o se encuentro suspendido por sanción recaída en sumario administrativo o proceso judicial y activa, cuando no se encuentre en los supuestos precedentemente mencionados.

La situación docente, a los efectos del estatuto, se pierde cuando el docente cese por cualquiera de las causales establecidas en el mismo, o por acogimiento a los beneficios jubilatorios.

Las obligaciones y derechos del profesor de educación física que trabaja en las escuelas son:

- Desempeñar digna, eficaz y responsablemente las funciones inherentes al cargo. 
- Observar dentro y fuera del servicio donde se desempeñe una conducta que no afecte la función y la ética docente.

- Formar a los alumnos en las normas éticas y sociales con absoluta prescindencia partidaria y religiosa, en el amor y respeto a la patria y en el conocimiento y respeto de la constitución nacional y provincial.

- Aplicar su cultura y formación pedagógica, procurando el perfeccionamiento.

- Conocer, respetar y cumplir el presente estatuto.

- Cumplir las normas que se dicten para la mejor organización y gobierno de la enseñanza.

- Respetar las normas sobre jurisdicción y vía jerárquica en lo docente, administrativo y disciplinario.

- Declarar bajo juramento los cargos y/o actividades oficiales o privadas computables para la jubilación que desempeñe o haya desempeñado.

- Declarar y mantener actualizado su domicilio ante el establecimiento o repartición donde preste servicios, el que subsistirá a todos los efectos legales, mientras no denuncie otro nuevo.

- Declarar en los sumarios administrativos ordenados por autoridad competente siempre que no tuviera impedimento legal para hacerlo.

- Mantener el secreto, aún después de haber cesado en el cargo, de los asuntos del servicio que por su naturaleza o en virtud de disposiciones especiales sea necesario.

Se entiende como función docente aquella que debe desempeñar el agente en su cargo, conforme lo que establece el Estatuto del Docente, su reglamentación y demás normas vigentes. Entiendo por ética docente el respecto de los derechos fundamentales consagrados en la constitución nacional y provincial y las leyes que reglamentan su ejercicio. 
Es importante la formulación de la declaración jurada por escrito en forma simultánea con el acta de toma de posesión del cargo respectivo y en cuanta oportunidad se le requiera. La Dirección General de Escuelas y Cultura clasificará a los Establecimientos de Enseñanza:

Son derechos del personal docente titular: ${ }^{7}$

- La estabilidad en el cargo, categoría, jerarquía y ubicación o destino.

- La percepción de una remuneración justa, acorde con la responsabilidad y la jerarquía de las tareas que realiza.

- El ascenso, la permuta y el traslado de acuerdo con las condiciones establecidas en el presente estatuto.

- El progresivo acrecentamiento de horas - cátedra, hasta el máximo compatible.

- El cambio de funciones en caso de disminución o pérdida de aptitudes psico - físicas, cuando no se alcancen a cumplir los requisitos establecidos para la jubilación por incapacidad.

- El conocimiento de las nóminas de aspirantes de sus antecedentes, y del listado por orden de mérito, en casos de concursos, contrataciones, ascensos, acrecentamiento de horas - cátedra y traslados.

- En derecho a vista en toda actuación en la que sea parte interesada, con las limitaciones que establece el presente estatuto y su reglamentación y leyes aplicables.

- La defensa de sus derechos mediante las actividades y recursos que este estatuto y demás normas legales establezcan.

- Concentración de tareas.

\footnotetext{
${ }^{7}$ Ley N ${ }^{\circ}$ 10.579. Año 2010, $16^{\circ}$ Edición. Páginas 10. Estatuto del Docente Provincial, Buenos Aires.
} Senado y Camara de Diputados de la Provincia de Buenos Aires sancionan con fuerza de ley. 
- El ejercicio de su actividad en las condiciones pedagógicas adecuadas.

- La consideración, por parte de las autoridades, de los problemas que afecten la unidad familiar.

- El uso de licencias reglamentarias.

- El goce de vacaciones reglamentarias.

- La libre agremiación para la defensa de sus intereses profesionales.

- El ejercicio sin trabas de todos aquellos que son inherentes a su condición de ciudadanos.

- La obtención de becas para su perfeccionamiento cultural y profesional y la consiguiente licencia si fuera necesario.

- La participación en el gobierno escolar, integrando los distintos organismos de la Dirección General de Escuelas y Cultura, prevista en este estatuto y leyes pertinentes.

- La percepción de la indemnización que, por enfermedad profesional y / o accidente sufrido en o por acto de servicio, establezcan las leyes que rijan la materia, sin perjuicio de otros beneficios y derechos que legalmente le puedan corresponder.

- Beneficiarse con los sistemas de asistencia y previsión social que se establezcan y participar en el gobierno que los rige de acuerdo con lo que establezcan las leyes orgánicas de cada entidad.

- El goce de una jubilación justa. 
Los establecimientos de enseñanza se clasifican de acuerdo al estatuto de la siguiente manera:

- Por niveles, modalidades y especialidades.

- Por el número de alumnos, grupos escolares, grados, secciones, ciclos, divisiones, cursos, especialidades o carreras.

- Por su ubicación, dificultades de acceso.

\section{Circular Número $7 / 1994^{8}$}

En la misma plantea atento a las situaciones planteadas y con el objeto de clarificar e informar acerca de la prevención de accidentes y la emergente responsabilidad civil, invita a reflexionar, remitiendo una serie de palabras y sus significados; como:

Imprudencia, imprudente, prudente, negligencia, negligente, perito, impericia, prever, prevención, prevenir, accidente, casualidad. También hace referencia a responsabilidad en el código civil, eximentes de responsabilidad, frente a un accidente, cómo actuar, datos de interés.

Informa sobre datos de interés, cobertura del seguro escolar: nivel inicial y primaria: Póliza $N^{\circ} 21671$, niveles post primaria y terciaria, No universitaria: póliza $N^{\circ} 65529$ ambas de la caja nacional de ahorro y seguro.

Contempla la circular el número de circulares vigentes para tener presente, consejos útiles y la bibliografía.

\section{Circular Técnica $2 / 2010^{9}$}

Refiere a las pautas para actividades de educación física en el medio acuático, manifestando que las prácticas acuáticas integran las propuestas pedagógicas en establecimientos educativos en todos los niveles y modalidades.

\footnotetext{
${ }^{8}$ Circular. Extraída del ABC. Dirección General de Cultura y Educación. Provincia de Buenos Aires. Modalidad Educación Física.1994

${ }^{9}$ Circular Técnica. Extraída del ABC, Dirección General de Cultura y Educación. Referencia sobre pautas para actividades de Educación Física en el medio acuático. 2010
} 
En aquellos establecimientos donde se desarrollen propuestas que contemplen actividades acuáticas o de enseñanza de natación se deberán considerar pautas, enmarcadas como propuesta educativa para la enseñanza de la natación en el proyecto institucional, debiendo responder a los diseños curriculares vigentes y contar con el aval del Inspector de educación física.

Cuando las actividades acuáticas integran una propuesta de salida educativa (resolución 498 / 2010, su implementación deberá respetar lo pautado en esta circular de acuerdo a cada nivel y modalidad.

En los casos de actividades acuáticas que se enmarcan como proyectos educativos en ámbitos como, colonias de vacaciones, planes educativos - recreativos de verano y / o propuestas pedagógicas en el medio acuático, en los centros de educación física, se deberá cumplir con lo pautado de acuerdo al nivel y o modalidad de los grupos implicados.

\section{Circular Técnica Conjunta Número $1 / 97^{10}$}

Objeto, pautar para el dictado de educación física en establecimientos de primaria. La supervisión y orientación de la labor específica, estará a cargo del cuerpo de los inspectores de la dirección de educación física, quienes informarán cada caso y en la forma que corresponda, al director de la escuela o la autoridad a cargo.

En la circular hace referencia al departamento de educación física, y a los accidentes; que deben llevar un libro, donde cada docente asentará lugar, día, hora del accidente, apellido y nombre de los / las alumnos/ as accidentados, curso al que pertenece, tipo de lesión, medidas adoptadas, hora y lugar de la atención médica, si la hubo. Se registrará notificación al director de la escuela y del padre / madre o tutor del alumno.

\footnotetext{
${ }^{10}$ Circular Técnica. Extraída del ABC. Dirección General de Cultura y Educación. Objeto, pautas para el dictado de Educación Física en Establecimientos de E.G.B.
} 
También el profesor debe informar a las autoridades del establecimiento, bajo acta de cualquier circunstancia ajena que afecte el normal desarrollo de la clase (Ej. accidentes, problemas de instalaciones, seguridad, etc.).

Respecto al dictado de clases fuera del establecimiento, cuando la educación física se dicte por ejemplo, (asociación de fomento, clubes, terrenos aledaños), el padre, madre o tutor, deberán ser notificados de ello por escrito, aclarando que el tiempo que medie entre la salida del turno escolar y el ingreso a clase estará bajo su responsabilidad y de la forma que éstos lo determinen. La clase tiene inicio y finalización en el lugar y horario establecido para ese fin.

Si ocurriera un accidente durante el desarrollo de la clase, el docente se abocará al auxilio del alumno y podrá dar por finalizada la clase, de no haber otro docente que pueda hacerse cargo de la misma. Luego comunicará inmediatamente lo sucedido y las acciones llevadas a cabo a los directivos de la escuela.

En los casos que el docente no concurra a prestar servicio, deberá informar al establecimiento con la suficiente antelación, a los efectos de notificar por medios fehacientes a los alumnos y padres de la suspensión de la clase.

Además de las suspensiones determinadas por las autoridades, los directores, podrán suspender las clases por malas condiciones climáticas, o deficiente estado de las instalaciones, Esta decisión podrá ser asumida por el asesor de departamento, o por el docente, constituido en el lugar de dictado de clases y comunicado inmediatamente a la autoridad del establecimiento, haciéndose responsable de la medida y señalando las causales.

La suspensión de las clases, indicadas en el párrafo anterior, sólo se hará efectiva cuando no exista un sitio alternativo, que permita el desarrollo de otro tipo de actividades que respondan a los contenidos del área o clases teóricas.

\section{Circular Técnica Educación Física Número $1 / 2010^{11}$}

\footnotetext{
${ }^{11}$ Circular Técnica Educación Física extraída del ABC. Dirección General de Cultura y Educación. Referencia: Encuentros Masivos Interescolares. 2010.
} 
Refiere a los encuentros masivos escolares, en el marco del acuerdo establecido entre la Dirección General de Cultura y Educación y la Secretaría de Deportes, ambos organismos de la Provincia de Buenos Aires, que establecen líneas de acción conjunta para desarrollar en todo el territorio bonaerense, uno de sus programas "Juegos Buenos Aires, 2010".

La organización, se elaborará un proyecto distrital de acuerdo a las características y necesidades del territorio, respondiendo a los lineamientos emanados por la jefatura regional y lo que prescribe el marco del plan educativo 2008 - 2011 de la Dirección General de Cultura y Educación.

Los destinatarios, alumnos de escuelas primarias, 2 do. Ciclo (5 to. -6 to.), alumnos de escuela secundaria, de modalidad especial. Los establecimientos que participen en dichos encuentros deportivos, deberán haber incluido en su proyecto institucional, los deportes antes mencionados.

Las jefaturas distritales elevan a la Dirección de Educación Física los avances y cronogramas tentativos del Proyecto a desarrollar, culminado el proyecto se confeccionará un informe cualitativo y cuantitativo del mismo enviando original a la Dirección de Educación Física, indicando cantidad de participantes por disciplina, categorías y sexo.

La Resolución Ministerial $\mathrm{N}^{\circ} 498^{12}$, como nuevo marco normativo y teórico que unifica criterios y facilite a los docentes y autoridades para la promoción y concreción de proyectos pedagógicos.

Las salidas educativas y de representación institucional cumplimentan las expectativas y constituyen para el profesor de educación física una oportunidad para abarcar proyectos pedagógicos institucionales. Con esta resolución se derogan las resoluciones $\mathrm{N}^{\circ} 426 / 06,1454 / 07,1457 / 02$ y toda otra norma que se oponga a la presente.

\footnotetext{
${ }^{12}$ Resolución Ministerial N ${ }^{\circ}$ 498. Marco Teórico y Normativo. Dirección General de Cultura y Educación. 2010
} 
Se aprueba esta normativa reglamentaria para la realización de salidas educativas y de representación institucional de alumnos en establecimientos de gestión estatal o privada de todos los niveles y modalidades del sistema educativo provincial.

Las actividades fuera del establecimiento escolar, en el marco de la salida educativa y de la salida de representación institucional, implica el cumplimiento de los requisitos enumerados en la resolución.

Los responsables, docentes para las instituciones de gestión estatal, en actividad, en relación de dependencia con la Dirección General de Cultura y Educación, comprendido en la Ley $\mathrm{N}^{\circ} 10.579$.

Para las instituciones, de gestión privada: personal docente programático y extra programático en relación de dependencia con establecimientos educativos de gestión privada.

Toda salida organizada de alumnos será comunicada al consejo escolar según lo pautado en el anexo tres de dicha resolución, por el seguro escolar, servicio alimentario centralizado y otros. En el caso de las Instituciones de gestión privada se deberá comunicar la salida a la compañía de seguro contratada, mediante formulario que decida la DIPREGEP.

La investigación sobre la responsabilidad civil en las prácticas del profesor de educación física en el patio escolar de la escuela determina que es necesario:

a) Poder analizar los discursos de los profesionales.

b) Explorar los impactos en esta época.

c) Revisar el estado actual de los patios.

d) Indagar sobre los datos del distrito de infraestructura y sobre las necesidades reales.

e) Denunciar falencias.

El encuadre legal relacionado con las prácticas del profesor pueden leerse en el estatuto del docente, las resoluciones, disposiciones, circulares generales, como 
también las normas legales. Muchas preguntas orientan a la investigación sobre la responsabilidad civil que espero poder responderlas.

Me pregunto:

¿Cuál es el estado actual del patio de las Escuelas Públicas del Distrito?

¿Cómo impacta la responsabilidad civil en las prácticas del Profesor?

¿Cuál es la percepción del profesional respecto al problema?

¿Cuál es el papel del Estado como Garante?

¿Quién garantiza que el Patio del Profesor esté en condiciones?

¿Qué dicen los actores sobre la problemática?

¿Qué prioridad tienen los Patios de Educación Física en la Provincia de Buenos Aires?

¿Cómo se organizan las autoridades del Consejo Escolar?

¿Qué aportes dan al Problema la Unión Educativa de Gestión Distrital?

La responsabilidad civil en el ejercicio cotidiano del profesor de educación física tiene exigencias y clases de derechos, que se pueden definir desde dos puntos de vista: objetivo (conjunto de normas que rigen las relaciones de los hombres en sociedad) y subjetivo (facultad que le permite a una persona exigir de otra determinadas prestaciones o al respeto de una situación determinada.

Regresando al concepto responsabilidad, es necesario conceptuar primero que son los derechos, los deberes y las obligaciones de las personas. Deber significa que está pendiente de una cantidad determinada de dinero. La prestación de un servicio, la ejecución de una obra o, en general, el cumplimiento de cualquier obligación. 
Obligación es el vínculo de derecho por el cual una o varias personas determinadas están obligadas a dar, hacer o no hacer algo respecto de otra u otras personas, en virtud de un contrato, cuasicontrato, delito, cuasidelito o ley.

Responsabilidad, sobre los conceptos "ut - supra" mencionados, cabe aclarar entonces, como se dijo, que, previamente, debemos diferenciar el concepto de responsabilidad de los anteriores citados.

Todo el sistema de la responsabilidad civil se fundamenta, principalmente en la culpa, la otra fuente tradicional de responsabilidad es el dolo, aunque actualmente deba adicionarse a la misma la teoría del riesgo creado. La culpa se divide en negligencia (sujeto deja de hacer algo que normalmente debería haber realizado para evitar las consecuencias dañosas) e imprudencia (en la que se realiza algo más de lo que debería haber hecho prudentemente). Se dice que el negligente da un paso menos que el que debe realizar y que el imprudente da un paso más.

Los temas legales no pueden trasladarse fuera del contexto del patio que los enmarca y sitúa en una realidad y los transforma en principios a respetar. Analizar la situación jurídica implica considerar en la escuela; aspectos históricos, sociales, regionales, culturales, económicos, políticos, etc. Que brindan el contexto necesario para efectuar la aplicación, interpretación, modificación y/o elaboración de normas jurídicas, que sustentan la existencia. ${ }^{13}$

El profesor de educación física, lo ubicamos dentro de la educación sistemática de la escuela, moviéndose en un marco normativo y a su vez ve la posibilidad de modificarlo o crearlo en su caso negándose, por desconocimiento o inseguridad a realizar el intento, emprendiendo un camino para ello.

Legislación se entiende por el conjunto de leyes por las cuales se gobierna un estado o se regula una materia determinada, entendiendo a la ley en sentido amplio, es decir todas las normas dictadas por la autoridad a quien esté atribuida esa facultad, ejemplo los derechos, los reglamentos, las ordenanzas, las resoluciones, etc. El término legislación significa conjunto de leyes o normas por las cuales se gobierna un estado o se regula una materia determinada.

\footnotetext{
${ }^{13}$ Universidad Nacional de La Plata. Facultad de Humanidades y Ciencias de la Educación. Ciclo Licenciatura en Educación Física.Problemas Jurídicos en el campo de las Prácticas Corporales. Material Bibliográfico Seminario. 2002 - 2003.
} 
Las leyes se han hecho para ser respetadas, caso contrario las mismas prevén sanciones para quienes la infrinjan. Estas pueden ser desde un apercibimiento (advertencia) pasando por una multa, suspensión, cesantía, hasta una pena de reclusión. Estos son elementos que diferencian al derecho de la moral, porque en el derecho de las reglas son obligatorias o impuestas coercitivamente, en cambio en la moral o ética, las reglas no son obligatorias.

La ley 13.688, de educación provincial regula el ejercicio del derecho de enseñar y aprender en el territorio de la Provincia de Buenos Aires, conforme a los principios establecidos en la Constitución Nacional y los tratados internacionales incorporados a ella, en la Constitución Provincial y en la Ley de Educación Nacional.

La educación es una prioridad provincial y constituye una política de estado para construir una sociedad justa respetando los derechos humanos y las libertadas fundamentalmente. En la Provincia de Buenos Aires, a través de la Dirección General de Cultura y Educación, tiene la responsabilidad principal e

Dentro de los fines y objetivos de la política educativa, tiene que garantizar en el ámbito educativo, la salvaguarda de los derechos de los niños y adolescentes establecidos en las Leyes Nacionales, 23.849, 26.061 y en las Leyes Provinciales 13.298, 13.634. De acuerdo con los términos del artículo 17 de la Ley 26.206 de Educación Nacional, la Provincial define como modalidades a la educación física. Los responsables de los niveles y modalidades conformarán un equipo pedagógico coordinado por la subsecretaría de educación.

La educación física es la modalidad que aporta al desarrollo integral y armónico de todos los alumnos según sus posibilidades de todos los alumnos según sus posibilidades incidiendo en la constitución de su identidad. La Dirección General de Cultura y Educación tendrá a su cargo la administración de la infraestructura escolar a través de un organismo técnico administrativo específico a fin de garantizar la construcción y habitabilidad de los espacios necesarios para el desarrollo de la enseñanza.

El estado provincial financia y a través de la Dirección General de Cultura y Educación, planifica, organiza y supervisa el sistema educativo, garantizando el acuerdo a la educación en todos sus ámbitos, niveles y modalidades, mediante la creación, regulación, financiamiento y administración de los establecimientos educativos de 
gestión estatal. El sistema educativo provincial según la Ley13.688 es el conjunto organizado de instituciones y acciones educativas reguladas por el estado que posibilitan la educación.

La Dirección General de Cultura y Educación reconoce a las instituciones existentes en el sistema educativo provincial que responden a formas particulares de organización diferenciadas de la propuesta curricular. La educación primaria, obligatoria de seis años de duración para niños a partir de los seis años de edad, organiza una unidad pedagógica.

En las escuelas primarias se encuentra el profesor de educación física que desempeña su tarea en los patios escolares. La educación física es una modalidad que aporta al desarrollo integral y armónico de todos los alumnos según sus posibilidades incidiendo en la constitución de su identidad.

Es responsable la educación física de articular las condiciones específicas de la conducción técnica - pedagógica y de organización en cada ámbito de desarrollo, de acuerdo con lo dispuesto por las respectivas direcciones de nivel y modalidad, así como disponer de propuestas pedagógicas complementarias a la educación común para los establecimientos educativos que desarrollen actividades específicas relativas a esta modalidad.

El gobierno y administración del sistema educativo provincial es una responsabilidad del poder ejecutivo provincial que la ejerce a través de la Dirección General de Cultura y Educación y que conforme a las disposiciones de la presente Ley, tiene idéntico rango al establecido en el artículo 147 de la constitución provincial y goza de autarquía administrativa, técnica y financiera, con capacidad para actuar en el ámbito del derecho público y privado.

La Dirección General de Cultura y Educación implementa la organización, administración y ejecución de la política educativa garantizando la utilización eficiente y transparente de los recursos presupuestarios y financieros, edilicios, humanos y didácticos como modo de asegurar el efectivo cumplimiento de lo establecido en la ley, conforme a lo estipulado en la Constitución Nacional y Provincial.

El sistema educativo provincial se organiza sobre la base de regiones educativas, concebidas como la instancia de conducción, planeamiento y administración de la 
política educativa. Cada región educativa comprende a uno o más de un distrito conforme a los componentes comunes que los agrupen y que son determinados por la propia Dirección General de Cultura y Educación.

La institución educativa es la unidad pedagógica del sistema, responsable de los procesos de enseñanza y de aprendizaje destinados al logro de los objetivos establecidos por la Ley. Para ello, articula la participación de las distintas personas que constituyen la comunidad educativa, directivos, docentes, padres, madres y/o tutores, niños, adolescentes, jóvenes y adultos, ex alumnos, personal administrativo y auxiliar de la docencia, profesionales de los equipos de apoyo que garantizan el carácter integral de la educación, miembros integrales de las cooperadoras escolares y otras organizaciones vinculadas a la institución.

El inspector jefe distrital es designado por el Director General de Cultura y Educación y depende técnica y funcionalmente del órgano general de inspección, siendo el superior jerárquico inmediato el inspector jefe regional. Constituye un grupo de trabajo con los inspectores de enseñanza, los consejos escolares, las secretarías de asuntos docentes distritales y otros actores, organismos e instituciones del distrito para planificar estrategias en el marco del planeamiento estratégico distrital.

El abordaje en este trabajo sobre responsabilidad civil en el escenario actual de la escuela primaria sobre esta problemática legal, tiene como objeto encauzar el abordaje a la responsabilidad civil que le compete al profesional de la educación física dentro y fuera de la institución escolar. Al finalizar esta investigación seguramente la forma de abordar esta temática no comenzará y finalizará con una documentación escrita o aislada, sino que intentaré significar a través del tiempo, que es importante hablar de un proceso de integración entre lo pedagógico y lo legal.

En el contexto escolar, desde el ámbito de la enseñanza, los docentes en general tienen la sensación de no estar suficientemente protegidos respecto a las consecuencias que se derivan de la responsabilidad civil por daños que se puedan ocasionar en las prácticas.

Al hablar de la responsabilidad civil, estamos hablando de prevención y prevenir no es más ni menos que anticiparse al peligro, al posible accidente, a lo que se pueda provocar en el patio en las clases de educación física. Pareciera que cargamos la 
mochila durante toda la vida, no solo como profesionales, sino como habitantes de una población determinada.

El director del establecimiento es el responsable de la Institución, al comienzo de cada año en la Escuela planifica la actividad, coordina con los directivos la "información de salud"14 y los registros de casos individuales en donde se especifica una contraindicación para realizar ejercicios físicos u otra observación relevante, relevamiento de campo en referencia a si existen agentes externos que pudieran ocasionar daños al alumnado, ante superior jerárquico deja constancia por escrito, los factores de riesgo para el desarrollo de la actividad (mástil, escaleras, tomacorrientes, patios en malas condiciones de higiene, etc.), la elección del lugar constituye una fuente de obligaciones a las que deberá responder como profesional experto en el tema.

Desde la Dirección General de Cultura y Educación con las resoluciones, normativas aplicables a la modalidad, pretenden contribuir a eliminar los miedos y que los profesionales como los alumnos puedan tener acceso a prácticas educativas en contacto con la realidad circundante. De un año a otro la provincia aprueba normativas reglamentarias aplicables bajo control de autoridad educativa, en establecimientos estatales o privados, de todas las direcciones docentes, niveles y modalidades del sistema provincial.

Las capacitaciones jurídicas en educación, sobre la temática "Responsabilidad Civil", como los documentos elaborados en los marcos de capacitación jurídica en educación llegan de la dirección provincial con los inspectores, estas normas que fundamentan la obligación de reparar los daños causados a otros que son tan antiguos como nuestro sistema jurídico. Desde que existen escuelas como profesores de educación física, tanto los alumnos como sus padres o cualquier tercero que sufran un daño originado en el quehacer educativo o causado por las "cosas" de la escuela, pueden demandar resarcimiento.

A pesar de que las normas ahora favorecerían al docente directivo, la preocupación por las consecuencias de hechos de responsabilidad aumenta respecto de épocas pasadas y se instaló como un problema cotidiano. En la actualidad es frecuente la consulta a los abogados y la concreción de demandas por daños, a veces en casos de responsabilidad muy clara, en las que por sentido común se acordaría con la justicia 
del reclamo y otras veces, es demandado aquel docente que tuvo el infortunio de que ocurriera una desgracia imprevisible.

El saber sobre responsabilidad civil es técnico y su contenido jurídico debe ser abordado científicamente. Cada caso sobre daños en el patio escolar lugar de identidad del profesor de educación física es especial y merece un análisis particular en el cual confluyan algo más que las normas del código civil.

La preocupación de los docentes de educación física no se resuelve si ellos saben más sobre responsabilidad civil sino con la práctica profesional y responsable de la función sobre la cual conoce cada uno por formación y experiencia.

Son derechos del personal docente titular del establecimiento educativo, el ejercicio de su actividad en las condiciones pedagógicas adecuadas, la consideración por parte las autoridades, de los problemas que afecten la unidad familiar, el ejercicio sin trabas de todos aquellos que son inherentes a su condición de ciudadanos, la participación en el gobierno escolar, integrando los distintos organismos de la Dirección General de Escuelas y Cultura previstas en el estatuto y leyes pertinentes.

El infringir reglas del derecho, estas accionan en contra de manera de impedir el acto si todavía es tiempo, o de anularlo y restablecerlo bajo su forma de norma si es acto consumado y reparable, o de hacer expiar si no puede ser reparado de otro modo.

Seguramente podríamos distinguir dos sentidos del término sujeto, relacionado con la historia, por un lado, un sujeto, sometido al control y la dependencia de otro y aquel ligado a su propia identidad de las prácticas y el conocimiento de sí. Una observancia epistemológica sobre quien somos, que hacemos, saliendo del sentido común con distintos paradigmas.

Una epistemología que permita reconsiderar, las relaciones existentes entre el saber y el poder. Las decisiones importantes en lo institucional, lo local, lo regional y lo provincial forman parte del espacio estratégico. El propio saber tiene su origen en la comunidad, en el propio poder que tiene y por tanto es su propia posición.

La resolución ministerial provincial, de la Dirección General de Cultura y Educación establece el uso compartido de los edificios escolares que será dispuesto mediante acto administrativo, por el inspector jefe distrital, fundado en las necesidades de la 
prestación del servicio, con intervención previa del consejo escolar y del inspector correspondiente, quienes producirán informes técnicos referidos a sus áreas específicas.

En ningún caso, un inmueble en que funcione un servicio educativo será considerado como perteneciente al mismo o a un nivel, modalidad o especialidad de la educación, siendo competente para decidir sobre el destino del mismo el funcionario que se señala.

Los Directores de cada servicio educativo serán los responsables de articular y coordinar los servicios educativos que funcionen en el edificio escolar, como asimismo garantizar una adecuada convivencia. Las necesidades de adecuación edilicias que debieren efectuarse serán elevadas, previa intervención del consejo escolar, al inspector jefe distrital quién dará intervención al delegado de infraestructura escolar, con cuyo informe determinará la procedencia de las mismas.

La responsabilidad civil como problema jurídico en el campo de las prácticas corporales, es tratado en el contexto de la escuela, mas precisamente en el patio, lugar de actividad cotidiana del profesional de la educación física. La función se encuentra normalizada a partir de la norma fundamental que transparenta, es gradual, orienta y normaliza.

La obligación de reparar los daños causados es importante a la hora de reflexionar en las prácticas profesionales del patios escolar, por lo que anticiparnos al daño con prevención en el diagnóstico, diseño, ejecución de las acciones como profesional es preocuparse no solo por el alumno sino por las posibles consecuencias de hechos que son de suma importancia en la institución escolar.

Ante el desconocimiento de las normativas, nos tenemos que informar, conocer y saber del contenido jurídico que debe ser abordado científicamente, mereciendo un análisis que nos lleva más allá del estatuto docente como del código civil. La práctica profesional y responsable real de práctica motriz en el patio escolar debe ser conocida.

La inseguridad, el no resguardo, desvía la atención de aquello que considero debe tenerse en cuenta como formadores en la cotidianeidad de la tarea educativa, que involucra la participación de un número de actores; alumnos, docentes, directivos, 
administrativos, porteros, peones de cocina, otras personas que concurren diariamente al establecimiento cuyo propietario resulta, responsable de la seguridad de todos ellos.

La práctica profesional y responsable de la función de la cual debe conocer el profesional de la educación física por la formación y experiencia debería ser preocupación actual en resguardo de la responsabilidad civil. Asesoramiento también es importante para ser requerido ante las áreas legales de la rama respectiva.

\section{Capitulo IV}

\section{1. "Obligaciones Profesionales"}


El capítulo anterior tratamos los encuadres legales, normativas y circulares. Retomamos este con las obligaciones profesionales, las prácticas del profesor, la función en la órbita jurídica y la clasificación. También iniciamos el trabajo de campo en la escuela.

\section{2. "Las prácticas profesionales del profesor"}

La función de los profesores de educación física parece ajena a la órbita jurídica, en la sola aparición del conflicto se hace visible. Los profesores que trabajan en los patios de las escuelas se desempeñan la mayor parte de las veces sin tener en consideración lo expuesto y en general por desconocimiento de los preceptos que nos regulan en el accionar. Funda su accionar olvidando el basamento jurídico subyacente $y$ actuando a veces en forma equivocada por desconocimiento, no justificado, de sus derechos y obligaciones.

En las visitas a las escuelas donde el profesional trabaja en patios sin condiciones mínimas de seguridad, en playones sin acondicionar, como también en lugares poco apropiados para la actividad de la educación física. Si hablamos de los profesores en los patios seguros obedientes a la normativa, sería circunscribirnos, al conocimiento de la misma y su ubicación como problemática de reflexión, entendemos que la sociedad jurídicamente organizada requiere hoy en la actualidad de un entramado legal que facilite la convivencia y evite conflictos como también que prevea sanciones cuando las conductas de los individuos así lo exijan. ${ }^{15}$

El profesor de educación física se mueve dentro de un marco normativo y a su vez ve muchas veces la necesidad de modificarlo o crearlo en su caso negándose o dando permisos, por desconocimiento o inseguridad a realizar el intento, emprendiendo un camino para ello. Los patios donde se desenvuelven las prácticas profesionales al verlo no muestran un estado de mantenimiento como también carecen de elementos o materiales adecuados.

La clasificación de las normas nos enseñan diferencias sustanciales entre las mismas que a su vez nos mostrará su origen, fundamentación, ideología que la sustenta, etc., elementos necesarios para efectuar críticas y propuestas.

\footnotetext{
${ }^{15}$ Problemas Jurídicos en el campo de las Prácticas Corporales. Material Bibliográfico. 2002 - 2003. Adolfo Bertch.
} 
Es el deber de resarcir los daños causados y los perjuicios provocados por sí o por un tercero, por el que se debe responder. Contractual, si originada en el incumplimiento de un contrato válido y extracontractual, cuando deriva del hecho de haberse producido un daño que es ajeno a toda vinculación convencional por culpa o dolo. Por el hecho propio, cuando es ocasionada por hechos en omisiones propias y por el hecho ajeno, cuando es ocasionado en hechos en omisiones ajenas (padres / hijos, tutores / menores y directores del establecimiento.

Régimen: El régimen aplicable a esta responsabilidad especial, se distingue entre los daños ocasionados a los participantes de la competencia deportiva, y los daños que sufran los extraños a ella (espectadores o simples terceros).

Daños a participantes, distintos casos dentro de la problemática que generan los daños sufridos por los participantes de una prueba deportiva, debemos -a su vezdistinguir los siguientes casos:

1 - Daños causados por un participante a otro.

2 - Daños atribuibles a la entidad deportiva.

Daños a extraños: Cuando el daño lo sufre un tercero ajeno a la competencia deportiva, está fuera de discusión que la responsabilidad, en caso de nacer, tiene fuente extracontractual.

El sustantivo profesional engloba un doble concepto. La doctrina tradicional ha tomado en cuenta este sentido estricto, que corresponde al denominado profesional liberal. Se debe tener en cuenta en las organizaciones en caso de delegaciones, representaciones si actúan como dependientes de la Provincia de Buenos Aires (Dirección General de Cultura y Educación), por las imputaciones de faltas "in eligiendo"'in vigilando" sobre los posibles alcances de las indemnizaciones pretendidas.

El ser es alguien que posee inteligencia y voluntad, por lo que puede actuar ejerciendo sus facultades. Es un ser social el que vive agrupado a sus semejantes, vive en sociedades y por lo tanto, su libertad debe ser ejercida con el límite del respeto que 
debe a la libertad. En la sociedad se establecen normas que serán las garantías para que cada habitante se le asegure el ejercicio de las facultades. Los derechos de uno terminan donde comienzan los derechos de los otros.

La norma es una pauta de conducta o manifestación social, son la descripción de una forma de comportamiento ante una situación. Todas las normas tienen en su estructura una hipótesis y una consecuencia. Están las normas morales y las normas jurídicas. Las primeras establecen reglas de conducta individual, que no son de aplicación obligatoria, las segundas son reglas establecidas por las autoridades públicas para regir las relaciones de los hombres entre sí y de estos con el estado.

Las normas jurídicas forman parte del ordenamiento jurídico de un estado determinado, son obligatorias, fijando los principios y modos de resolver los conflictos que se originan en el ámbito de estas relaciones. Todos los profesores de educación física en el desarrollo de las prácticas, tienen responsabilidad frente a sus alumnos a su cargo.

Al ver los patios de los profesionales en la actualidad donde los profesores cumplen con la tarea docente, uno pudo apreciar que algunos actúan con negligencia: (falta de cuidados en el patio, abandonan a sus alumnos en clase, descuidan al mismo, olvidan u omiten, como la imprevisión.). Asimismo la imprudencia (falta de prudencia, actitud temeraria que pone en riesgo o peligro a los alumnos a su cargo o a terceros.). La impericia es también la negligencia o la imprudencia llamada también la mala praxis.

En la actividad los profesores son públicos y toman las medidas preventivas dentro y fuera del patio de la escuela, en cualquier práctica o situación de las personas, la prevención es lo que evita las posibles consecuencias dañosas que se producen por la falta de cuidado. Es importante contar con los medios adecuados para realizar la misma, porque la consecuencia de no tenerlos es una de las causales de siniestros más importantes.

Es recomendable redactar en cada escuela y con la participación de directivos como de los docentes, los reglamentos que identifiquen los riesgos que puedan prevenirse con medidas concretas y colaboración de los padres. Es importante que los reglamentos sean firmados por los padres, integrantes de la cooperadora, directivos, docentes y alumnos. 
Denunciar los patios por parte de los profesores en las escuelas donde trabajen, los pisos deslizantes, escaleras sin resguardos, paredes con aristas cortantes, puertas y ventanas con paños de vidrios grandes, materiales inadecuados, deterioro de mobiliario, falta de aprobación de artefactos o elementos por autoridad competente, falta de disyuntores o matafuegos adecuados, etc.

Agregar la revisión periódica de sistemas eléctricos e instalaciones de gas, los disyuntores, análisis de agua que se utiliza en la escuela, inspecciones de bromatología en escuelas que brindan servicio de comedor, etc. Si las clases de educación física las dictamos en el polideportivo solicitar que reparen, mantengan y/o construyan cercos perimetrales y enrejados. Mantener o solicitar instalación de columnas de alumbrado exterior, denunciar la rotura y/o falta de tapas del sistema cloacal, revisar los medidores y tapas de cajas del sistema de gas.

Exigir el adecuado mantenimiento de juegos infantiles y que estén construidos sobre pisos de arena, ajustándose a las dimensiones de la reglamentación vigente. Procurar la limpieza periódica de patios y espacios externos (eliminar vidrios, latas, alambres, etc.). Solicitar la instalación de rampas para discapacitados, como también pasamanos en las escaleras de acceso a distintos niveles. Al profesor de educación física se le hace necesario conocer principios, fundamentos y conceptos del derecho laboral a quienes tiene la responsabilidad de dirigir las instituciones educativas.

Tanto el empleador como el trabajador deben cumplir lealmente sus obligaciones, la tarea del profesor implica connotaciones que pocas profesiones abarcan. Por un lado el continuo avance de las técnicas cómo de las teorías, por otro el cambio constante de la sociedad y por ende de los destinatarios de la educación y un alto nivel de exigencia como de compromiso por el significado de la tarea, valorada socialmente.

Si hablamos de prevención del daño se debe aclarar que no es tarea exclusiva de la responsabilidad civil. Son eficaces las regulaciones administrativas (por ejemplo las normas contra incendios, obligación de utilizar cinturones de seguridad, las normas de las construcciones, etc.) y también las sanciones penales. Lo que no quiere decir que la responsabilidad civil, modernamente no pueda ser vista como un instrumento más de prevención de los daños.

Podemos hablar de dos aspectos muy importantes a tener en cuenta: el primer aspecto preventivo podemos llamarlo económico, pero también puede ser enfocada 
desde el ángulo jurídico, de la responsabilidad civil, porque el derecho penal y el derecho administrativo son también instrumentos útiles de prevención. Para que exista responsabilidad civil debe haber daño.

También tiene la responsabilidad civil una función preventiva, es decir de actuación de anticiparnos o adelantarnos antes que ocurra el daño, de evitación de que el perjuicio suceda.

¿Qué es entonces lo que distingue la responsabilidad civil de otras responsabilidades impuestas por el derecho se pregunta a menudo los profesores de educación física?

En primer lugar en que la responsabilidad civil debe existir daño, lo que puede no acontecer en el derecho penal o en el derecho tributario con las infracciones formales. En segundo lugar la responsabilidad civil no es excluyente de otras responsabilidades y bien puede afirmarse que es complementaria. Por ejemplo si el delito penal ha causado un daño este debe ser indemnizado, lo mismo que el hecho por el cual se priva de la patria potestad al padre, también puede generar obligación de indemnizar al hijo (malos tratos, por ejemplo).

Podemos decir que la responsabilidad civil no es subsidiaria, es decir no se impone luego de las otras sanciones o cuando éstas no se han impuesto, por lo que puede coexistir con la responsabilidad penal, ética, administrativa, sin dar lugar a planteos. Incluso la responsabilidad civil puede ser previa.

El derecho es una herramienta indispensable para que la convivencia humana sea posible, lo que se logra instaurando un sistema de controles variados, que se expresan mediante normas, mandatos, prohibiciones, costumbres, etc., los que en caso de no ser respetados generan en el sujeto el deber de responder. En el estado actual de la evolución de la historia del hombre la responsabilidad civil y la penal se han separado en casi todos los sistemas jurídicos del mundo. No siempre el ilícito penal fue distinto del civil y las consecuencias de los hechos.

La responsabilidad civil atraviesa las prácticas de los profesores de educación física. Los análisis de los discursos como los problemas en los patios nos permiten explorar aún más en esta época los conceptos de norma y ley en particular. Lo establecido por la ley entre lo permitido o lo prohibido, como también la norma expresa una cierta gradualidad entre un más y un menos. 
¿Por qué un tema que preocupa tanto a los profesores como la responsabilidad civil se trata generalmente frente al hecho consumado?

Si es un tema preocupante de actualidad debemos tener en cuenta: el lugar, las circunstancias, el tiempo, el contexto y brindarles prevención. Es justamente lo que no muestran los patios.

La práctica física - deportiva supone en sí misma una actividad riesgosa por los diferentes componentes que la determinan: manejo de móviles, delimitación de los espacios, las edades de los participantes, condiciones meteorológicas, y sobre todo, por la velocidad de los ejecutores. La seguridad de instalaciones donde los profesores practican se ha convertido en una preocupación constante durante los últimos años.

Primeramente intentar concientizar, también sensibilizar y prevenir para adelantar anticipando algún posible daño que pueda ocurrir. En la actualidad pareciera que se espera el hecho para poder actuar. Los riesgos aparecen en el profesor de educación física: como riesgos aparentes, riesgos subjetivos y riesgos reales objetivos. Determinadas actividades de ocio o recreación, muy reconocidas invitan a la realización de actividades denominadas de riesgo

En educación física brindar a los niños, adolescentes, jóvenes y adultos una propuesta pedagógica disciplinar, opcional, sistemática promoviendo modos de organización que garanticen dinámicas democráticas, forma parte de los códigos. ${ }^{16}$ La ley regula el ejercicio del derecho a enseñar y aprender en la provincia de Buenos Aires, conformes a los principios establecidos en la constitución nacional, y los tratados Internacionales incorporados a ella, en la constitución provincial y en la ley de educación nacional.

La asistencia a la escuela como la edad mínima para abandonarla está fijada por ley. El profesor no puede desconocer sus derechos y obligaciones en las prácticas escolares, regulan su accionar desde que inician la tarea hasta su finalización como un soporte a cada decisión.

Está ubicado en la educación formal sistemática que se mueve dentro de un marco normativo. Al hacer mención a las leyes nos introducimos dentro del campo jurídico, del derecho, como conjunto de reglas que el profesor no debe desconocer que rigen

\footnotetext{
${ }^{16}$ Ley 13.688, ley de Educación Provincial.
} 
entre el profesor y el alumno dentro de la escuela. Constituyen el deber ser y el deber hacer en la institución educativa.

Dichos códigos se han hecho para ser respetados, caso contrario se prevén sanciones quienes las infrinjan. Cada norma forma su validez en otra norma de grada superior. Una norma es válida si su contenido coincide con el derecho natural. La educación física es una práctica social, donde hay sociedad hay derecho, aún en agrupaciones más primitivas, los integrantes deben acatarlas, para coexistir y respetarse, porque convivir implica límites y reglas de manifestaciones o expresiones recíprocas. Ciertos acciones están prohibidas y los demás permitidos. Las violaciones de las prohibiciones son sancionadas por los grupos. Por tal motivo el derecho es amplio y tiene que ver con las conductas humanas, las normas y/ o conjunto de las mismas. ${ }^{17}$

Las normas integran válidamente un ordenamiento jurídico, son válidas cuándo han sido dictadas por el órgano mediante el procedimiento y cuyo contenido debe ajustarse a normas superiores. Estas normas se interrelacionan de forma tal que algunas comparten un mismo plano jerárquico mientras que otras están en relación de subordinación respecto de otras superiores. Nuestro sistema convive con ordenamientos jurídicos yuxtapuestos (el nacional y el provincial). En la cima de las jerarquías de las leyes, están la constitución nacional y provincial que establece la forma de gobierno. La constitución nacional ha reservado la atribución del dictado del código civil. La aplicación de las normativas exige su previa interpretación.

La constitución es la ley fundamental de la organización estatal, determina los contenidos de las leyes y regula la creación de las mismas. Es la ley superior y a partir de ella surgen otras leyes que no pueden ser contradictorias. La norma general regula los actos y las relaciones humanas, aplicables en tiempo y lugar, con una ley que mande o se prohíbe o permite una cosa. El decreto da aclaración acerca de las Leyes pero no puede ampliar el contenido de las mismas. La resolución, es una orden emanada de una autoridad superior a los dirigidos, generalmente son por escrito. La ordenanza, es una disposición dictada por el municipio para el gobierno de la respectiva ciudad.

Las normas regulan la conducta de las personas en un tiempo y lugar determinado, las actividades que desarrollan los profesores en el patio si reflexionan sobre sus prácticas, se darían cuenta que en la gran mayoría de las normas jurídicas las

\footnotetext{
${ }^{17}$ Código Civil. República Argentina. Normativa
} 
desconocen. Las normas jurídicas determinan cuales son los actos permitidos o no realizables. Convivimos en un modo permanente con normas de toda especie que se encuentran relacionadas entre sí y configuran un ordenamiento.

Como personas físicas (sujeto de derecho), estamos obligados a respetar y cumplir con las normas de carácter general (nacionales), civiles, penales, constitucionales, laborales, administrativas, ley del deporte, ley del doping, etc. También estamos obligados a respetar las normas provinciales, municipales, otras. Cuando viajamos a un encuentro distrital, regional y provincial dirigimos el equipo de la escuela y estamos representándola. Tenemos normas a respetar, propias (estatuto), y otras que reglan la conducta a cumplir dentro y fuera de la institución mientras la representamos.

Las acciones humanas son susceptibles de ser consideradas en relación, entre los sujetos o entre estos y las cosas, o entre estos y el estado. Para el derecho las conductas serán lícitas o ilícitas, permitidas o prohibidas, porque cualquier conducta siempre tiene relevancia jurídica. El derecho esta siempre desde el momento en que hay un grupo social en la organización. Este conjunto de reglas de conducta que deben cumplir obligatoriamente y cuya observancia puede ser impuesta por la autoridad legítima. Algunos sostienen que la garantía de las condiciones de vida en la sociedad, está asegurada por el poder coactivo del estado.

El derecho objetivo, sería la existencia de principios y normas que regulan la convivencia humana. El derecho subjetivo, sería la facultad que las personas físicas o jurídicas tienen para realizar ciertos actos permitidos que la ley no prohíbe.

No hay derecho si no puede ser exigido coactivamente, la noción de derecho es considerado como una forma de control social. En la escuela reciben los profesores las circulares que es una notificación que se da generalmente entro los pares de educación física, orden dirigida por una autoridad a todos o algunos. También están las directivas que son de aplicación exclusiva para un establecimiento educativo, por ejemplo la dada por la Directora de la escuela.

Interpretar es buscar sentido a las normas y el valor para ser aplicada a las relaciones jurídicas, teniendo en cuenta las circunstancias del caso. Las fuentes del derecho son: la ley, la jurisprudencia, la costumbre y la doctrina. La ley en sentido amplio se entiende como normas jurídicas reguladoras de los actos y de las relaciones humanas, 
La costumbre es la conducta repetida, la costumbre jurídica es la repetición de conducta en interferencia subjetiva.

La jurisprudencia es la interpretación que de la ley hacen los tribunales para aplicarla a los casos sometidos a su jurisdicción. La doctrina es el conjunto de tesis y opiniones de estudiosos del derecho, que explican y fijan el sentido de las leyes o sugieren soluciones.

Hay tres elementos de las relaciones jurídicas que son: el sujeto, el objeto y la causa. El sujeto puede ser activo o pasivo, el objeto es el contenido de la prerrogativa y contraer obligaciones y la causa, es el hecho del cual deriva. La persona es el ente susceptible de adquirir derechos y contraer obligaciones. Las clases, personas de existencia visible, todos los entes que presenten signos característicos de la humanidad.

\section{Trabajo de campo}

El trabajo de campo como marco reflexivo para la interpretación de la técnica, ámbito donde se obtiene la información y los procedimientos intentan responder a los objetivos como a las preguntas de investigación. Los actores interpretaron la realidad social y en el sentido a sus expresiones son inseparables al contexto.

Los actores entrevistados son los informantes respecto a la problemática de la responsabilidad civil, manifestando los que piensan, dicen y hacen con respecto a la problemática jurídica. Como profesional de la educación física integrando las reuniones profesionales, visitar y charlar con los profesores, tomar mate con los auxiliares, asistir a clases de profesionales, entrevistar a los abogados, maestros, directivos, escuchar reuniones de la problemática me permiten observar participando de la temática.

Detectando situaciones en que se expresan y generan situaciones sociales y culturales entre los actores. Observación sistemática y controlando todo lo acontecido participando en varias actividades de la población investigada. Observar y registrar los datos en los distintos momentos y eventos de la vida social. Hacer, conocer, participar, observar, mantener distancia e involucrarse en las prácticas profesionales del profesional. 
La importancia del trabajo de campo diferenciando entre lo que la gente hace y dice que hace, pues en este caso de la responsabilidad civil aparece invisible a las costumbres y a los vicios sociales. A veces pareciera imposible estudiar a un grupo sin ser parte de él. Al ser participante observador se desempeña en varios roles locales, explicitando el objetivo de la investigación.

La entrevista realizada a los actores, permiten conocer el parecer respecto al problema legal, el soporte jurídico de cada prácticas en el patio escolar, el conocimiento de la norma legal vigente y su aplicación a la realidad concreta actual. El sentido de la vida social se expresa particularmente a través de los discursos que emergen constantemente en la vida diaria, de manera informal por comentarios, anécdotas y conversaciones.

Utilización de estrategias para hacer que los profesores hablen sobre lo que saben, piensan y creen, una situación en la cual permite explorar los impactos de la época, al interrogarlo como también me permitirían revisar el estado actual de los patios escolares indagando sobre los datos existentes del distrito de infraestructura y sobre las necesidades reales.

La información sobre el sentido de los hechos, sentimientos, opiniones, emociones, las normas de acción y manifestaciones como expresiones de la conducta. Las entrevistas es importante poder obtener información y datos que dan acceso a los hechos, hablan del mundo externo, respuestas de los informantes que cobran sentido por su correspondencia con la realidad.

Obtener información verificable, la entrevista como relación social de manera que los datos que provee el entrevistado son la realidad que este constituye con el entrevistado el encuentro, con flexibilidad manifestada en una estrategia para descubrir e identificar los contextos en virtud de los cuales las respuestas cobrarían sentido. Preguntas relevantes, que pretenden distinguir lo principal de lo secundario, lo que proviene de sus propias inferencias y preconceptos, contribuyendo a modificar y relativizar su perspectiva sobre el universo cultural.

Intentando con la metodología focalizar y profundizar, ampliar, sistematizar el material obtenido. Entrevistando a los profesionales como proceso en el que se pone en juego una relación que las partes conciben de manera distinta. Teniendo un inicio, 
desarrollo, un cierre, puede dar comienzo como cualquiera, en cualquier lugar, con o sin concertación previa, con o sin una duración estipulada.

La investigación cualitativa permite usar la narración, analizando los discursos, las estadísticas como también los enfoques, métodos, técnicas, encuestas y observación participante del proceso de enseñanza - aprendizaje en la modalidad educación física que estaría atravesado por la responsabilidad civil en las prácticas del profesional que impactarían en definitiva en la calidad de la clase del alumno.

La metodología escogida como cualitativa, al elegir un tema que me intereso conocer, que me gusto, en el que me involucre, en su momento me preocupó y ahora en el presente aún más que me movilizo logrando angustias y placer en otros momentos. El proceso de reflexión con temas de profundo análisis que me permitió planificar la tesis y profundizar el estudio de la misma.

Cuando se quiere sacar de los hechos la problemática y algunos conceptos que nos permiten construir o analizar, se corre el riesgo de sacar de sus dichos de cada entrevistado informaciones distintas. Seguramente no basta con escuchar a los sujetos, registrando las palabras e informaciones, para explicar los hechos de responsabilidad civil en las prácticas del mismo en el patio. No fue fácil tomar distancia de los hechos o daños en las clases del patio escolar. ${ }^{18}$

Las entrevistas giraron en torno a la confianza, la curiosidad y la naturalidad. Un respeto por el proyecto y confianza en llevar adelante la tarea de llevar a cabo la investigación. Un posicionamiento del tema de investigación llevado a cabo durante el trabajo trasmitiendo con claridad la posición. La responsabilidad civil en las prácticas del profesor necesitó esclarecer o descubrir ciertos aspectos del contexto escolar.

Permitió hallar elementos, causas, distintas explicaciones de los Directivos, Profesores, Abogados, otros que construyo nuevos conocimientos, actualizando datos existentes logrando en el escritor un posicionamiento sobre la temática para profundizar los temas en cuestión para transmitir claridad en la comunicación a medida que fue desarrollando el trabajo de investigación. El problema de la responsabilidad civil fue expuesto como problema a investigar en todo momento, el armado del marco teórico para llevar adelante la situación y las conclusiones seguramente producirán conocimiento.

\footnotetext{
${ }^{18}$ Bourdieu, Pierre. El oficio del sociólogo. 1995.
} 
Investigar es des - cubrir algo que está tapado. ${ }^{19}$ Investigar algo no conocido. Comenzando con el estado de arte, en torno a las posibles investigaciones sobre el tema de responsabilidad civil. Permitiendo en el transcurrir del trabajo que es un tema novedoso e importante que no ha sido explotado. Profundice la investigación de la licenciatura en educación física sobre la responsabilidad civil en los Centros de Educación Física.

El tema me involucró, me preocupo y movilizo en todo momento apareciendo problemáticas que se cruzan, debates, saberes, que permitieron construir el trabajo. Los motivos para elegir el tema son muchos; las causas, hechos relacionados con el tema, falta de normativas, reglamentaciones, motivos que por circunstancias, tiempo y espacio no resuelven la situación actual y las inquietudes personales como profesionales. Elegí el contexto del patio escolar donde el profesor desempeña su tarea de educación física y pregunté distintos interrogantes como ¿Qué quería saber de la responsabilidad civil que no conocía?

Como el tema de investigación es grande y encierran distintas problemáticas traté de ir desmenuzando cada una de las entrevistas para desentrañar lo no conocido, saliendo a buscar información en los distintos escenarios del problema. También me fui instalando como observador de las escuelas sobre la cultura escolar y la problemática del lugar, su seguridad, el tiempo de clases y las circunstancias de hechos.

Apareció el momento de la elección de la metodología del trabajo, con un corte cualitativo Entender y comprender lo que quisieron decir los directivos, docentes, abogados, licenciados, en escenarios diversos, me demando observar y registrar cada acontecimiento de la realidad. Recopilar cada dato no fue sencillo, interpretar las entrevistas como plasmarlas en los escritos un dato menor. Los distintas circunstancias de los hechos como de realidades múltiples son sujetos con relaciones distintas fueron produciendo y construyendo el campo del saber.

La metodología de investigación cualitativa me llevo a las entrevistas y observaciones en los patios en distintos contextos. Los alcances fueron inimaginables a la hora de recopilar datos como documentos interpretando lo que cada uno dijo interpretando el

\footnotetext{
${ }^{19}$ Deconstrucción de una labor arquitectónica”, Artículo, Gabriel Cachorro, 2002.
} 
verdadero sentido de la entrevista. Palabras claves articuladas conformaron las categorías teóricas. ${ }^{20}$

Analizando cada una de las entrevistas, intente desmenuzar las respuestas de los informantes respondiendo preguntas relacionadas con la responsabilidad civil en las prácticas del profesor en el patio escolar. Aparecieron las categorías teóricas como "escuela", "normativa”, "sujeto", “Identidad", "código”, entre otras.

Las categorías sociales pudieron construir los discursos de los sujetos entrevistados como observados en el patio, en el desarrollo profesional, categorizando las prácticas en el tiempo, espacio y circunstancias de hechos del pasado produciendo datos de real importancia para la tesis.

Aunque la observación constituye el corazón de la etnografía pura, la mayor parte del trabajo de investigación educativa realizada en Gran Bretaña se ha basado principalmente en las entrevistas. ${ }^{21}$ Modo de descubrir personas y de recoger información de problemáticas y acontecimientos como hacer que las cosas sucedan. La confianza en cada entrevista es fundamental, la curiosidad en torno a datos de importancia sobre el tema y la naturalidad son importantes.

Todas las personas entrevistadas tienen valores e intereses por lo que estar maduro para dar claridad a las opiniones, actitudes y gustos contra lo que algunas personas podrían sentir algo de resistencia fue importante tomar distancia ante estos acontecimientos. El deseo de saber y conocer las opiniones como las percepciones de los que accedieron a las preguntas para conocer su opinión, las historias como los sentimientos fue motivador para quién escribe para no tener muchas dificultades en la preparación y conducción de las entrevistas.

Fue importante descubrir a medida que pasaban las entrevistas los pensamientos de cada informante como ser espontáneo para no interferir y recoger información como testimonios de los distintos acontecimientos captando en lo que cada uno tenía en su interior. En algunos casos la necesidad de transmitir conocimientos de hechos de responsabilidad civil ocultos en su interior, luego de la entrevistas dejo en el sujeto algo de tranquilidad por el hecho de poder expresarlo.

\footnotetext{
${ }^{20}$ Delgado, J y Gutierrez J. (1995). Métodos y técnicas cualitativas de investigación en ciencias sociales.

${ }^{21}$ Peter Woods. 1986. La Escuela por dentro. La etnografía en la investigación educativa.
} 
Los lugares de las entrevistas fueron diversos que implicaba una formalidad, actuando libremente, abierto, democráticamente e informal en algunos aspectos. Cada uno se manifestó accesiblemente a las preguntas, en ningún caso fue impenetrable. No hubo presión y si tolerancia con organización e intercambio de saberes. En algunos casos fue menos formal, más relajados, menos competitivos como estimulantes con sentido de comunicación y comunidad.

Dichas preguntas se realizaron, en contextos diferentes: autos, casas, patios, escuela, universidad, cafés, centros educativos, otros. A veces las entrevistas más formales fueron programadas como tal, aunque en algunas circunstancias se dio lugar a un cierto poder de relaciones. En otros ámbitos las entrevistas dieron lugar también a la observación, principalmente buscando signos de desarrollo, indicios como escalas de prioridades en la perspectiva del entrevistado y también a la emoción del mismo por los dichos. Una pregunta dio lugar a formularla de muchas maneras, empleando términos claves del entrevistado.

Así como la entrevista puede compararse con la observación participante, la realización de un registro puede compararse con las notas de campo. El grabador como elemento magnífico pudo registrar cada respuesta del sujeto, no teniendo otra manera de reconquistar con plenitud, fiabilidad de palabras, lenguaje de cada actor. De este modo libera al entrevistado de una difícil tarea y le permite concentrarse en otras.

Escogí la metodología cualitativa porque me permitió describir y comprender el sentido de las acciones y prácticas del profesor en el patio escolar. Porque hay una enorme gama de variaciones lo que permitió identificar una parte de variación, homogénea y estudiarla en forma completa. Trate de abordar el dominio completo, reconociendo las diferencias y describiéndolas.

Algunas entrevistas con enfoque bibliográfico dieron respuestas a relatos de vida, testimonios $u$ otros. Otras fueron con preguntas en profundidad sobre el tema de la responsabilidad civil en el patio escolar.

Esta técnica cualitativa sirvió para descubrir los significados compartidos por un grupo de profesionales dentro de educación acerca de ciertos fenómenos, que incluyen atribuciones de relaciones causales entre esos fenómenos. Utilice dicha metodología 
porque los significados son importantes, determinan comportamientos vividos en la sociedad actual y la comprensión de estos nos da la posibilidad de anticiparnos.

Plantear el problema relevante de la responsabilidad civil en las prácticas del profesor en el patio escolar, significa problematizar el mismo como relevante siguiendo con una metodología adecuada, para construir conocimiento o para transformar el contexto actual de la educación física.

\section{Capítulo V}

\section{1. "Análisis"}


En el capítulo anterior abordamos las obligaciones profesionales como la función del docente en la órbita jurídica, ahora en este capítulo el análisis, algunos fragmentos de algunas entrevistas, consideraciones y cuadro de datos.

\section{2. "Fragmentos de Entrevistas"}

Muchos testimonios gracias a las entrevistas pudieron enriquecer la investigación como los relatos de profesores de educación física de trayectoria reconocida o que comienzan recientemente el largo camino de la docencia del sistema en las escuelas. Los cuadros de sistematización, clasificación y organización de los insumos conseguidos en los encuentros con los informantes fueron variados y enriquecedores.

Los sujetos que ampliaron las ideas en todo momento que fueron entrevistados permitieron ir recolectando datos sumamente importantes para el trabajo. Profesionales de reconocida trayectoria en todo momento pudieron ser entrevistados como también docentes con no tanta experiencia como trabajadores en el patio escolar.

La investigación sobre la responsabilidad civil en el patio escolar intenta describir las prácticas corporales de los profesores de educación física en un recorrido por las mismas en la infraestructura que la dirección general de escuelas que debería estar garantizada en las clases de los profesores y en la recorrida de la producción de los relatos permitieron incorporar conocimientos interesantes del estado actual de la educación física escolar.

Con toda la información recogida, en el trabajo de campo, se analizaron datos buscando respuestas a la pregunta inicial. Se trabajó con categorías, diagramadas en el plano conceptual, desde el marco teórico para llegar a un estudio concreto. Palabras claves articuladas en relación al problema de investigación, pudiendo resumir lo siguiente:

- Analizar el artículo 1.117 del código civil, es una tarea pendiente a la vista de las entrevistas en profundidad en el contexto actual. 
- Las obligaciones de seguridad del estado es notoria el no cumplimiento a la luz de las respuestas.

- Se descubrieron contradicciones y hallaron elementos de actualidad que ayudaron a ver que la realidad va muy delante de la normativa legal actual.

- De acuerdo a las explicaciones de los profesionales y actualización de datos, permitieron desnudar falencias.

El conjunto sistemático de conocimientos culturales, creencias y actitudes con respecto al tema en particular permitió determinar una guía para las entrevistas como recolección de datos basada en la utilización de modo flexible de la misma. Las mismas variaron de acuerdo al criterio del entrevistador.

La guía como lista escrita con preguntas que debieron ser cubiertas en determinado orden, manteniendo en todo momento la decisión sobre cómo seguir dicha guía, funcionando como un conjunto de instrucciones claras. Un plan que figuraba en las ideas, pero que también se caracterizó por el ejercicio de un control mínimo sobre las respuestas del informante.

La idea fue en todo momento en cada una de las entrevistas que los informantes se abran, se sientan cómodos y se expresen en sus propios términos. Paso a Paso fui obteniendo datos cualitativos confiables y comparables construyendo la guía de entrevista claramente articulada. Preguntas de interés sobre la problemática fueron determinantes con los informantes claves que determinó un proceso con buenas entrevistas. Permitió con algunos de ellos establecer una cierta confianza y por razones determinantes lograr contactarme con un buen conocedor de ese problema.

La recolección de datos en donde la investigación se desarrolló como un diálogo en el cuál el énfasis estuvo en construir con el informante. Las preguntas en todo momento fueron abiertas pudiendo utilizar la guía de preguntas pero no con la obligación de seguirlas en orden determinado. Explore nuevos aspectos relacionados con el informante a medida que siguió la entrevista. La lista de preguntas no fue determinante como deseable de cubrir. 
Retome informaciones sugeridas en encuentros previos, lo que me posibilitó adquirir nuevos conocimientos y datos. Los aspectos más sensibles pudieron ser explorados en el contexto con un final abierto con actitudes relevadas teniendo la posibilidad de identificar el comportamiento real.

El abordaje a la problemática tiene como objeto encauzar en forma dinámica a la responsabilidad civil que le compete al profesor dentro y fuera del patio escolar.

Con las entrevistas no comienza y finaliza la problemática, sino que se pudo observar en las clases desde el ámbito de enseñanza, que los docentes en general tienen la "sensación" de no estar suficientemente protegidos respecto de las consecuencias que se derivan de los daños que se pudieran ocasionar en la actividad escolar. Las prácticas lo demuestran como sus planificaciones con los mapas de riesgo en los más prevenidos.

En la exposición del problema los profesores transmitieron su preocupación, el armado del marco teórico con las normativas y las leyes para transitar la problemática están para cumplirlos, en cuánto a la conclusión del recorrido final del trabajo realizado integran los saberes de actualidad del profesional al frente del patio, como también de supervisores y abogados.

La búsqueda de lo no conocido o algo que podría estar tapado me sugiere de la elección en las entrevistas a los abogados y a los actores del patio escolar. Buscar la verdad es ir en busca de las respuestas a múltiples interrogantes jurídicos sin perder de vista sus vacíos legales.

El tema elegido en la investigación obliga a pensar las múltiples acciones que desarrolla el profesional en el patio y la responsabilidad civil que quiero investigar muestra las problemáticas que la cruzan y la atraviesan produciendo inconvenientes.

La preocupación de quien garantiza el cumplimiento de las normas en el patio, el derecho a la participación de todos en condiciones materiales dignas, valorar la inclusión de la problemática de espacios y quién garantiza la calidad e igualdad de aprendizajes en lugares seguros y dignos, son los interrogantes claves en las preguntas a los profesionales que manifiestan estar preocupados ya no en sus clases sino en cada accionar futuro. 
Las preguntas formuladas con antelación y el camino a transitar en la escuela detallando el estado actual de los patios escolares muestran una realidad actual del sistema.

La viabilidad del proyecto como los ajustes en la investigación previas a las entrevistas permitieron recortar preguntas reiterativas ya que los tiempos con los que se efectuó el trabajo, como el acceso a los lugares y los recursos humanos / materiales fueron garantizando la relevancia del tema en la educación física.

El tiempo cronológico fue aprovechado en etapas con una necesaria planificación con su corrección con aportes de profesionales involucrados en la temática produciendo insumos. Los aportes en explicaciones, en las descripciones, en las normativas nos fueron dando novedosos conocimientos al trabajo.

El panorama de la responsabilidad civil en el patio escolar como problema insta a investigarlo, numerosos conceptos producen sospechas importantes con motivos alentadores para ir trabajando el problema. La biblioteca, los textos, los autores, internet muy valioso para poder conocer donde estamos parados con la problemática legal.

Ante las entrevistas los profesionales se preguntaban lo siguiente:

¿Qué cosas son importantes saber de la responsabilidad civil que no se conocemos, para no tener que lamentar más daños?

¿En que nos perjudica la responsabilidad civil?

Recortar y localizar el eje fundamental de los problemas legales en el patio escenario de prácticas del profesor nos invita a reflexionar también sobre las condiciones actuales que garantiza el estado, en este caso la dirección general de cultura y educación de la provincia de buenos aires.

Si cada acción es sostenida por códigos legales puede poner en aprietos a las normativas actuales. Casos jurisprudenciales han abierto paso a parcelas del derecho aún no transitadas que se descubren en hechos concretos. 
En el patio escolar los profesores dicen que garantizar el derecho de los alumnos a tener escuelas en condiciones materiales dignas, valorar la inclusión de la problemática de espacios y equipamientos para una educación física olvidada en el sistema sería fundamental.

También la importancia del derecho a la participación de todos, en la nueva ley hay cuestiones fundamentales que deben ser explicitadas y que impactan en la formación de niños, adolescentes, jóvenes y adultos. Para ello hacen falta más recursos y espacios de trabajo adecuados al contexto.

La calidad e igualdad de aprendizajes en lugares seguros y dignos por lo que es necesario explicitar puntualmente los diagnósticos en los distintos niveles y modalidades del sistema donde el contexto de la necesidad.

Redefinir a la educación como una política de estado que planifique las inversiones, las modificaciones y las innovaciones que seamos capaces de imaginar. Caso en que son señalados como estar frente a un claro supuesto de responsabilidad del estado nos muestran que quedan omisiones de control y vigilancia estatal.

El tema responsabilidad civil encierra muchos interrogantes que con las entrevistas pudieron desentrañar lo desconocido en el escenario de prácticas diversas. Quisiera entender, al ingresar en el campo y al salir en los lugares de trabajo de las múltiples preguntas que nos hacemos los profesionales que aún no tienen respuestas. Entender las palabras claves y sus articulaciones con el patio nos va a dar la posibilidad de encontrar líneas de pensamiento, debates, problemáticas, etc.

La responsabilidad civil es el problema a investigar en el patio, partimos de hechos públicos conocidos y preocupantes que aún no tienen respuesta. El análisis y las indagaciones preliminares sobre prácticas que llegaron al daño muestran que aún no están resuelto ni tienen respuestas los distintos interrogantes

En las entrevistas a abogados sobre la responsabilidad civil en las prácticas profesionales de educación física destaco la predisposición de los mismos. El sentido de la vida social se expresa particularmente a través de los discursos que emergen constantemente con el problema en la vida diaria del patio escolar, de manera informal por comentarios, anécdotas y conversaciones. 
Las entrevistas fueron la estrategia para hacer que los abogados como los profesores hablen sobre lo que saben, piensan y creen, en una situación en la cual uno obtiene información sobre lo interrogado. Los hechos, sentimientos, opiniones, emociones, normas o accionar de prácticas encontraron distintas reflexiones, en la cual se obtienen los enunciados y manifestaciones diversas.

Uno de ellos manifiesta que la escuela hace como si enseña, los chicos hacen como que aprenden, los docentes como que enseñamos. La responsabilidad civil son las acciones que los docentes pueden dejar de hacer que impactan sobre la posibilidad de que un alumno no se accidente en la institución mientras juega en el patio o practica algún deporte, entre otros aspectos.

Los docentes están preocupados y superados por el entorno que rodea a las escuelas en cuanto a los márgenes de violencia, de inseguridad y a los conflictos sociales. Las entrevistas sirvieron para obtener muchos datos que dieron acceso a los hechos, hablando del patio escolar las respuestas de los informantes cobraron sentido por su correspondencia con la realidad práctica. Su validez radica en la obtención de abundantes información verificable.

Realidades que construimos con el entrevistado en los encuentros, preguntas abiertas permitieron captar la perspectiva de los actores en las grabaciones. Preguntas relevantes con respuestas amplias permitieron descubrir lo relevante de lo secundario, proceso en el que se puso en juego una relación que las partes. El inicio, desarrollo y el cierre de cada una pudo afirmar que se realizaron en distintos lugares, algunas con concertación previa otras sin la misma y con una duración estipulada.

Los discursos que emergen constantemente de los patios escolares, reuniones de departamentos, de la vida cotidiana, de manera informal en los comentarios nos dice a las claras que las normas no se tienen en cuenta por desconocimiento, por usos y costumbres de prácticas que se reproducen.

Los maestros o profesores rurales, tienen un problema ante un accidente, cuando la norma dice que si un alumno se accidenta no hay que trasladarlo en el auto del docente pero el sentido común es claro que si está en peligro la vida del alumno, si hay que trasladarlo. Este tipo de cosas son las que complican al sistema educativo en lugar de darle tranquilidad. 
Algunas preguntas intentan develar algunas incógnitas:

La responsabilidad civil a la luz de las situaciones que cotidianamente impactan en las prácticas del profesor, en una cuestión frente a la cual ya no es suficiente la sola referencia a la normativa reglamentaria vigente.

¿Qué opinión tiene al respecto?

Es verdad del impacto en el sistema, sobre todo cuando se vivencian accidentes en el patio de la escuela y que son de mucha gravedad. La realidad nos indica que el docente o profesor de educación física no puede estar ajeno al conocimiento de su responsabilidad, para ello debe contar con saberes mínimos acerca de la normativa vigente, la doctrina y la jurisprudencia.

¿Los profesores en las prácticas deberían contar con las herramientas necesarias para poder disminuir los riesgos en el patio y prevenir los posibles accidentes?

Por supuesto, no contar con dichas herramientas demuestra la precariedad en la preparación del profesor de educación física. Sin lugar a dudas y se puede enumerar una cantidad de elementos, en la parte de infraestructura y de índole legal que haría mejorar la prevención. Pueden ser pisos, paredes, todo en buenas condiciones, colchonetas en las jirafas de básquetbol, etc. En la parte legal tener en cuenta las autorizaciones de los padres, seguro, revisaciones médicas, etc.

¿Es importante el aporte de charlas, conferencias, debates sobre el problema?

Deberían existir conferencias a cargo de especialistas con carácter periódico para seguir el avance de la legislación, la jurisprudencia y la doctrina. Si y en forma intensa, 2 o 3 veces al año, en las escuelas. Funcionaría mejor la prevención del posible accidente deportivo. Que se pueda dar desde la misma forma que se realiza en la medicina, en donde en esa área también se lucha muy poco a diferencia de los países más desarrollados, que invierten mucho más dinero en estos temas. 
¿Los directivos de las escuelas están presionados con respecto a estos temas de la responsabilidad civil para los torneos, encuentros masivos, salidas y trabajos en piletas?

Probablemente aquellos que hayan tenido alguna dificultad, pero no hay que dejar de hacer, sino hacer mejor. Si no están presionados mejor en buena hora y a disfrutar de la actividad. Si estamos presionados y a veces nos tomamos permisos sociales que pueden ser contraproducentes para los temas legales si existe el daño.

¿Cómo podríamos mejorar la responsabilidad civil en el patio?

Educando, enseñando a los profesores, a los padres, a los alumnos y al personal no docente que todos sepan qué hacer ante determinadas circunstancias y sobre todo que se planifique adecuadamente. Con mucha prevención, desde todos los puntos de vista.

En los últimos años se han dejado de hacer un sin número de prácticas en los patios y en las salidas con alumnos a cargo.

¿Por qué?

Si se dejaron de hacer encuentros y torneos como los traslados con alumnos además de campamentos. Si estamos bien organizados, contamos con seguro, la conducción es eficiente no tienen por qué dejar de realizar actividad. Algunos aspectos que hacen a la diagramación de los distintos deportes que se practican allí. Y por supuesto incluido a la responsabilidad civil que deben ejercer los profesores a cargo, cumpliendo la tarea en todo momento y nunca dejar a un grupo desatendido.

Los institutos nacionales o provinciales de educación física de nuestro país

¿Deberían formar a los alumnos con más preparación en cuantos a los problemas jurídicos?

La materia de legislación donde se toca la responsabilidad civil debería ser obligatoria en todos los institutos de enseñanza docente. Si, lo que ocurre con esta gran temática que muchos institutos de formación docente, aún preferirían no tocar el tema. Pero ahora está cambiando bastante la mentalidad de los que tienen que ejercer la 
autoridad educativa de los Institutos y le están dando más importancia. Dada la gran cantidad de demandas judiciales que hubo en los últimos quince años y que han sido tapa de varios diarios del país.

¿Deberían ser más prudentes los directivos de las escuelas?

Ser prudentes, pero no paralizarse, hacer las cosas mejor, tener autoridad moral, saber exigirse para exigir. Por supuesto siempre hay que ser cauteloso, y adaptarse totalmente a las instituciones que posee la escuela. No cometer ningún error. Por ejemplo no practicar rugby si solamente tenemos un playón y no una cancha de rugby. Esas reglas de oro, siempre hay que respetarlas.

Nos lleva a realizar un análisis, que es indispensable que cada profesional de educación física verifique las medidas de seguridad operantes para evitar las lesiones en las práctica de las actividades físicas - deportivas, antes de empezar la actividad, las que demandarán en primer lugar, la presencia activa y alerta del profesor de educación física, en todo momento y realizar un análisis de los posibles riesgos, antes de empezar con la actividad, para después poder atenuar el accidente deportivo que pueda ocurrir, y así buscar los medios eficaces para evitar que esos riesgos se transformen en daños físicos, es mejor perder el tiempo en ese análisis, y no analizar después al accidente cuando ya es tarde.

El tema es muy interesante y coincido en que hay mucha preocupación por el tema. Lo esencial es basarse en el código civil, artículos 1109, 1113, 1117. En caso a quién afrontaría el pago de los daños sufridos por el alumno si se nos lastima en el patio mientras se encuentra bajo el control del profesor, la respuesta es que depende de las circunstancias del caso.

Porque puede existir culpas concurrentes frente al mismo hecho. Por ejemplo si el alumno se lastima porque el hecho del profesor le causó daño (sea por acción u omisión en los cuidados) es su culpa. Si el daño es causado por el uso de las instalaciones deficientes (vidrios, caída del techo, etc.) la culpa es de la Institución. En conclusión pueden existir conjuntamente diversas responsabilidades derivadas de un hecho. 
Muchas preguntas y algunas respuestas sobre las prácticas del profesor de educación física en el patio de la escuela.

¿Quién es más responsable por todo esto que está aconteciendo en los patios olvidados, será la institución, el profesor, el estado, el seguro, todos?

En las prácticas del profesor como eje transversal que cruzan las mismas el cuidado del cuerpo como también todas las acciones a que dieran lugar el proyecto educativo institucional. El cuidado del cuerpo considerado desde la propia disciplina adquiere una trascendencia más allá de lo meramente físico.

A veces nos preguntamos si es un tema que tanto preocupa a los profesores

¿Porque se trata generalmente frente al hecho consumado?

El problema que abordamos contrasta con lo que apreciamos en las prácticas, hay mucha incertidumbre respecto del futuro. Del tema no se habla previamente pero cuándo está el hecho consumado, todos no tenemos responsabilidad ante el daño.

Los fines y objetivos de la política educativa nacional garantizan una educación integral que desarrolle todas las dimensiones de la persona y habilite tanto para el desempeño social y laboral, como para el acceso a estudios superiores. Garantiza en el ámbito educativo, el respeto a los derechos de los/as niños/as y adolescentes establecidos, cómo también garantiza a todos/as el acceso y las condiciones de permanencia y el egreso de los diferentes niveles del sistema educativo, asegurando la gratuidad de los servicios de gestión estatal, en todos los niveles y modalidades.

Según la ley brindará una formación corporal, motriz y deportiva que favorezca el desarrollo armónico de todos/as los/as educandos/as y su inserción activa en la sociedad.

\section{Entrevista a docente de educación física}

Destaco la entrevista de una profesional que quiso dar su aporte a esta investigación sabiendo de dicho trabajo y la misma aporto su experiencia como profesional para acrecentar datos de importancia. 
Relato de experiencia como parte de proyecto de escuelas en verano, que sucedió en un distrito de la Provincia de Buenos Aires. Comentario de una reunión de escuelas en verano en acto público que involucraba a más de 2000 chicos del distrito en donde estaban publicadas las escuelas y por orden del listado podías elegir la escuela con inclusión del comedor para chicos, pileta del parque municipal (5 o 6 escuelas) implicando traslado de los chicos al lugar, la comida se le lleva al lugar y en esa reunión se elegía una escuela con muy poco profesores que pensaban en los problemas legales.

La responsabilidad que tomamos de la cual uno es responsable con la guarda del menor, lo pensé antes de elegir los grupos y pregunté a qué pileta tenía que ir. Tengo 14 años de trabajo y varias experiencias en estas escuelas de verano.

No todas las piletas son iguales, manejan algunas escuelas una matrícula de 100 alumnos, otras mucho más y quería ver cuantos profesores habían solicitado esas escuelas por la que elegí una. En esa misma reunión se manejaron las siguientes consignas: Profesores podían cambiar la sede el lugar que eligieron, un cuestionamiento es que un profesor esta cargo de una escuelas y es responsable de esa escuela te desempeñas en esa no en otra, luego de ese acto público se realizaron otras reuniones en las que se dieron las directivas generales, podías solicitar otro lugar, cambiar de función ir de guardavidas a otra sede, cambios de niveles para hacer ágil en lo pedagógico, me lleva a reflexionar los cambios que no llegas a conocer ni el $25 \%$ de los alumnos de cada grupo.

Cada día esto mostraba un nivel de peligrosidad alarmante pero igualmente no había comentarios, cada uno llegaba al lugar se hacía algo recreativo fuera del agua, comenzaban las clases de natación, el ingreso era ordenado, y organizado por escuela, hasta que se organizaban en el borde la pileta por cada profesor, los grupos por nivel, se perdían el referente que tenían con su profesor, ya que los niños rotaban, algo que me resulto peligroso, de hecho en el lugar que yo trabaje cambiaron de modalidad, en contraposición con algunas directivas algunos profesores empezamos a manejarnos individualmente.

Cortamos este convenio y la escuela comenzó a trabajar con sus propios alumnos, solos fuera del agua. Para criticar el tema de la maestra que te acompaña y que no está preparada para cuidar en la pileta, tres con 80 o 100 pocos, entraban con grupos de 15 no tantos chicos con un profesor, menos carga horaria en la semana pero más 
seguridad, que no se cuestionó en lo absoluto, lo que me deja margen para decir que si no reflexionamos nosotros, todo lo que esto implica que somos los profesores a cargo de estos chicos, no pueden reflexionarlo nadie, porque los padres te encargan a sus hijos como sus hijos, y que nuestra tarea implica mucho más que enseñarles a nadar.

El 10 de Enero cuándo comienza todo fallece un chico de muerte por inmersión en otra sede, realmente me paralizo y bueno a partir de esto, los pasos que siguieron a partir del fallecimiento fueron sumarios, la cosa toma otro carisma y todo lo que siguió después. Tome conocimiento por afuera no me dieron ganas de indagar nada, pero me dejo con un gran signo de interrogación, en cuanto a que estamos más de 20 profesores trabajando en esto, a partir de este fallecimiento me sigo preguntando, si se podíamos haber cambiado las cosas, si teníamos desconocimiento, si teníamos conocimiento igualmente iríamos a trabajar.

Si a nadie se le ocurrió cambiar las cosas, y el ejemplo decidimos hacerlo de otra manera, no fue por ser los mejores, también puede mirarse esto en términos de un accidente, que le puede pasar a cualquiera que este ocupando una pileta., mi pregunta es lo que ¿agotamos los directores, inspectores, profesores, coordinadores, maestros, todas las posibilidades de búsquedas para saber realmente si estábamos pensando en que algo podía suceder?.

Me lo cuestioné y lo modifique, el 10 de enero que ocurre esto, se suspendieron las clases 10 días de pileta, de la causa legal no tome conocimiento cual fue el trayecto, siguió lo que se estipula en estos casos, me refiero a que se siguió con las clases de pileta, luego de la suspensión, después, no hubo ningún cambio, las cosas continuaron igual, los profesores que estaban como Guardavidas renunciaron pero llegaron otros.

Solamente una muerte es lo que produjo o no lo quiero guardar como una opinión personal con un gran dolor. Transcurre todo el año, se proyecta nuevamente la escuela de verano, siguiente voy al acto público porque necesito trabajar en verano y me gusta, mi primera experiencia en esto fue en el año 1987, donde se realizó una prueba integral me entusiasmo mucho y seguí, el verano siguiente voy y lo voy hacer en otro clima en un contexto de seguridad real, bajo los cambios que implica un fallecimiento, las cosas no pueden seguir iguales, en el acto público teniendo conocimiento hice muchas preguntas, que hacen teniendo conocimiento del estatuto 
del docente, de la responsabilidades que nos atañe y además por una cuestión de información generalizada, para las respuestas que se me daban sean tomadas en cuenta para mis compañeros veo que las cosas no habían cambiado.

Me parece que en ese momento me dio la sensación de que todo estaba igual, no tome ningún cargo y trabaje en algo que estaba fuera del ámbito de la educación física, pero no me pareció para nada exponerme a que esto pueda suceder porque las consecuencias de esto por lo que veo al menos las consecuencias morales las tenían todos los profesores que compartían esa pileta, todos los docentes, la directora, no vi si estaba en la pileta, en algún lugar alejado del parque, entonces quiero recrearte con esto nada más que lo mínimo que podemos hacer es estar informados en las condiciones en que vamos a trabajar, porque tenemos en nuestra manos chicos, la guarda del menor desde que entra en la escuela hasta que se va que no es poco decir.

Tendríamos que revisar las condiciones, porque no solo es que necesitamos el dinero para trabajar y meterle para adelante, sentido común se maneja esto, vas dos horas cobras tanto, y si hace frío no das natación das futbol, voleibol, hándbol que a ellos les gusta, me parece que una muerte es un motivo para indagar, de que me estoy responsabilizando, de que nos estamos responsabilizando. Reflexiones de una profesora con experiencia, $70 \%$ de los profesores no tiene experiencia, se reciben y toman esto.

Lo estoy comentando en un marco de irregularidad previa, yo podía haber ido de Guardavidas sin grupos a cargo en la enseñanza. Creo que tenemos que saberlo si somos designados en un acto público, para actuar en una escuela, desde el momento que me hago cargo de las horas en la escuela soy responsable de los chicos de esa escuela, si yo me cambio de lugar de hecho seré responsable del lugar, pero no creo que teniendo un mínimo de razonamiento diga yo quiero ir de guardavidas a un lugar con 700 chicos, yo no lo hago.

Viendo que los profesores toman cargos que son los que trabajan por primera vez son chicos sin experiencia, formación profesional que no tienen en cuanto al conocimiento de toda esta problemática jurídica. Yo intuí al año siguiente que no había cambiado nada en las asambleas, mis preguntas apuntaban más a abrir ojos y oídos de todos los que estaban en el acto público que a lo que yo quería saber, porque en realidad yo 
intuía que no había cambiado nada, bueno en realidad no cambió nada, se sigue haciendo y este año se va seguir haciendo igual.

Yo no trabajo porque no quiero, no como acto de cobardía sino todo lo contrario me parece una atrocidad cumplir otras funciones asistenciales y yo no cumplir con lo pedagógico con la absoluta responsabilidad que se merece. Me preocupa el no cuestionamiento de directivas, no cuestionarlas, acatarlas, porque tengo un jerárquico que supuestamente lo pensó, entonces me mandan acá, voy acá o tomo esta escuela y si el piso es así o no bien o no, si estamos 400,100,90, o 35 adentro de la pileta o si podemos alterar el orden, decir no yo trabajo con mi grupo y son 15, creo que solamente está en nuestras manos cuestionar este tipo de cosas. Cuando se juega con la vida. Si la responsabilidad atraviesa en forma permanente y acá tenemos un gran tema pedagógico y por otro lado un tema puramente jurídico, no podemos dejar de reconocer que las prácticas en la pileta esta atravesadas de todo esto de lo jurídico.

La experiencia que tengo al trabajar en un pileta climatizada y privada las condiciones son otras, no por eso contrastan una cosa con la otra quiero decir. Experiencia como ámbitos, no por eso desconozco lo que es una pileta, clubes y escuelas de verano, ámbito formal, no formal, privado. El profesor nos movemos en los tres ámbitos, yo trabaje en los tres, no me interesa lo privado o formal, creo cada práctica está atravesada por un cierto grado de responsabilidad sobre la vida después lo que aprenden. No puedo dejar de ver y protestar por cómo está el agua, como son las instalaciones, por si el piso está roto, el criterio es personal de cómo trabajamos.

Esto tiene que cambiar, no tiene que ocurrir, y en un marco de accidente real, que a cualquiera nos puede ocurrir. Critico el no cuestionamiento ante la acción, se hace una propuesta no hay cuestionamiento, se va a la acción directamente, explorar el contexto con cuestionamientos sin temor donde yo voy a estar trabajando con chicos. Eso sí, con respecto sobre los cambios, no todo cierra en la comida y en el aguante del chico de 8 a 12 horas. Parecería entenderse de estos términos porque cuando voz estás adentro de estos lugares, todo parecería cerrar que están bien porque desayunan, almuerzan y están en un lugar de 8 a 12.

Creo que podríamos darnos otros gustos como compartir verdaderamente prácticas de la educación física. En el sentido los profesores podrían ofrecer propuestas, las directoras podrían solicitar propuestas de parte de los profesores, el profesor se vería comprometido, las directoras podrían evaluar el desempeño a conciencia, no todos 
somos iguales, profesores con verdaderos criterios de cuidados en sus prácticas es lo importante. Darle el verdadero sentido al profesor, no en un lugar cerrado conteniendo al alumno comiendo o merendando, primeramente depende de cada uno de nosotros, estas políticas a lo mejor tienen conocimiento, pero de la responsabilidad es nuestra, nadie tiene prohibido elevar notas, vía jerárquica, no la desvinculación absoluta, toma el cargo, da clases y se retira.

Yo no estaba en condiciones ni de tiempo, cambiar es posible, los inspectores están abiertos a recibir en algunos niveles, a cambiar, los profesores somos los mismos, los padres tienen como un permiso para cuestionar más al docente, alguna tienen razón otras no, obvian jerarquías, acceso a las cargos jerárquicos, más al asecho en estas cosas. No puede estar ausente el cuestionamiento de estos temas, de parte de los profesores, no me parece mal que se acerquen los padres en los establecimientos por las vías de comunicación, el rol del director como mediador manejado éticamente me parece bien.

El padre es un informante clave para el docente, a veces viene mal son confusas, pero es determinante respecto el padre - docente. Las cosas se pierden en algún agujero negro de la no trascendencia, llegan hasta el inspector, jefe, etc. Lo que pienso es que el primer paso lo tiene el docente, pero como decimos no me va a pasar nada pero por desconocimiento me pasan las cosas, a veces por ignorancia, e incluso el estatuto dice ver articulo tal, falta bastante tiempo para esto, hasta que todos digamos, en el patio tengo arena, lo solucionemos en cada contexto, asumamos que vengan conflicto, hasta que no podemos hacer nada, por conflictos permanentes, desfile permanente de padres, la palabra del profesor es el primero en decir yo dicto clases de educación física, el director tiene la palabra, el no compromiso lleva dientes, lleva vidas, no es un tema menor, responsabilizarse, cuestionar de las cosas que no están bien, tampoco es así buscarle la vuelta, no compromiso, si hay baches en la legislación somos los profesores en cambiar y reflexionar. El tema es denunciar una irregularidad al respecto.

\section{Entrevista a docente}

Mi agradecimiento ante esta entrevista, posterior a un hecho de público conocimiento y que tuvo trascendencia nacional. 
El tema de responsabilidad civil es candente e incluso por el hecho pasado de público conocimiento. Nos sentimos ignorantes por el hecho, responsabilidad sobre ellos en un determinado horario, sensibilizado el tema, tenemos miedos, no tenemos asesoramiento y demandas avasallantes. El hecho a suscitado preguntas entre nosotros, hasta donde somos responsables, donde paso no había ningún docente en el lugar. Estamos huérfanos, había que intervenir o no, teníamos que estar o no, en lo que a responsabilidad se refiere. Ante un hecho de estas características, actúa uno por instinto o nos planteamos otras cosas. Somos culpables o no, el preceptor tiene a cargo tres cursos, estaba tomando lista en la sala de al lado, entonces hasta donde somos responsables.

Que pretende la sociedad del docente, como no actuario o no, el docente es mano santa, tiene que hacer todo, tiene que dar contenidos, como no se dieron, en esta ciudad es todo un tema el hecho. La docencia está en crisis, uno se siente responsable o culpable de la forma en que pasó. En mi planificación tengo un mapa de riesgo, deposité una pequeña bomba a mi inspectora de lo que yo veía del problema de la responsabilidad civil, seguridad, vidrios rotos, accidentes todos los días, uno da los primeros pasos y asesoro a los docentes. Tramitaciones en la que uno no está acostumbrado sumado a los problemas por el hecho, ahora estoy más al salto por todo lo que paso, pasa algo lleno las planillas, me contacto con los padres, ahora tomamos más conciencia.

Una época muy sensible para nosotros, tema que planteamos los docentes que tenemos que saber, que tenemos que hacer, nos limita y cada vez más atados. El conocer y el informarnos nos limita. Porque uno va tomando conciencia de un montón de cosas que antes no las tomaba. Estamos cruzados por el hecho, el inspector nos plantea, por favor tener en cuenta todo, pongan especial atención por lo que hacen, utiliza lo que no pueda ocasionar algún problema. Es complicado el tema, manejar el tema de prever es difícil, nos dicen que utilicemos estrategias, pero a veces las mismas nos indican que tenemos que utilizar todo el espacio que no tenemos.

A veces en hándbol utilizamos dos arcos no uno, el espacio es $10 \times 10$, con 20 chicos que practican ese deporte y es difícil. Es complicada la situación, hemos cortado las caminatas, las salidas, nos hemos inmovilizados, ahora a la profesora le da miedo. Pueden ser que los conforme a los chicos una situación de la que hoy no pueden afrontar psicológicamente y me puede pasar cualquier cosa, que hago, me quedo en la escuela. No salgo, si lo hago por fuera de los horarios, pero nos reunimos y no lo 
hacemos, lo charlamos, toda la ciudad se ha visto inmovilizada, por miedo. No se trata abiertamente el tema, si los directivos manifiestan que la responsabilidad tenemos y que no es fácil.

Los directivos nos transmiten la responsabilidad que tenemos, en estos temas, pero no se habla y no se buscan las razones. No entramos en los detalles, si es por las cargas de horas, por estar frente al cargo, no usamos la palabra responsabilidad civil. Podríamos abrir el tema, en definitiva dependemos de cada uno en un lugar alejado, donde la escuela se crea sin porteros, contra eso no se puede decir nada, hubiera sido mejor crearlo con un gimnasio mejor.

El lugar alternativo que utilizamos fue una demora en el pago del alquiler, tardaron un año en pagar el mismo, desde hace un año estamos funcionando con vidrios rotos, el alambre caído, con pozos en el gimnasio, demoras en infraestructura ya que los trámites no salían.

La carrera que tenemos es de docentes, no de directivos, ni de gestión por lo que hay muchas cosas a lo que no estamos informados, ni formados, se logra a través de la experiencia, por lo que cuando te pasa recién te das cuenta y no se puede prever. El instituto no nos prepara para la gestión, no lo aprendió, ni prepara para la responsabilidad que implica la misma, entonces cuando uno está en gestión, uno dice es mi responsabilidad, es mi problema, si pasa algo es culpa mía, el camino es de la experiencia, cosa que no creo que tenga que ser así, no es lo mejor, la experiencia ayuda pero no es todo. Lo mismo pasó para el concurso de titulares, un examen teórico y estar en un servicio no es lo mismo.

En este momento en mi escuela es de primer orden de prioridades la responsabilidad civil, estamos todos pendientes que no nos pase nada, que los canales estén bien aceitados para llama al médico, si tengo una ambulancia, en las condiciones que estaba la escuela, esto es prioridad, porque paso un accidente a las dos semanas del problema, en un turno descubierto y me encuentro con la ambulancia y con una alumna con el cuello ortopédico y una camilla, no tenía secretario, decir el estado de shock en que me encontraba no te lo puedo descifrar.

No quiero que pase nada, que este coordinado todo, que el médico esté con el celular prendido todo el día, no tengo teléfono en el servicio, cosa que me compre un celular, hay un montón de cosas que uno tiene que tener como prioridad. La salud del alumno 
es prioritaria, si un alumno tiene una lesión se corta la clase, es la prioridad atenderlo, se llama al hospital, a la ambulancia.

Uno no está tranquilo hasta que termina la clase, uno antes lo miraba de otra manera, yo cerraba las caminatas con 120 chicos con dos profesores y caminaba una vuelta por el pueblo y decía que no me pasaba nada, no tenía asesoramiento pero cuando paso, deje anotado en el turno por escrito que es lo que tenía que hacer. Ningún directivo de media me dijo algo con las caminatas y presenta el proyecto por escrito y listo, no mira la cantidad de alumnos en ese momento, luego del hecho ocurrido cambió.

La responsabilidad aún no esclarecida de los hechos relatados en las entrevistas por daños causados por los alumnos como sufridos por el mismo aún tiene la incertidumbre de los profesores impactados por los hechos. Analizar el artículo del código civil 1.117 nos insta a leer y repensar otros obligados a la problemática. Existen contradicciones y las explicaciones de los profesionales nos marcan la problemática a la luz de las situaciones.

\section{Consideraciones}

Los docentes tienen derechos y obligaciones, sin perjuicio de los que establezcan las negociaciones colectivas y la legislación laboral general y específica. Nos habla de que las tareas del profesional desarrollarán sus tareas en condiciones dignas de seguridad e higiene. Tendrá beneficios de la seguridad social, jubilación, seguros y obra social. A proteger y garantizar los derechos de los/as niños/as y adolescentes que se encuentren bajo su responsabilidad, en concordancia con lo dispuesto en la Ley Número 26.061.

El estado debe garantizar las condiciones materiales y culturales para que todos/as los/as alumnos/as logren aprendizajes comunes de buena calidad, independientemente de su origen social, radicación geográfica, género o identidad cultural.

La institución educativa es la unidad pedagógica del sistema responsable de los procesos de enseñanza - aprendizaje destinado al logro de los objetivos establecidos por esta ley. 
Pasando a la ley provincial respecto a la Infraestructura escolar en su artículo 115 dice que la Dirección General de Cultura y Educación ${ }^{22}$ tendrá a su cargo la Infraestructura escolar a través de un organismo técnico - administrativo específico a fin de garantizar la construcción y habitabilidad de los espacios necesarios para el desarrollo de la enseñanza. Para el cumplimiento de sus incumbencias, este organismo implementará un sistema de supervisión de la infraestructura escolar en el territorio, designando para ello Inspectores Regionales, los que asignan la colaboración, participación y articulación con las funciones específicas que tienen los consejos escolares en cada Distrito.

En el artículo $116^{23}$ de la misma ley dice que es función de la Dirección General de Cultura y Educación garantizar un hábitat adecuado en los espacios destinados a la enseñanza teniendo en cuenta necesidades y características socio - culturales y ambientales de la comunidad. En este sentido es competencia del organismo desarrollar y lo coordinar los aspectos concernientes a la planificación, la elaboración de normativa técnica y a la proyección, ejecución y fiscalización de obras de infraestructura escolar sean estas efectuadas por administración o por terceros. Coordinando también acciones para proveer el equipamiento escolar adecuado garantizando el respecto a la normativa vigente respecto a la seguridad e higiene.

En el artículo 117 la Dirección General de Cultura y Educación, a través del organismo mencionado tendrá a cargo la coordinación de las políticas edilicias en función de planificación y control del mantenimiento preventivo y correctivo de la infraestructura escolar y velará junto al resto de las áreas por una utilización óptima y sustentable de la misma. A tales efectos, se consideraran las propuestas de los organismos colegiados locales. Deberán tener en cuenta la incorporación, al diseño y la gestión del espacio físico educativo, las limitaciones climáticas, los requerimientos energéticos y las condiciones resultantes de situaciones ambientales globales y locales emergentes del cambio climático y la transformación del patrón energético. Deberán incorporarse conceptos tales como: entorno saludable, en la dimensión mediata, inmediata y social, diseño ambiental y bioclimática, tecnologías de conservación y de sistemas pasivos de acondicionamiento, usos sustentables de la energía, materiales y equipamiento sin impacto en la salud de la comunidad educativa.

\footnotetext{
${ }^{22}$ Ley Provincial de Educación $N^{\circ}$ 13.688. Capítulo IV. Las Infraestructura Escolar.

${ }^{23}$ Ley de Educación Provincial 13.688. Capítulo IV. La Infraestructura Escolar.
} 
Posteriormente los consejos escolares ${ }^{24}$ poseen las siguientes facultades, en el ámbito del distrito.

a) Gestionan la provisión de muebles y útiles y demás elementos de equipamiento escolar y proceder a su distribución.

b) Implementar en el distrito la ejecución de actos administrativos emanados de la Dirección General de Cultura y Educación.

c) Administrar los recursos que por cualquier concepto la asigne bajo su responsabilidad la Dirección General de Cultura y Educación.

d) Realizar censo de bienes del estado.

e) Participan de las reuniones de la unión educativa de gestión distrital, junto a los representantes municipales, de los gremios, inspectora jefe distrital, Secretaría de Inspección, entre otros para priorizar las construcciones edilicias del distrito.

Los inspectores del área, en este caso de la educación física llevan a las reuniones las prioridades de posibles construcciones. El largo camino para recorrer la vía administrativa es también un poco complicado para su aprobación, por ejemplo de un patio para la educación física, gimnasio, o más aún una pileta de natación. Las políticas de los políticos de turno tienen mucho que ver para sumarse al proyecto $o$ para quizás no dar la prioridad.

Las Instituciones que tienen problemas en cuanto a la infraestructura edilicia de patios para la educación son muchos, si tenemos un diagnóstico de datos relevantes del distrito es el punto de partida para proyectar un trabajo en conjunto si hablamos de educación física y deportes.

Los aspectos presupuestarios hay que sumarles los aspectos operativos, históricos, culturales, sociales. El lugar más público de la escuela pública tendrá el escenario digno para el cumplimiento de proyectos de educación física y del deporte del distrito.

Para construir la educación que todos quieren es importante considerar el capital cultural, social, económico y el simbólico de cada uno que al trabajar en red atiende a

\footnotetext{
${ }^{24}$ Ley de Educación Provincial 13.688. Capítulo IX. Los Consejos Escolares.
} 
la diversidad de la población. Dentro de la crisis de la educación actual los patios donde los profesores dan clases no son la excepción, enfrenta el problema también de la arquitectura escolar y la pérdida cualitativa de espacios.

El patio espacio esencial de los niños pretende dar una respuesta a la búsqueda de soluciones. Las instituciones como realidades sociales abiertas al entorno está obligada a considerar el marco legal y jurídico que la ampara, la estructura administrativa en que se encuadra como las posibilidades que le proporciona el entorno, los valores y actitudes que la sociedad demanda y las características.

Todo proyecto tiene datos del contexto, capacidad de generar ideas, capacidad de observación, hasta donde puedo construir, capacidad de anticiparnos, sabiendo que cada escuela está atravesada por discursos institucionales. Aparecen también las disputas en los espacios escolares, planear o planificar o elaborar proyectos es conocer la escuela, los recursos humanos, los pasos, las faltas de los docentes, etc.

\section{El trabajo de los datos producidos}

El analizar los discursos de los profesionales invita a pensar la falta de previsión, de anticipación a los hechos en distintas circunstancias, tiempo y lugar.

La investigación permitió explorar los distintos impactos en diferentes contextos en épocas de crisis de la educación en la que la educación física no puede desligarse de la educación actual.

El escenario actual de los patios no es el adecuado, lo que permitiría iniciar el debate sobre la real importancia que se le da a la educación física actualmente en lo político y en la política.

El distrito sobre datos de infraestructura escolar y sobre las necesidades reales de tener un patio adecuado indica posibles políticas de inversión aún no satisfechas en la mayoría de los establecimientos. No está la prioridad.

La falencias son muchas, en las entrevistas, en las observaciones, en los organismos estatales aún no hay respuestas concretas, solamente pocos no muchos con esfuerzos de directivos, profesionales u otros logran respuestas luego de años de gestión. 
Luego de las experiencias vividas como profesores en los distintos contextos reflexionan sobre los hechos y posteriormente los cambios no aparecen salvo cuando se preocuparon sobre el regreso al daño y el cambio propuesto como mirada paradigmática.

\section{$\underline{\text { Identificación de los relatos }}$}

Luego de varias entrevistas, algunos conceptos de los relatos que son interesantes a la luz de los hechos en diferentes contextos serían:

- Se piensa en el tema legal después del hecho.

- No todos los contextos son iguales.

- La modalidad cambia, la identidad se va perdiendo.

- Los padres nos encargan a sus hijos lo que implica una gran responsabilidad.

- Ante el hecho, ¿cómo se actúa?

- No cambio nada en mi ciudad con el hecho, todo siguió igual.

- Pensar en las condiciones de infraestructura, reflexión de alguien con conocimiento y experiencia.

- Si reglamentan los lugares de trabajo desapareceríamos los profesores de educación física.

- Preocupados por los no cuestionamientos.

- Las cosas se pierden en un agujero negro.

- La responsabilidad civil es un tema candente.

- La docencia en su totalidad esta en crisis. 
- Estamos cruzados por la responsabilidad civil. No estamos informados ni formados para esta problemática.

El estado actual del patio de educación física en el distrito demanda una inversión importante para ir cambiando la situación, sumados a los edificios escolares de infraestructura.

La responsabilidad civil que le compete al profesional dentro y fuera de la institución escolar, debe formar parte de una política de estado en cuanto a la prevención, seguridad, patio adecuado a las prácticas del profesor y documentos emanados de la Dirección General de Cultura y Educación remitiendo orientaciones para el abordaje de la problemática en cuestión.

Las normativas recibidas en los últimos años no contribuyeron a eliminar los miedos por completo de los peligros de una vez por todas, respecto a los alumnos de que puedan tener acceso a prácticas educativas bajo control de autoridad educativa sin riesgos.

Seguramente contribuye al problema los edificios inadecuados, docentes con bajos salarios con poca identidad en la escuela, poca preocupación del estado por los patios de los profesores de educación física lo que obliga a un replanteo general.

Es muy importante el debido diligenciamiento en la denuncia, toda vez que un alumno sufre un daño en un establecimiento educativo durante el horario escolar, corresponde al establecimiento comitente demostrar su falta de culpa o la observancia de todos los cuidados que corresponde a su deber de vigilancia mientras que el alumno (padres) le basta con acreditar que el perjuicio padecido por el estudiante se produjo dentro de la escuela.

Reflexionar sobre ¿cuál es el ámbito espacial de la responsabilidad?, el propietario del establecimiento responde cuando el alumno sufre un daño hallándose en la escuela, extendiéndose a las salidas programadas por el colegio. Del mismo modo, si el hecho dañoso se origina dentro del establecimiento, pero produce sus efectos fuera de él también responde el propietario. 
La responsabilidad civil surge como consecuencia de los hechos dañosos provocados a terceros o quienes estén bajo su guarda, los asegurados no solo son la dirección general de educación de la provincia de Buenos Aires, sino los dependientes, cuerpo docente, directivos, cooperadores, personal auxiliar entre otros.

Los alcances y las características del riesgo cubierto son importantes considerarlos a la hora de ver quiénes son los responsables en circunstancias, tiempo y lugar. Como también lo que el seguro no cubre.

Numerosas lesiones de alumnos son denunciadas por directivos que sufren en las clases de educación física, incluyendo también la responsabilidad que resulte de actos de los alumnos, pero únicamente mientras se encuentre bajo control de autoridad educativa son cubiertas.

Tener en cuenta los daños materiales a terceros que surjan de operaciones y o actividad docente. Los riesgos en las excursiones o cualquier otro tipo de salida o visita mientras se encuentren bajo control de autoridad. También considerar que comprende toda actividad estrictamente curricular, como actividad planificada deportiva dentro o fuera del establecimiento.

En la carrera de educación física manifiestan que es necesario se profundice sobre la problemática jurídica, en especial la responsabilidad civil y una capacitación jurídica en educación es una tarea pendiente para los profesores de educación física.

Luego de los análisis y evaluaciones de las distintas actividades desempeñadas en la práctica profesional y responsable del servicio educativo desarrollado en tal sentido, se advierte la necesidad de efectuar modificaciones en pautas establecidas en las reglamentaciones de la dirección general de cultura y educación en la modalidad educación física.

Si las actividades son promovidas y organizadas por los distintos establecimientos educativos dependientes de la dirección general de cultura y educación, el garante debe aprobar normativas aplicables a la realización de prácticas de configuraciones de movimiento en los establecimientos educativos, bajo control de autoridad educativo acordes a la realidad actual de los contextos. 
Las circulares técnicas de educación física, es necesario actualizarlas al contexto actual provincial, arbitrar por todos los medios, para que los alumnos tengan la posibilidad de practicar distintos deportes, en ámbitos adecuados con seguridad.

Si propiciamos hábitos de vida saludable que impacten en los alumnos enriqueciendo la construcción de sus proyectos personales o sociales el medio de práctica en donde se desarrollen las propuestas deben considerar pautas estrictas de cumplimiento obligatorio.

Recordemos que para eximirnos de responsabilidad el director o el profesor de educación física deberá demostrar la imposibilidad de impedir el hecho dañoso, la existencia de dicha imposibilidad pese a las potestades que ejerce para vigilar a los alumnos y que observo todos los cuidados que correspondía a su deber.

La educación física actual en todos los niveles deben dar lugar a un profundo debate en incluso de nominación en el cual podría llamarse educación corporal y revisar todos los diseños curriculares en los contextos actuales donde la normativa legal vigente tiene soporte en cada acción.

La responsabilidad principal de la educación es del estado, cómo el marco de la legislación Argentina desde las leyes fundadoras del sistema y la escuela al igual que el patio necesita de inversiones para su mejoramiento en infraestructura definiendo objetivos y metas a mediano y largo plazo, aunque parezcan utopías explica el profesor entrevistado como necesidad indelegable de la dirección general de cultura y educación.

La planificación de las inversiones, modificaciones y las innovaciones que seamos capaces de imaginar no ponerles límites. Revisar los criterios de asignación de recursos educativos no solo en las jurisdicciones sino dentro de ellas y pensar en una política de desarrollo investigativo.

Consideran necesario explicitar puntualmente las necesidades para el desarrollo de la clase de educación física en la escuela en los distintos niveles y modalidades del sistema, como también la escuela rural debe estar en igualdad de condiciones de atención como la escuela de la ciudad es lo que el profesor recién recibido dice. El contexto da la necesidad de acuerdo al nivel y modalidad del sistema. En la práctica concreta en el surgimiento del recorrido de los escritos y en la elaboración para 
transmitir con claridad al lector durante la investigación se pudo observar problemas similares en los contextos rurales y urbanos.

La problemática de la responsabilidad civil en el patio escolar a la luz de las situaciones que cotidianamente impactan en los establecimientos, la sola referencia a la normativa legal vigente ya no es suficiente y necesariamente debe ser actualizada ya que no conviene jugarse del todo por si pasa algo.

Según Adriana Puiggrós ${ }^{25}$, manifiesta que la sociedad está enferma (crisis en la educación), el aprender y enseñar han perdido valor. Abandono y violencia a los cuales están sometidos los adolescentes. Una escuela media que reclama reformas estructurales que ningún gobierno haya tomado la decisión política de realizarlas. Adolescentes como nómades por las calles cercanas a los colegios, sin suficiente motivación por el estudio ni oportunidades de trabajo.

La labor del profesor profundamente descalificada por los adolescentes y por la sociedad se dificulta por la deteriorada situación laborar y carencia de oportunidades para su actualización y perfeccionamiento. Según Emile Durkhein se refería a las insuficiencias en el cumplimiento de la meta más importante de los sistemas educativos modernos: la construcción de los espacios públicos, abarca del conjunto de la población y productores de ciudadanos.

El neoliberalismo pedagógico ha reducido la política educativa transformando pedagogos en contadores. La propuesta neoliberal se compone de dos grandes estrategias:

a) Destrucción del espacio público educativo.

b) Establece nuevos vínculos entre los sujetos, unidos ahora mediante programas de control.

Esta política destruye la capacidad de la sociedad para desarrollar una instrucción pública y sostener instituciones educativas estatales (escuelas, colegios, universidades, programas educativos para adultos, programas de capacitación técnica a través de cuatro movimientos:

\footnotetext{
${ }^{25}$ Adriana Puiggrós. Historia de la Educación en la Argentina. Sujetos, Disciplina y Currículo. En los orígenes del sistema educativo argentino. $1885-1916$.
} 
a) Reducción de presupuestos educativos nacionales.

b) Restricción de uso de fondos externos para políticas sociales y salarios docentes.

c) Introducción del argumento del arancel como forma de financiamiento de los establecimientos educativos de todos los niveles.

d) Descentralización de los establecimientos educativos sin conjurar el peligro de sucesivas transferencias.

Se habla de las garantías, para que los profesores puedan llegar a tener las condiciones aptas para el dictado de las clases de educación física en la escuela donde se encuentran con múltiples miradas y problemas. La utopía la tienen todos por igual, los escenarios de prácticas son diferentes, el estado máximo responsable objetivo de las escuelas como de su seguridad.

Garante: com. (Del ant. alto al. Guardar). Fiador: ser garante de la ejecución de un contrato. (Simón. V. Responsable.) II - Adj. Que de garantía.

Garantía: Responsabilidad asumida por un contratante. Fianza, prenda. Cosa que asegura y protege contra algún riesgo o necesidad. Derechos que garantiza la constitución a los individuos de un estado.

\section{"Conclusiones del Trabajo"}

Luego del abordaje en el capítulo anterior de un análisis de fragmentos de entrevistas, con datos, identificación, consideraciones y cuadro de datos a tener en cuenta pasamos a las conclusiones finales del trabajo de responsabilidad civil.

\section{Responsabilidad Civil}


Llegando a la culminación del trabajo de investigación las conclusiones muestran respuestas a las preguntas formuladas en los capítulos precedentes integradas en un todo a la metodología cualitativa y a la recolección de datos.

En caso del análisis y conclusión del patio escolar como espacio común dentro de la comunidad escolar, requiere también transformar continuamente este espacio lleno de variadas significaciones profundas, fundamentalmente para mejorar y revalorar la educación física en la problemática de la responsabilidad civil. Temas poco estudiado y abordado desde otros enfoques diversos que nos enriquecería profesionalmente.

Las instituciones en que basan sus métodos en el derecho, es algo que debe ser abordado desde los reglamentos en general por las autoridades, sin que puedan ascender en la vía jerárquica. Las vías de resolución son las reglamentaciones, estatutos y contratos. Todos se benefician dentro de la ley. Los métodos basados en el derecho se apoyan en reglamentos y principios fijos, provenientes del derecho, los méritos, la credibilidad y las posiciones.

Aquí están incluidos el litigio y el arbitraje obligatorio en tanto las técnicas para la resolución de conflictos. Terceros tales como árbitros y jueces determinan que tiene la razón frente a un determinado conflicto, tomando como punto de referencia los contratos, los estatutos y reglamentos vigentes.

Una resolución de conflictos planteados en la institución debería ser dada por las autoridades de las cuales dependen las instituciones involucradas. Son ellas quienes conforme a los reglamentos, contratos y estatutos vigentes determinarán el grado de participación de cada institución ya la vez plantearán los mecanismos de castigo para aquellas instituciones que hayan transgredido lo pactado, por ejemplo el ocultamiento de la información.

Este tipo de método está centrado en una visión legalista del conflicto, responden a la vía jerárquica tradicional, dando lugar a la participación, siempre que cuadre dentro de las reglamentaciones vigentes. Estas respuestas al conflicto suelen tener lados positivos y negativos. No es la regla la que nos protege, somos nosotros los que protegemos la regla. La institución es una cuestión de concertación, las reglas que norman una institución no alcanzan nunca a abarcar o a incluir el conjunto de situaciones que se generan en su interior, tampoco pautan totalmente las actividades 
que allí se desarrollan. Por muy minuciosa que sea la reglamentación hay espacios no normados.

Los espacios del patio permiten a los actores hacer uso de su libertad y desarrollar comportamientos de cooperación o de resistencia a los objetivos institucionales. La negociación, en este tipo de cultura institucional existen diferentes sistemas de poder, entre ellos el sistema de poder contractual. Este sistema se base en la adjudicación de poder, durante un tiempo preciso.

Conforme a la legislación actualmente vigente (artículo 1.117 Código Civil), el único legitimado pasivo (demandado o responsable) conforme a un factor de atribución objetivo sin importar su culta, será el propietario del establecimiento educativo, sea público o privado.

El legitimado activo (reclamante) puede ser la víctima o un tercero, y el propietario del establecimiento deberá responder siempre que se trate de daños sufridos o causados por los alumnos menores de edad, mientras se encuentran bajo la vigilancia de la autoridad educativa. Solo podrá eximirse de responsabilidad el propietario del establecimiento probando que el daño se produjo debido a un "caso fortuito" con los alcances que se explicó durante la investigación.

Respecto a los docentes, maestros, profesores, directores, preceptores, etc., solo responderán por los daños sufridos o causados por sus alumnos, si la reclamante prueba que existió en el hecho dañoso, culpa o dolo del docente, conforme a las normas generales de la responsabilidad civil aplicables a cualquier persona.

Si fuera condenado en forma recurrente el propietario del establecimiento educativo y el docente que ha actuado culposamente y el primero abona la totalidad de la indemnización, tendrá luego una acción de repetición contra el docente responsable.

A fin de evitar el surgimiento de dichas responsabilidades es importante la formación y la clara conciencia que se debe brindar una vigilancia activa y permanente a los alumnos a cargo, teniendo en cuenta los recaudos que pueden tomar para cumplimentar la obligación de seguridad que comprende tanto la integridad física como psicológica del alumno. 
A modo de clarificación en las conclusiones, las normas que fundamentan la obligación de reparar los daños causados a otros son tan antiguas como nuestro sistema jurídico, por lo que desde que existen escuelas o patios y docentes tanto los alumnos como sus padres o cualquier tercero que sufra un daño originado en el quehacer educativo o causado por las "cosas" de la escuela, pueden demandar resarcimiento.

Desde 1997, con la modificación del artículo 1.117 del Código Civil, quedo superada la presunción de responsabilidad de los directores que regía desde 1869, en relación con los daños causados por alumnos. A pesar de que las normas ahora favorecen al docente directivo, la preocupación por las consecuencias de hechos de responsabilidad aumento respecto de épocas pasadas y se instaló como problema cotidiano.

Desde estos últimos 10 años, el tema tiene una importante presencia en los patios escolares, es motivo de desvelo de directivos y docentes de educación física en general, originando la proliferación de documentos de contenido jurídico destinados a un público determinado que requieren capacitación al respecto.

En la actualidad, es frecuente la consulta al abogado y la concreción de demandas por daños, a veces en casos de responsabilidad muy clara. El saber sobre la responsabilidad civil es técnico y su contenido jurídico debe ser abordado científicamente. Cada caso que uno pudo entrevistar sobre daños es especial y merece un análisis particular en el cual confluyen algo más que las normas de un capítulo del Código Civil.

Entiendo que podría ser contraproducente algún tipo de difusión de conocimientos fragmentados sobre un solo aspecto de la ciencia del derecho que abarca casi una materia en la carrera respectiva y que forma parte de un sistema jurídico amplio.

La preocupación de los profesores de educación física en las prácticas profesionales en el espacio del patio no solo pasa por saber más o menos de responsabilidad civil con sus prácticas o si es responsable con su función sobre la cual conoce cada uno por formación y experiencia. 
En algunos casos de la investigación ha sucedido que un profesor preocupado por actuar a resguardo de la responsabilidad civil que pudiere caberle, actúo inseguro y vulnerable desviando su atención de aquello por lo que realmente debía preocuparse.

Si ocurriera algún hecho por resarcimiento del alumno en el patio o un tercero, el camino a seguir es el del pedido de asesoramiento y patrocinio profesional denunciando el hecho a la Dirección General de Cultura y Educación y a la compañía Aseguradora, siguiendo el mecanismo administrativo correspondiente.

Respecto al ámbito de aplicación, los propietarios responden cuando el alumno que cause el daño o el que lo sufra dañando o dañador se halle bajo el control de la autoridad educativa, comprendiendo no sólo el daño acaecido bajo la autoridad del director, sino aquellos causados estando el alumno menor bajo el control de personas que, incluso, no son típicamente docentes pero que forman parte de la organización, como el portero, secretario, bibliotecario, etc.

También será responsable el propietario del establecimiento si el alumno se halla o debiera hallarse bajo el control de la autoridad educativa, ejemplo daño causado o sufrido por el alumno que se escapa del establecimiento por falta de control.

El alumno se halla bajo ese control tanto cuando desarrolla tareas calificadas de instrucción escolar o curricular, como cuando realizar actividad extraescolar bajo el control del establecimiento (por ejemplo actividades deportivas, centro de estudiantes, torneos bonaerenses), si dichas actividades extraescolares realizadas dentro del recinto del establecimiento son conocidas y toleradas por el mismo. Quiere decir que se compadece con las modalidades actuales de la educación institucionalizada, que, en orden a una formación integral del educando, no limita sus actividades a los patios, sino que se orienta a la realización de otras de diferente naturaleza, incluso deportivas, que no necesariamente tienen lugar en el ámbito físico del patio en el que se desenvuelven las clases de educación física.

Siempre y cuando las prácticas se desenvuelven se realicen bajo el control y autoridad del establecimiento o sus dependientes. Si se trata de actividades organizadas y controladas por el titular del establecimiento, por sí o a través de sus empleados (directores, vice-directores, profesores, maestros o preceptores), estarán alcanzados por el sistema de responsabilidad del artículo del Código Civil N 1.117. 
Prever también como requisito para que exista responsabilidad del propietario del establecimiento educativo que el daño se hubiera producido durante el desarrollo de la actividad escolar, extraescolar y complementaria cualquier sea el día, la hora y el lugar en que se produzca el daño.

El ámbito temporal de aplicación, no hay precisiones en la norma que permitan establecer con exactitud cuándo comienza y cuando finaliza el control de autoridad educativa. La relación entre el alumno y el propietario del establecimiento es de carácter contractual por lo tanto, de la interpretación de las cláusulas expresas o tácitas que se efectúe, surgirá a partir de qué momento el alumno ingresa en el ámbito de vigilancia del propietario del establecimiento. Lo mismo sucede con relación a la conclusión de dicho control. Cada contrato de enseñanza tiene sus características particulares en cuanto a la extensión horaria, conforme las actividades que el establecimiento prevea.

No hay que atenerse en horarios fijos, entendiendo que resulta totalmente arbitrario considerar que ella existe si el daño se produjo 5 minutos antes de comenzar o terminar el horario escolar y que no 1 minuto después. No obstante el horario de ingreso del deber de vigilancia, independiente de sí el alumno tiene la posibilidad de ingresar al establecimiento, como sería si las puertas del mismo estuvieran cerradas.

El horario de ingreso previamente estipulado entonces, cualquiera que sea la actividad escolar, fija el inicio del deber de vigilancia si el alumno se pone a disposición. Es decir, que si el alumno no ingresara al establecimiento, a pesar de estar las puertas abiertas, el deber de control y por tanto la responsabilidad del establecimiento no existe.

Respecto a la finalización del ámbito de aplicación de la responsabilidad, sigue el mismo criterio que en el inicio, cuando finaliza el horario de clases previamente estipulado y el alumno sale del establecimiento, cesa el deber de la custodia o dirección del menor.

Si es habitual que los alumnos queden en el patio de recreo un corto espacio de tiempo después de terminada la jornada antes de ser recogidos por sus padres o trasladarse a su domicilio, se deduce que los padres cuentan con que hasta entonces están vigilados por el personal del establecimiento, como así también cuando los docentes se hubieran comprendido a cuidar el cruce de los niños a la salida del 
establecimiento u organizar sistemas de seguridad para la salida, como las barreras de alumnos.

Si el alumno concurre al establecimiento fuera del horario previamente estipulado y sin que ello haya sido ocasionado por razones educativas, el propietario no responderá por ningún daño acaecido en ese momento.

El ámbito espacial de aplicación en las salidas, se debe señalar que si el daño se ha producido dentro del establecimiento debe presumirse que acaeció mientras el alumno estaba bajo el control de la autoridad educativa. Si el daño se ha producido fuera del establecimiento, en el complejo polideportivo por ejemplo o en otro lugar al aire libre donde los alumnos acostumbran a recibir las clases de educación física, si éste se produce en el horario de dictado de la asignatura.

Si el daño se causó fuera del establecimiento pero tuvo su causa dentro de él tampoco hay dudas sobre la responsabilidad del propietario (por ejemplo, el daño que se produce a una persona con un objeto que fue arrojado por un alumno desde la ventana del colegio). No se descartan los daños que se produzcan estando el alumno fuera del establecimiento en horario escolar, si éste se escapó del mismo por falta de control.

Durante las excursiones o viajes organizados bajo el control de la autoridad educativa, los mismos pueden clasificarse como viajes de estudio, de esparcimiento o recreo. La regla aplicable es la siguiente: si el viaje o paseo ha sido contratado por los alumnos totalmente al margen del control del establecimiento educativo, no será aplicable el artículo 1.117, por el contrario, si existe una participación o bien la posibilidad de vigilancia por parte de aquél, la obligación de resarcir los daños, tanto si se producen en el alumno como si éste los produce a terceros, se pondrá en actividad.

Quedará el arbitrio judicial determinar el nivel de injerencia que tiene la autoridad educativa en la realización del viaje. Con respecto al transporte escolar, si el contrato es celebrado por los padres de los alumnos con transportistas no dependientes del colegio, a los efectos de que en los días hábiles escolares trasladen a sus hijos desde sus hogares hasta los establecimientos educativos y los retornen, la responsabilidad del establecimiento educativo no se encuentra comprometida. Distinto es el caso de los colegios que en el contrato de enseñanza incluyan el transporte de los alumnos. 
Los propietarios del establecimiento educativo no se eximen de responsabilidad probando su falta de culpa o la asunción de todas las diligencias debidas, como así en cambio pueden hacerlo el docente o directivo. Sólo puede eximirse probando que se ha roto el nexo causal, que ha ocurrido un caso fortuito, así será responsable el propietario del establecimiento educativo por el daño sufrido por un alumno como consecuencia de un golpe con la pelota de voleibol mientras practicaba dicho deporte en la clase de educación física.

Cuando se utiliza la expresión responsabilidad concurrente, se quiere significar que hay más de un responsable que origina o contribuye a ocasionar el daño, cuya reparación se persigue. Por lo tanto al haber más de una persona responsable (legitimado pasivo), va a surgir más de un obligado al pago. Conlleva a que el órgano decisorio, al momento de sentenciar y teniendo en cuenta las particulares circunstancias de la causa, puede atribuir en porcentajes la responsabilidad que cada sujeto procesal tuvo en el hecho, de manera de distribuir o compensar en su caso, el monto a resarcir. El artículo 1117, consagra la responsabilidad directa del centro educativo. No implica que los docentes y directivos queden exentos de toda responsabilidad, si actuaron con dolo o culpa.

Es importante concluir diciendo que es muy importante el debido diligenciamiento del formulario de cada denuncia. El establecimiento no siempre debe responder de todo daño a los estudiantes, pues en el hecho debe tenerse en cuenta la capacidad de los niños para herirse sin culpa de aquellos que los vigilan.

Hay casos en que aún con todos los cuidados no ha podido evitarse por ser un hecho imprevisto e inevitable. El auge de la responsabilidad civil ha sido generado por todo un vasto movimiento situaciones que se produjeron en los patios escolares como también de daños acontecidos en diversas circunstancias.

Pensar en una escuela menos verticalista, más participativa, en la que los actores en su totalidad y los sectores que trabajan tengan más protagonismo, marcando los roles de cada uno y cuáles son las jerarquías. En una sociedad que históricamente desacató y descreyó de las normas y leyes, trasladándose a los niños y jóvenes.

El estado, en este caso la Dirección General de Cultura y Educación es el garante de las escuelas que están funcionando y responsable primario como propietario de las mismas. 
Las Instituciones que ponga un establecimiento a disposición de otras personas para que practiquen un deporte, asumen una obligación de seguridad en cuanto al uso de instalaciones. La obligación que tiene la provincia de reparar el daño causado al actor, la culpa de la víctima en caso de existir, no podía jamás compensarse con la del poder público, ya que el Estado, más que nadie ,debe obrar con prudencia y pleno conocimiento de las cosas.

Al inicio dejo aclarado que la responsabilidad civil es una figura jurídica que funciona del ámbito del Derecho Privado (Civil) y sirve para colocar en cabecera del autor de un daño. Gracias a la evolución de algunas normas del código civil aplicables a las prácticas del profesor de educación física, en el caso del artículo 1.117 que según el texto actualizado y vigente a la fecha dice:

Los propietarios de los establecimientos educativos privados o estatales serán responsables por los daños causados u sufridos por sus alumnos menores cuando se hallen bajo el control de la autoridad educativa, salvo que probaren el caso fortuito. Los establecimientos educativos deberán contratar un seguro de responsabilidad civil. A tales efectos, las autoridades jurisdiccionales, dispondrán las medidas para el cumplimiento de la obligación procedente. La presente norma no se aplicará a los establecimientos de nivel terciario o universitario.

Los patios de educación física en el distrito: No son tenidos en cuenta en las prioridades de la unión educativa de gestión distrital, los arreglos de escuelas, las necesidades escolares superan el escenario del profesor. En el capítulo de patios de educación física en la investigación fundamenta esta conclusión. Reglamentar los mismos para que tengan un porcentaje de seguridad elevado sería denunciar las falencias actuales del distrito en materia de espacios adecuados para el trabajo de la educación física, sería cubierto con un plan nacional, programa provincial y proyecto distrital.

Los Profesionales siguen preocupados por el actuar a resguardo de la responsabilidad que pudiera caberle, actuando en oportunidades inseguros, distrayendo su atención en algunas cuestiones legales que antes no se tenían en cuenta. Impacta la responsabilidad civil en las prácticas del profesor, aunque en estos últimos años se nota una leve mejoría en la preparación docente como también al cuidarse profesionalmente se cuidan personalmente. 
Se preguntan ¿cuál es el ámbito espacial de la responsabilidad?, el propietario del establecimiento responde cuando el alumno sufre un daño hallándose en la escuela y se extiende a las salidas programadas por el colegio. Tienen en cuenta la normativa actual y única para el sistema educativo.

Las normas fundamentan la obligación de reparar los daños causados en las prácticas escolares, desde que existen las escuelas y los patios como los docentes. Cualquier tercero que sufra un daño originado en el hacer educativo o causado por las cosas de la escuela puede demandar resarcimiento.

Con la modificación del artículo del Código Civil 1.117 quedó superada la presunción de responsabilidad de los directores, en relación con los daños causados por alumnos.

Captan los profesionales el problema pero siguen faltando conocimientos de la norma legal, como también el gran debate actual. Se percibe algunos cuidados respecto a la problemática no todos, se siguen descuidando detalles muy importantes a la hora del daño.

El estado debe garantizar la educación en condiciones mínimas de seguridad como un lugar digno para la práctica profesional, un Plan Nacional, un Programa Provincial y Proyectos Distritales se podrían poner en práctica para solucionar la problemática de la falta de escenario adecuado.

En el hecho de responsabilidad civil el perjudicado tiene el derecho de ser restituido a la situación que se encontraba antes de que sucediera el hecho que dio lugar el daño, este comprende no solo el perjuicio efectivamente sufrido, sino también la ganancia de que fue privado el damnificado por el acto ilícito.

De acuerdo con la investigación el profesional que tiene un problema de responsabilidad civil acude a su directivo, inspector o gremio para asesoramiento, sería importante tener abogados de acuerdo con la modalidad o nivel para acompañar al docente. El estado parece en los últimos años no haber tomado la iniciativa sobre la problemática del patio de educación física a los efectos de trabajar en la problemática, siendo el garante fundamental de la escuela pública. 
El saber sobre la responsabilidad civil es técnico y su contenido jurídico debe ser abordado científicamente, mereciendo un análisis particular en el cuál confluyan alga más que las normas de un capítulo del código civil. No solamente el artículo 1.117.

Falta asesoramiento en el área legal de las direcciones de la modalidad de educación física correspondiente, como también socializar el tema y las responsabilidades como la obligación de responder por las consecuencias dañosas por sus propios actos, en especial aquellos producidos con dolo, culpa o negligencia, dañan a otros.

Los profesores del patio de la escuela que están en el contexto actual están superados por entorno que los rodea a las prácticas. Esta problemática permitió desnudar ciertas falencias sociales con esta originalidad de propuesta a mi entender.

La gran variedad de problemáticas en el sistema educativo hace que la responsabilidad civil sea una más, aunque de acuerdo a las circunstancias vividas por cada actor en el contexto determinado que trabaje dicho problema, aparece en el momento menos pensado y se actúa en consecuencia como estén preparados fundamentalmente con el problema. No están todos preparados para el mismo.

Pareciera que las mismas en bajo porcentaje no son tenidas en cuenta, tomando como referencia a las últimas construcciones edilicias correspondientes a los patios escolares, gimnasio, piletas y escenarios para la educación física no llegaría al $20 \%$ en los planes de obras desde los últimos años, consultando el $A B C$ de la dirección general de cultura y educación.

El consejo escolar según la Ley 13.688 son órganos desconcentrados de la dirección general de cultura y educación, en el área infraestructura escolar se prioriza los arreglos en general de las escuelas de educación inicial en el último año, como las escuelas primarias y secundarias.

Se nota la falencia en el distrito de carencia edilicia, todas son prioridades, menos educación física, a pesar que anualmente la provincia autoriza algunas obras, las mismas salen de las reuniones de la unión educativa de gestión distrital o alguna obra gestionada políticamente.

La buena voluntad del docente es la clave, la realización de cursos de primeros auxilios o de técnicas de bioseguridad es producto de inquietudes personales que 
muchas veces son transmitidas o auspiciadas por privados. En el año 2005, más precisamente el martes 15 de febrero del 2005 el director general de cultura y educación de la provincia de buenos aires, participo del lanzamiento del programa de gestión integral de riesgos en las escuelas, en el marco de una jornada de trabajo escolar donde asistieron consejos escolares y miembros de cooperadoras escolares de todos los partidos bonaerenses.

Se abordaron temas de normas de seguridad vigentes en los edificios escolares y las capacitaciones sobre cuestiones técnicas que deben tenerse en cuenta en las escuelas. Se trataron cuestiones operativas para ejecutar el programa en cada distrito, en forma descentralizada, a través de los consejos escolares.

El programa de gestión integral de riesgos en las escuelas, iniciativa diseñada por la dirección provincial de infraestructura escolar de la cartera educativa, que tiene como principal objetivo definir acciones preventivas ante posibles situaciones de riesgo dentro de los establecimientos educativos, 4 años después no tiene resultados favorables, por lo menos en el distrito que investigo.

Reformular los sistemas de seguridad con que cuentan actualmente las escuelas, como así también integrar a toda la comunidad educativa en una tarea de capacitación constante sobre controles, medidas de seguridad y evaluación de edificios escolares, entre otros puntos.

La unidad educativa de gestión distrital coordinada por un inspector distrital, en la que forman parte consejo escolar, representante municipal, asuntos docentes, centro de investigación educativa, gremios no docentes, gremios docentes, entre otros. Es ahí donde se debate que política distrital se lleva a cabo durante cada año, diagnosticando, diseñando, ejecutando y evaluando las acciones del distrito.

Las prioridades de infraestructura, seguridad, prevención, patios de educación física si bien se habla de las problemáticas, la toma de decisiones para autorizar construcciones de infraestructura siempre pasa por las escuelas en general.

Se sigue actuando por sentido común, se toman los permisos sociales y hasta que no ocurre el hecho se dan cuenta que podría haberse previsto con antelación el daño. 
A diferencia de la responsabilidad penal y la disciplinaria, la responsabilidad civil no tiene una finalidad represora de determinadas conductas, sino que su objetivo es resarcir a la víctima de acciones u omisiones con resultados dañosos.

El daño es el centro del problema y es de él que nace la obligación de reparar que se caracteriza expresándose en la sanción que impone una sentencia de reparar el daño.

La mayoría de los profesionales aún no tienen conocimiento del saber, que cuando mayor sea el deber de obrar con prudencia y pleno conocimiento de las cosas, mayor será la obligación que resulte de las consecuencias posibles de los hechos.

La problemática social impacta en la escuela, se contiene, se atienden los comedores, disciplinan, participan de programas provinciales y lo que es importante en los actos públicos poder acceder a puestos de trabajo que escasean. Si hubiera que reglamentar la educación física con los patios adecuados podría tambalear la educación física actual.

Del dicho al hecho, cambian. Algunos discursos pareciera que tienen el conocimiento pero al observar sus prácticas no cambian.

Al analizar el tema o debatirlo podría llegarse a que todos los profesionales puedan ser más diligentes, previsores, prudentes, hábiles, pues de otro modo responderían con sus propios actos. A veces con el deseo de colaborar, compartir, integrar, hacer lo que otros quieran que hagan, transfieren la responsabilidad y cuando aparece el daño tiene que hacerse cargo.

Aparece la culpa, que no actuar con imprudencia, con negligencia, con descuido y si esto deriva en daño, ese daño que ha sido precedido de un actuar con culpa se convierte en un daño causado por culpa. El código civil funda la imputación en la previsión y caracteriza la culpa y el dolo de acuerdo a la previsibilidad.

En las clases observadas aparecen las omisiones de aquellas diligencias que exigiere la naturaleza de la obligación y que correspondieren a las circunstancias de las personas, del tiempo y del lugar. Aumenta la misma por la falta de seguridad en los patios, los problemas edilicios, la falta de playones adecuados para la práctica y la falta de conocimiento en estos temas. 
Pensar antes de actuar y no tomar decisiones equivocadas, en una sociedad donde se necesitan normas adecuadas a los contextos ayudaría a que el profesional pueda tener un comportamiento atento, previsor e inteligente.

Los patios de educación física aparecen en el distrito divididos en espacios verdes, playón, salón de usos múltiples, gimnasio, poco espacio disponible para la práctica y reducido. Es problemático cuándo la escuela carece de espacio para el recreo o la clase de educación física, lo que sumado a los edificios históricos habría que buscar otros espacios para la práctica en los establecimientos carentes de lugar.

Al indagar sobre los datos obtenidos en el año 2010 en las escuelas primarias sobre datos de infraestructura permite observar la multiplicidad de lugares físicos en cada escuela con carencias fundamentalmente del patio escolar que brinde las condiciones mínimas de seguridad y de un lugar básico para las clases de educación física.

La responsabilidad civil a la luz de los acontecimientos, pareciera estar más invisible que nunca para quién tiene como prioridad buscar un trabajo en condiciones dignas sin tener que prescindir de escenario adecuado.

La vigilancia por parte del cuerpo docente resulta dificultosa, en escuelas donde se encuentran cientos de alumnos, lo que la hace excesiva e injusta, sumados a la falta de espacio en la escuela para educación física, esa responsabilidad crea en el profesor como en el directivo angustias. No pueden dedicarse con sana tranquilidad a sus labores específicas.

El director es un simple dependientes de la dirección general de cultura y educación propietaria del establecimiento educativo, sin embargo se cargaba al profesional con los hechos del cuerpo docente y del personal que él no puede elegir. Tales son los casos de encuentros de juegos masivos, programas provinciales, torneos deportivos, carreras pedestres, etc.

Aumentan considerablemente las actividades extraescolares y complementarias de la educación física en cada gimnasio, al aire libre, en contacto con la naturaleza como también se habla de la contención, integración por lo que la tarea del profesor se multiplica a los efectos de contribuir a la formación integral del alumno. 
Consecuentemente se han visto ampliadas considerablemente las posibilidades de riesgo sumadas a la falta de infraestructura adecuada para las prácticas.

En cambio si el alumno sale del colegio, concluido el horario escolar, sufre un accidente de tránsito, se considera que no podría imputarse responsabilidad al propietario del establecimiento, en razón de que no puede extenderse la guarda asumida por éste hasta ese límite.

Es importante mencionar que hay casos en el patio en que aún con todos los cuidados no ha podido evitarse por ser un hecho imprevisto e inevitable. El caso fortuito constituye una eximente de responsabilidad y por ende interrumpe el nexo casual. A los efectos de la procedencia del caso fortuito como eximente de responsabilidad.

Algunos de los objetivos en esta investigación tienen que ver con analizar los discursos de los profesores de educación física en la responsabilidad civil, analizar los problemas, cómo también explorar los impactos respecto al tema. Los conceptos de norma y ley en particular fueron analizados. Los posibles beneficiarios en este trabajo seguramente serán los profesionales de la educación corporal que con las conclusiones podrán iniciar aún más el debate de la responsabilidad civil en las prácticas del profesor de la escuela.

Conocer la historia sobre la responsabilidad civil en el contexto del patio permitió revisar el pasado, analizar el presente e intentar encontrar respuestas sobre múltiples problemas que uno va descubriendo con la problemática.

Dentro del contexto del patio escolar escenario del profesor de educación física como en las políticas del cuerpo la responsabilidad civil tiene motores poco explotados.

La lucha por el espacio del profesional en el patio como de su seguridad no es de ahora sino de muchos años atrás, una educación física sin identidad con problemáticas de multiplicidad y desacuerdos entre la teoría y la práctica. Un espacio en el que el cuidado del cuerpo no normado es fundamental. No podemos negar que cada día nos reaseguramos de nuestro propio "espacio" que es nuestro propio cuerpo, primer espacio que sentimos, percibimos, estructuramos y de nuestra experiencia motriz muy particular en la historia de cada persona. 
El juego aparece en el patio del profesor de educación física como configuración de movimiento como el deporte por lo que requiere cada vez más de profundos análisis, discusiones y reflexiones sobre como interactuamos, abordamos y nos reapropiamos de este espacio de juego ya sea defendiendo, atacando, compartiendo o poniéndonos a distancia del otro, de los otros.

Si le sumamos las condiciones edilicias en que las prácticas se desarrollan, las clases actuales, el impacto de las responsabilidades, las obligaciones, las normativas, los códigos en el patio que se encuentra encuadrado dentro de un contexto llamado escuela las miradas son demasiadas. Entiendo que es necesario tomar decisiones respecto a un completo estudio como profundo para reconocer, revalorar, replantear y transformar continuamente este espacio lleno de variadas "significaciones profundas".

El patio escolar, es realmente una dimensión escondida, falta estudiarla y abordada desde otros enfoques en el cual las prácticas del profesor de educación física muestran ganancias y pérdidas respecto al problema de responsabilidad civil. El antes, el durante y el después del daño es un análisis a tener en cuenta en el accidente relacionado con lo sufrido por el alumno a nuestro cargo.

Prever y anticiparse a posibles caídas que no siempre son evitables mediante indicaciones y consejos, pues fácilmente pueden responder a descuidos o torpezas de los propios participantes en las prácticas. Antes, durante y después los profesores están bajo la lupa de la responsabilidad civil.

El título profesional los habilita para el desempeño de múltiples tareas, que son requeridas en la escuela por la directora, equipos docentes, fechas patrias, encuentros deportivos escolares, torneos juveniles bonaerenses, fiestas de educación física, día del niño, etc.

Los profesores cumplen con instrucciones a cargo acerca del modo y manera de cumplir con lo encomendado por la dirección de educación física de la provincia de buenos aires dependiente de la dirección general de cultura y educación de la provincia., para ello el docente mensualmente cobra en contraprestación. Para ello cumplimentan la declaración jurada de horarios al inicio de cada ciclo lectivo antes de comenzar con las prácticas escolares en el patio, oportunidad que no deben desaprovechar los profesionales para aclarar el lugar de trabajo, los horarios, las circunstancias de trabajo. 
Velar por la seguridad de los alumnos a cargo como responsables durante la clase. Las medidas de prevención como conocer el marco legal y las responsabilidades que contraemos civilmente y profesionalmente en el patio durante el trabajo son muy importantes. Muchos de los accidentes son evitables guardando adecuadas medidas de seguridad. Al parecer el docente no tiene en cuenta que algún hecho lo puede afectar en la carrera profesional, algunos consideran a la educación física como una actividad riesgosa.

Verificar las medidas de seguridad al inicio del año antes de las prácticas es fundamental, a los efectos de evitar posibles lesiones en las prácticas en actividades físicas escolares. La prevención de cuerpos es muchas veces tomarse el tiempo para diferenciar posteriormente la alegría y el drama en los posibles accidentes.

La presencia activa como alerta en todo momento desde el inicio de la práctica profesional hasta la finalización, tener los conocimientos de los posibles riesgos de la actividad y ser prudentes al proyectar acciones que eviten un posible daño físico. Las medidas de prevención para evitar o disminuir al menos la responsabilidad civil pareciera que son infinitas para que no ocurra el daño.

La ley impone a quién presta el servicio de modo organizado el deber de prestación sin producir daños. Todo accidente es prevenible y evitable, es por eso que el deber del profesor de educación física esta agravado por el título profesional. El estado garante de la seguridad escolar debería tomar conciencia de la difícil situación de educar cuerpos en los patios escolares en muchos casos inapropiados y sin elementos para responder en caso de los accidentes.

Prestar la debida atención de los alumnos antes, durante y posterior a la clase. Nunca abandonar la clase y dejar a los alumnos solos. Los elementos o materiales de educación física que puedan ocasionar peligros en las clases deben ser retirados. Las colchonetas, cajones de salto, tablas de pique en mal estado pueden ocasionarnos un dolor de cabeza a todos. Si se trabaja al aire libre tener muy en cuenta los pisos mojados o resbaladizos como los de superficie deslizante.

Los ejercicios programados que no son adecuados para la edad no realizarlos. La disciplina de los alumnos en las hileras tiene que tenerse en cuenta, también cuando son grupos numerosos y se divide la clase sin que el profesor esté al tanto de los 
cuidados de la integridad física de los alumnos. Toda práctica debe estar planificada anualmente y no realizar actividades que no estén reconocidas por la Inspección de educación física y que puedan ocasionar algún riesgo.

Los ayudantes en las clases que en alguna oportunidad son alumnos a cargo de otros alumnos tener mucho cuidado por los descuidos como la distribución de los mismos en el patio o complejo polideportivo (lanzamientos de bala, disco, jabalina, martillo, etc.). aconsejables que permitan observar pero que no les ocasiones riesgo alguno. Las condiciones climáticas son importantes al aire libre para su desarrollo. Los espacios inadecuados para la práctica de educación física se deben tener en cuenta como el incumplimiento del horario pautado en la declaración jurada de horarios.

Los ejercicios intensos sin conocer el estado de buena salud del alumno que no paso por el reconocimiento médico. Las líneas demarcatorias para las canchas tienen que tener suficiente espacios reglamentarios y alejados de paredes, ventanas, alcantarillas, etc. Las superficies deterioradas como las deslizantes son un problema para los posibles daños que puedan ocurrir. Los llamados telefónicos no deben ser contestados cuándo estamos dictando clases, no debemos dejar solos a los alumnos.

Todas las situaciones en cualquier circunstancia, tiempo y lugar no deben incomodar como también entender que se debe al desconocimiento que existe sobre la responsabilidad civil. Uno puede tener una actitud positiva y activa pero nunca indiferente como tener una visión negativa del problema. Estar obsesionado como mencionar siempre estos temas como para negarse a todo proyecto por si nos pasa algo, es decir no hacer nada no soluciona el problema.

Especializarse en estos temas ayuda al profesional para iniciar un camino con una mirada y visión de las prácticas de educación física distinta a las tradicionales de tantos años. Obrar imprudentemente (por hacer aquello que no debía) o negligentemente (por no hacer lo que debía) puede considerarnos responsable civilmente en una demanda. Actuar diligentemente y prudente en las prácticas del patio o fuera del mismo cuándo organicemos una salida fuera de la escuela.

Tener en claro que hacer, porque, hacia quién está dirigido como estar atento a las tareas profesionales es muy difícil que tengamos algún problema o inconveniente legal. Conducirnos entre el defecto y el exceso es tener en cuenta el equilibrio ser razonable asumiendo la responsabilidad con toda naturalidad. Saber cuáles son los 
derechos y obligaciones permitirá decidir, planear, ordenar, trabajar, con nuestros alumnos mejor.

Entendiendo que por las circunstancias en que se realiza en la actualidad de la educación física puede considerarse riesgosa hay mucho por mejorar y modificar. Los compromisos para que las actividades sean realizadas correctamente, en un ámbito seguro anticipándose a distintas circunstancias que resulten previsibles a los trabajos en el patio como pintado de líneas, colocar tableros, arcos en condiciones, redes y par antes para voleibol, etc. Todos los niveles de decisión están comprometidos: profesores, directores, maestros, etc.

Proponer una mejor y responsable educación física no significa prohibir o impedir sino implica defender la actividad física y deportiva para evitar la falta de previsión. Como profesores se puede contribuir a plantear que los proyectos como los programas sean los adecuados en defensa de la educación física. Empezar a tratar los temas en conferencias, charlas, debates es muy importante en la actualidad para intercambiar experiencias y trabajar mejor.

Las normas integran válidamente un ordenamiento jurídico, son válidas cuándo han sido dictadas por el órgano mediante el procedimiento y cuyo contenido debe ajustarse a normas superiores. Estas normas se interrelacionan de forma tal que algunas comparten un mismo plano jerárquico mientras que otras están en relación de subordinación respecto de otras superiores.

El sistema convive con ordenamientos jurídicos yuxtapuestos (el nacional y el provincial). En la cima de las jerarquías de las leyes, están la constitución nacional y provincial que establece la forma de gobierno. La constitución nacional ha reservado la atribución del dictado del código civil. La aplicación de las normativas exige su previa interpretación.

La constitución es la ley fundamental de la organización, determina los contenidos de las leyes y regula la creación de las mismas. Es la ley superior y a partir de ella surgen otras leyes que no pueden ser contradictorias. La norma regula los actos y las relaciones, aplicables en tiempo y lugar, con una ley que mande o se prohíbe o permite una cosa. El decreto da aclaración acerca de las Leyes pero no puede ampliar el contenido de las mismas. La resolución, es una orden emanada de una autoridad 
superior a los dirigidos, generalmente son por escrito. La ordenanza, es una disposición dictada por el municipio para el gobierno de la respectiva ciudad.

Las normas regulan la conducta de las personas en un tiempo y lugar determinado, las actividades que desarrollan los profesores en el patio si reflexionan sobre sus prácticas, se darían cuenta que en la gran mayoría de las normas jurídicas las desconocen. Las normas jurídicas determinan cuales son los actos permitidos o no realizables.

Convivimos en un modo permanente con normas de toda especie que se encuentran relacionadas entre sí y configuran un ordenamiento. Como personas físicas (sujeto de derecho), estamos obligados a respetar y cumplir con las normas de carácter general (nacionales), civiles, penales, constitucionales, laborales, administrativas, ley del deporte, ley del doping, etc.

También estamos obligados a respetar las normas provinciales, municipales, otras. Cuando viajamos a un encuentro distrital, regional y provincial dirigimos el equipo de la escuela y estamos representándola. Tenemos normas a respetar, propias como el estatuto, y otras que reglan la conducta a cumplir dentro y fuera de la institución mientras la representamos.

Las acciones humanas son susceptibles de ser consideradas en relación, entre los sujetos o entre estos y las cosas, o entre estos y el estado. Para el derecho las conductas serán lícitas o ilícitas, permitidas o prohibidas, porque cualquier conducta siempre tiene relevancia jurídica. El derecho esta siempre desde el momento en que hay un grupo social en la organización.

Este conjunto de reglas de conducta que deben cumplir obligatoriamente y cuya observancia puede ser impuesta por la autoridad legítima. Algunos sostienen que la garantía de las condiciones de vida en la sociedad, está asegurada por el poder coactivo del estado.

El derecho objetivo, sería la existencia de principios y normas que regulan la convivencia humana. El derecho subjetivo, sería la facultad que las personas físicas o jurídicas tienen para realizar ciertos actos permitidos que la ley no prohíbe. 
No hay derecho si no puede ser exigido coactivamente, la noción de derecho es considerado como una forma de control social. En la escuela reciben los profesores las circulares que es una notificación que se da generalmente entro los pares de educación física, orden dirigida por una autoridad a todos o algunos. También están las directivas que son de aplicación exclusiva para un establecimiento educativo, por ejemplo la dada por la director de la escuela.

Interpretar es buscar sentido a las normas y el valor para ser aplicada a las relaciones jurídicas, teniendo en cuenta las circunstancias del caso. Las fuentes del derecho son: la ley, la jurisprudencia, la costumbre y la doctrina. La ley en sentido amplio se entiende como normas jurídicas reguladoras de los actos y de las relaciones humanas.

La costumbre es la conducta repetida, la costumbre jurídica es la repetición de conducta en interferencia subjetiva. La jurisprudencia es la interpretación que de la ley hacen los tribunales para aplicarla a los casos sometidos a su jurisdicción. La doctrina es el conjunto de tesis y opiniones de estudiosos del derecho, que explican y fijan el sentido de las leyes o sugieren soluciones.

Reflexiono sobre la bioseguridad por sobre la responsabilidad civil tratar de bajar a lo concreto y nos encontramos con la problemática escolar en la arquitectura, en el patio con las prácticas del profesor y la responsabilidad civil enmarcado en un problema profesional con motores poco explotados que tiene que ver con políticas del cuerpo.

Involucrándome en los problemas jurídicos, analice un concepto que es la bioseguridad y en la cual los docentes no cuentan con una formación sistemática en técnicas de bioseguridad. En la mayoría de los casos, la preparación depende de la inquietud personal del profesional o de la organización institucional. Las deficiencias que presentan las escuelas públicas donde el cuerpo docente prácticamente no recibe capacitación sobre estos temas y el equipamiento, cuándo hay a veces son aportadas por los docentes y no por el sistema.

No son demasiados los programas previstos para este fin. Los docentes no reciben ningún tipo de capacitación sobre como tienen que actuar ante emergencias, si la tienen es por su interés personal pero no porque esté planificado. En las causas de responsabilidad civil enumeradas en esta investigación podemos observar la intervención del profesor de educación física cuando no debiera hacerlo, pero es por 
una cuestión humanitaria, casi espontánea. Obviamente la persona se va a guiar por su criterio personal, si nadie le indica que tiene que hacer.

Con las distintas causas, estas dejan secuelas y una de ellas es poner en evidencia lo que no se ha hecho o lo que se ha dejado de hacer. La seguridad en la escuela, la provisión de matafuegos y la generación de rutinas de prevención aún son utopías a pesar de que en algún año se inició algún cambio provincial.

Fijar claramente el marco legal de referencia de las acciones es fundamental. Aún falta socializar y difundir la problemática de seguridad en las escuelas como también la responsabilidad civil. La capacitación y la formación de docentes es tarea a realizar en estos temas que siguen preocupando.

También la contratación del servicio de emergencias no es cuestión de competencia distrital, en marzo del 2006 un consejero general de cultura y educación declaraba en un medio periodístico que "es un gran agujero negro del estado" y que la Provincia nunca asumía voluntariamente su responsabilidad.

Sumados a los problemas de la cobertura especial de un servicio de ambulancias públicas, específico para los casos de atención primaria, le genera al estado una demanda para la cual no existen recursos con que cubrirla. Esto pone en evidencia las limitaciones con la que funciona el distrito en emergencias médicas.

En el distrito es evidente que hay un déficit notable en este aspecto ya que, así como hay ambulancias para emergencias para la vía pública, también tendría que haber otras destinadas a la atención primaria dispuestas a asistir a una persona sin recursos que sufre de un cuadro leve o grave dentro del hogar. Esas ambulancias deberían ser las que, llegado el caso, se tendrían que ocupar de ir a una escuela en situación de emergencia.

Esas unidades no existen, ni para la cantidad de alumnos de todas las escuelas del distrito ni para un anciano sin obra social que se cae en la bañera. Sumados a la problemática de infraestructura escolar, los patios siguen ausentes en las construcciones edilicias provinciales, entre el 2005 al 2010 fueron escasos los presupuestos para atender esas demandas. Los gremios docentes desde el 2001 al 2004 denunciaban problemas de higiene y seguridad en las escuelas. 
La investigación de la responsabilidad civil es las practicas del profesor de educación física aportaría no solo a los profesores sino a la docencia en general. Los conceptos de norma y ley en particular son analizados en el escenario de las prácticas. La ley establece límites entre lo permitido y lo prohibido, la norma expresa una cierta gradualidad entre un más y un menos.

Los profesores están superados por el entorno que los rodea en las prácticas del patio escolar, analizar el adentro de las mismas como el afuera de las problemáticas nos permitiría tener un mejor saber y no tener un saber parcializado o una complicación

Como profesionales trabajamos con el cuerpo y con los cuerpos de los alumnos en el patio de la escuela. Nos preguntamos si trabajamos con el cuerpo interno o externo, hay un cuerpo por fuera del sujeto que puede desligarse, cuya mediación está dada por el lenguaje, por el significante, ese lenguaje que nos da la existencia de la misma sociedad y de la cultura.

El cuerpo no nos es dado, sino que se construye con relación a la cultura y el lenguaje. Es una realidad el cuerpo, implica decir que no es primario, que no se nace con un cuerpo. El sujeto es anterior y posterior al cuerpo, y puede permanecer aún después de la muerte del cuerpo.

Es necesario considerar la mediación del sujeto con el cuerpo, lo que no puede construir su cuerpo de modo inmediato. Y esa mediación está dada por el lenguaje. En las escuelas rurales los maestros y los alumnos se preguntan dónde realizar las clases de educación física con los problemas actuales. Poniendo de manifiesto la situación actual de la educación física describiendo los patios la misma resulta complicada ya que habitualmente no existen instalaciones específicas destinadas a la educación física en condiciones.

Si hablamos de las políticas de cuidado en las escuelas públicas, el escenario de las prácticas de la educación física no tiene el mismo reconocimiento del estado al igual que las escuelas. A pesar del problema de infraestructura actual en las escuelas.

Los problemas de infraestructura y de equipamiento se encuentran en el centro de quejas. Estos problemas que padecen las escuelas públicas bonaerenses son planteados en todos los debates, por profesores, padres, alumnos, comunidad en general. Muchos de los padres dicen que con la nueva ley de educación, están de 
acuerdo con un nuevo proyecto, pero entienden que deben resolverse con urgencia los problemas que existen en materia de infraestructura y de personal, además que a la educación deberían tomarla las autoridades como política de estado.

La provincia de buenos aires recaba información para luego planificar una serie de inversiones tendientes a mejorar la infraestructura escolar. Manifiestan que los establecimientos educativos de nuestro distrito no están en las mejores condiciones edilicias, dado que en la mayoría de los casos se trata de construcciones que tienen muchos años.

También comentan a los presentes que también hay que tener en cuenta que existen muchas casas que han sido transformadas en escuelas, que algunos establecimientos no reciben el mantenimiento adecuado y que, en ocasiones, el uso es inapropiado.

La responsabilidad civil modifica las prácticas del profesor de educación física en el contexto del patio escolar a confirmar por los dichos de los actores como de los abogados encuestados o de los directores van modificando cada vez más las prácticas profesionales de los docentes que cuidan cada vez más no solo el cuerpo de los alumnos sino el suyo.

El donde estamos parados los profesores al decir en las entrevistas pareciera que en la incertidumbre de todos los días, preparando las clases y viendo a ver qué pasa o lo que podría suceder, a pesar de ello siguen trabajando dando lo mejor e incluso recuperando esas prácticas perdidas como identificándose con la escuela.

Las reglas se acatan pero no se cumplen dirían los trabajadores de la educación física hasta los permisos sociales se toman a diario con la práctica social pese a la normativa legal vigente lo que supone un riesgo para el profesional que por desconocimiento corre sus riesgos.

La responsabilidad de los padres cesa cuando el hijo ha sido colocado en el establecimiento de cualquier clase y se encuentra de una manera permanente bajo la vigilancia y autoridad de otra persona. Mientras el alumno menor se encuentra en el colegio se desplaza la guarda material del hijo que ejercen los padres. La vigilancia y el cuidado pasan a estar a cargo del establecimiento educativo, esta circunstancia, constituye una de las causas principales que originan la responsabilidad del colegio por los daños sufridos u ocasionados por los alumnos. 
Se entiende por función docente que debe desempeñar el agente en su cargo, conforme a lo establecido en el estatuto, su reglamentación y demás normas vigentes. Entendiéndose por ética docente el respeto de los derechos fundamentales consagrados en la constitución nacional y provincial como las leyes que reglamentan su ejercicio.

La ley regula el ejercicio del derecho a enseñar y aprender en la provincia de buenos aires, conformes a los principios establecidos en la constitución nacional, y los tratados Internacionales incorporados a ella, en la constitución provincial y en la ley de educación nacional. La asistencia a la escuela como la edad mínima para abandonarla está fijada por ley.

Sería importante proporcionar nociones básicas sobre lo que es la responsabilidad civil, creación de una dirección provincial de r. c.

Reflexionar acerca de las cuestiones jurídicas que debe tener en cuenta cada docente a la hora de preparar y llevar a cabo sus funciones en las escuelas, todo ello desde un planteamiento constructivo que no desanime al docente, sino que le sirva para conocer mejor su campo profesional y los modos en los que puede trabajar más seguro.

Si la educación es, indudablemente una actividad humana, cualquier definición de responsabilidad civil que adoptemos, apuntará a la realización de deseos o expectativas puestas en el otro. La educación al hablar de patios siempre ha guardado una dimensión de futuro. Para el derecho el sujeto está atado por el ordenamiento jurídico en general y por las leyes en particular.

Desde lo social entiendo que el sujeto está sujetado por las condiciones sociales que muestra el estado actual del patio en la escuela. La cuestión no es casual, al hablar de la responsabilidad civil en las prácticas del profesor en la escuela. Pero quiero finalizar el trabajo diciendo que el sujeto se constituye, pudiendo constituir identidad en contraposición con las condiciones.

Implica la relación entre libertad y necesidad, al patio hoy en día lo organizamos como podemos no como queremos. Así como el sujeto se constituye la razón se construye, pasando a ser un resultado deseado más que una realidad. El presente puede cambiar a pesar de que la estructura nunca se completa, valorando que la idea de cambiar no 
depende solo de lo que uno puede investigar o lo que uno dice al respecto sino del contexto escolar.

Quiero decir que el sujeto pude producirse en relación a las estructuras pero no depende totalmente de ellas. Un sujeto en las relaciones de poder educativo, que lo atraviesan y lo constituyen permite volver a la noción de sujeto sujetado en una escuela. Permítanme pensar en una escuela transformadora con patios que den seguridad a los profesores y alumnos para no renunciar a proyectos que la sociedad demanda con capacidad de resolver problemas pero también de volver a preguntarse y reflexionar sobre la situación actual del escenario de trabajo.

La discusión sobre el sujeto esta desde mediados del siglo XIX al igual que el problema de la Educación, la educación física desde los orígenes planteaba el dualismo, entre nosotros y la realidad hay interpretaciones con miles de abordajes diferentes. Entre la teoría y la práctica a veces hay oposición y suponemos que hay una relación directa.

Quizás el tiempo de la teoría es un tiempo sin tiempo cuando teorizo intente jugar con ese tiempo de la manera que quería. Todo el trabajo me permitió armar imágenes a medida que daba lugar a los escritos de modo razonado, con términos apropiados. El sujeto se constituye no se construye, lo que se construye es la razón, por lo que la práctica en los profesores del patio debe ser el lugar de la certeza y no se reflexiona.

El problema quizás esté en que los prácticos explican mal la teoría dicen y la pluralidad de saberes tiene que ver con las prácticas como tampoco podemos salir de la teoría que tiene una relación abierta que me invito a pensar en todo momento a media que escribía.

En la conclusión intento decir que más que leyes universales hay principios para la acción, que debemos dar lugar a los debates en términos terminológicos. Kuhn hablaba de pensar en verdades convencionales y las lógicas tienen que ver con las prácticas. A veces cambiar es pelearse con la cultura, las fronteras entre el sujeto y objeto son complicadas y difíciles.

Siempre planteamos un límite, es difícil entender al sujeto, no es educable, es donde la cultura no llega, no quiere decir que se forma de cualquier manera. Todo el resto es educable (persona). Lo que haga con eso sujeto (subjetividad) interior. Al sujeto lo 
leemos en las prácticas, en lo que hace. Todos vivimos interpretando, tiene una eficacia lo que el sujeto puede hacer de ello.

El sujeto es reconocido en sus prácticas, para saber lo que somos, por lo que el cuerpo dice lo que la palabra no dice, el sujeto queda ligado a la palabra o acción. Como Bourdieu intento utilizar la imagen del juego aunque este no sea el producto de una creación y no obedezca a las reglas. Los jugadores entran en el juego y se oponen, sólo porque tienen en común el atribuir al juego y a las creencias (Doña). Quizás en este juego de finalizar el trabajo de la responsabilidad civil en el patio escolar, por el hecho de jugar este juego y no por un contrato quiero decir que valió la pena jugar el juego.

En esto están los principios de la competición y los conflictos, disponiendo seguramente de triunfos, cuyas cartas varían en los diferentes juegos, la jerarquía del capital económico, social, cultural y simbólico en los diferentes campos. En un campo hay luchas, por lo tanto historia, las instituciones luchan, siguiendo las regularidades y las reglas constitutivas de ese espacio de juego. ${ }^{26} \mathrm{La}$ responsabilidad civil es temporal y espacial, el lugar de la prácticas como el tiempo en la escuela es cronológico, intento proponer alternativas de solución a la problemática intentando jugar en ese tiempo dando lugar a enriquecer el tiempo de la vivencia del profesional de la educación física, en su intuición, en los datos, en la transformación, a la autenticidad, en el desnudamiento de todo conocimiento para alcanzar la verdad de cada ser.

Más al interior mismo de la vida del profesional siendo feliz no solamente en la sensación de que el tiempo transcurre en un patio determinado, impuesto, embotellado, enlatado, precario, complicado sino empezando deteniendo quizás la marcha de la planificación, de la eficiencia, del ganarle a los demás y si ganando su tiempo, el instante y el transcurrir de que se puede ser creativo y cambiar el presente, sabiendo del pasado para proyectar el futuro.

La responsabilidad civil en las prácticas del profesor desde los enfoques tradicionales deben dar lugar a los nuevos en un paradigma crítico como mirada, en una enseñanza basada en la construcción centrada en el saber, saber hacer y la actitud.

Me sigo preguntando, con nuevas respuestas que me acercan al camino de la verdad que busco durante años sobre esta temática tan importante. Al principio el

\footnotetext{
${ }^{26}$ Pierre Bourdieu. La lógica de los campos. Artículo.
} 
desconocimiento me fue dando información, luego conociendo el problema fui descubriendo lo invisible para dar lugar a un determinado saber que sigue alimentando mi búsqueda.

Queda atrás un camino recorrido, con aspectos sumamente positivos que dan luz a las realidades diarias del contexto escolar de la educación física actual. Nos merecemos una educación física basada en un paradigma crítico, Finalmente pude terminar una tarea encomendada que tiene muchos actores, problemáticas y preguntas sin respuestas hace años que ahora las puedo presentar luego de indagar a quienes fueron parte.

En los establecimientos educativos la responsabilidad civil, espera una mochila más o menos pesada de acuerdo a como se trabajó en la Prevención, en la Anticipación, en la posibilidad de poder actuar razonablemente ante un hecho que luego se informa de algún accidente cuyas circunstancias, personas afectadas se detallen con alguna lesión sufrida no se haya actuado con imprudencia o negligencia,

Las formas y la actividad de cómo ocurrió el accidente como el nombre del profesional a cargo, si hubo intervención policial, si se llamó al servicio de emergencias médica, si existió otra asistencia médica, si hubo testigos y si ocurrió bajo autoridad educativa. Por eso como importante es necesario recuperar en cada contexto la información del diagnóstico realizado el inicio de cada ciclo escolar, las medidas previstas y las evaluaciones efectuadas durante el proceso.

Los límites son temporales, desde el horario de entrada hasta la salida de clase o de cualquier otra actividad que sea convocada por las autoridades del colegio y que se lleve a cabo tanto dentro como fuera de los límites del mismo. También los límites espaciales que es el lugar que desempeña la función, este termina en la puerta de la calle del edificio escolar o centro deportivo, por lo tanto allí termina la responsabilidad de las autoridades escolares.

El deber de vigilancia, la guarda provisoria, desde el compromiso profesional y el deber de diligencia que tiene en la responsabilidad contractual que tiene el origen en el cumplimiento de la obligación concreta, a mayo jerarquía, mayor obligación, mayor responsabilidad. La ley establece lo permitido y lo prohibido crea en los hombres exclusiones, sin norma no hay disciplina, porque el espacio de la norma es aquello que no está legislado en el que se puede ejercer la arbitrariedad de considerar a alguien 
normal o no sostenerlo a una sanción no a una condena. Los patios de educación física en las escuelas investigados no están reglamentados, es más en escuelas tiene problemas al no tener el espacio adecuado a las prácticas.

La arquitectura escolar generó asimetría de poder en la normalización de cuerpos, esta identificó a las instituciones. Aparecieron los dispositivos de vigilancia, cuyo poder estaba expresado en el espacio escolar. Los orígenes de la educación en nuestro país sus momentos fundacionales del sistema era normalizar. La falta de identidad se presentaba en su momento con una mirada puesta en Europa. Se pretendía con las escuelas del movimiento construir templos del saber.

El ordenamiento de cuerpos y prácticas sociales en las escuelas, no las clases afuera de las mismas, lo que no generaba reconocimiento, con un marcado ordenamiento espacial con un punto importante facilitar vigilancia hacia los alumnos con ideas de poder muy bien pensadas. Esas escuelas reproducen techos a dos aguas, con la figura de la maestra como la segunda mamá. Escuelas cerca de los edificios del Poder, arquitecturas contenedoras del proyecto de habilitaciones de una población postergada.

Los cambios de las arquitecturas, urgencias a corto plazo, con espacios para los recreos, con la idea si van a ser cuidados o no. Una disputa de espacios de fin de siglo con una escuela contenedora. Por años el tiempo, espacio y poder con una reflexión que hacen los actores con idea de mapa, con una idea de lucha de poder por los espacios, con los sujetos.

Esos espacios son disputa de poder, con variables temporales con agenda de rituales las que podemos considerar o no. Por eso es importante planificar o elabora proyectos para conocer el estado actual de los patios escolares, con sus recursos humanos, los pasos, las horas o módulos, espacios para la práctica como la manera de usar el tiempo, las temporalidades individuales como la toma de decisiones.

La conclusión brinda objetivos para llevar adelante con la responsabilidad civil en la escuela, específicamente en el patio de prácticas del profesor de educación física. Brindar herramientas teóricas como metodológicas para la construcción de proyectos, a través del diagnóstico actual del patio, mostrar el estado actual de los mismos en un distrito, basado en el estudio realizado y diseñar futuros proyectos estratégicos, contemplando variables en la cultura escolar. 
Si la observación es un elemento clave de la gestión curricular, entre ellas las prácticas institucionales y en especial las que se desarrollan en el patio con el profesional de la educación física sería interesante abordar este tema desde los significados que estas prácticas tienen en las instituciones educativas y ofrecer elementos interesantes para pensar sobre la práctica. La mirada de los patios escolares en un proceso de años me situó más allá de la percepción y suponer que no hay una mirada inocente e ingenua.

El peso de la responsabilidad civil en el saber de los profesionales debería ser reconocido en el contexto actual y para el marco de la transformación educativa se hace necesario re pensar las prácticas hacia una visión estratégica que le permita a los profesores de educación física con los directivos oficiar como líder en innovación, investigación y cambio institucional. Esta mirada seguramente ubica de modo diferente a quienes tienen decisión y ejecución bajo una lógica que no es posible pensarlas por separado con nuevos sujetos pedagógicos revisando la gestión institucional.

La responsabilidad civil se ha convertido en las instituciones a la luz de las situaciones que cotidianamente impactan en las mismas, en una cuestión frente a la cual ya no es suficiente la sola referencia a la norma vigente. Hay una debilidad en la normativa y adecuarla al contexto es importante, a veces producen trastornos legales en el cual los sistemas están sometidos a cambios con bastante frecuencia a causa del constante progreso en que vivimos. No hay sociedad sin normas, sean jurídicas, morales o religiosas.

\section{Bibliografía}

Albornoz, A.F., 1996, "El Profesor de Educación Física y su responsabilidad civil", Ediciones del Este. 
Ackermann, Cohen, Izbicki, Keskiskian, Larosa, 2004, "Patios de Juego, Seguridad" Centro Metropolitano de diseño. Nobuko.

Angriman, M.A., 2003, "Legislación de la Actividad Física y el Deporte”, Buenos Aires, Editorial Stadium.

Angriman, M.A., 2005, "Responsabilidad y Prevención en Actividad Físicas y Deportivas" Legislación - Doctrina - Jurisprudencia, Editorial Stadium.

Angriman, M.A., 2007, "Preguntas y Respuestas" De Legislación de la Actividad Física, Escolar y Deportiva. Editorial Stadium.

Bracht, Walter, Crisorio, R., 2003, "La Educación Física en la Argentina y Brasil", Identidad, desafíos y perspectivas., Ediciones Al Margen.

Carballo, Carlos, 2003, "Proponer y Negociar", El ocaso de las tradiciones Autoritarias en las prácticas de la educación física, Ediciones Al Margen.

Código Civil de la República Argentina. (artículos del Código Civil).

Foucault, M., 1978 ,"La verdad y las formas Jurídicas”, Editorial Gedisa.

Giddens, A-. 2006., "La Constitución de la Sociedad, Bases para la teoría de la Estructuración", 1 ed. 3 reimpresión. Editorial Amorrortu.

Iturraspe, J.M. 2da. (Reimpresión, 1997), 1era. (Reimpresión, 1993), 1era. (Edición 1992) "Responsabilidad Civil", Ediciones Depalma.

Loizaga, E., 1999, "La Responsabilidad Civil de los Establecimientos Educativos", Buenos Aires, E.Abeledo Perrot.

Pavia, Victor, 2005, "El patio escolar: el juego en libertad controlada", Un lugar emblemático territorio de pluralidad., 1era. Edición, Ediciones Novedades Educativas. 
Puiggrós, Adriana, 2006, "Sujetos, Disciplina y Currículo", en los orígenes del Sistema Educativo Argentino, (1885 - 1916)., Editorial Galerna,

Puiggrós, Adriana, Historia de la Educación en la Argentina. Sujetos. Disciplina y Curriculo. Orígenes del Sistema Educativo Argentino. 1885 - 1916

Rauch, André, 1985, "El cuerpo en la Educación Física”, serie / Los nuevos Problemas Educativos, Kapelusz.

Sagarna, A. F., 1996, "Responsabilidad Civil de los Docentes y de los Institutos de Enseñanza, 2da. Edición (primera edición 1994), Buenos Aires, Ediciones Depalma.

Constitución Provincial de la República Argentina.

Constitución Nacional de la República Argentina.

Código Civil de la Republica Argentina.

Leyes

Ley 26.061

Ley de Educación Nacional 26.206

Ley de Educación Provincial 13.688

Ley 11.612

Ley 10.579

Estatutos 
Estatuto del Docente de la Provincia de Buenos Aires y su Reglamentación, FEB, 2011, Federación de Educadores Bonaerenses, La Plata.

Resoluciones

Resolución 12.231. Reglamento para la educación física en los Establecimientos de Educación Media, Técnica y Agraria.

Resolución Ministerial Número 426 / 06, Normativa para la realización de experiencias directas, lecciones paseo y / o salidas bajo el control de la autoridad educativa.

Resolución Número 2.150 / 05. Uso compartido de Edificios Escolares.

Resolución Ministerial Número 3.113, Otorgamiento de Autorizaciones de los Organismos de la Dirección General de Cultura y Educación.

Resolución Ministerial Número 1.001 / 85.

Circulares

Circular Conjunta 1 / 09. El profesor de educación física en instituciones de nivel inicial.

Circular Técnica Conjunta 1/97, objeto: pauta para el dictado de educación física en establecimiento de EGB.

Circular Número 7 / 94, atento a las situaciones planteadas y con el objeto de clarificar e informar acerca de la prevención de accidentes y emergentes responsabilidad civil.

Circular 2 / 2010, Pautas para dictado en el medio acuático. Circular 1 / 2010, encuentros masivos inter escolares.

Artículos 
Jornadas de Capacitación de la Federación de Educadores Bonaerenses, Prevención de accidentes en Instituciones Educativas, Leyes Laborales Vigentes y ámbito educativo, responsabilidad civil en el trabajo docente.

Seminarios de Licenciatura en Educación Física de Universidad de Humanidades de La Plata, ciclo 2002 - 2003, Material Bibliográfico. Problemas Jurídicos en el Campo de Las Prácticas Corporales.

Cristina Varela, Apuntes de Jornada de Responsabilidad Civil.

Documento Nro. 1 del 18 / 09 / 2000, Orientaciones para el abordaje de la Responsabilidad Civil, accidentes escolares, prevención y atención.

Capacitación de Responsabilidad Civil, Centro de Formación en Administración Pública.

Apuntes de Seguro de Responsabilidad Civil, Provincia Seguros.

Herrera, Lopez, Introducción a la Responsabilidad Civil.

Ibañez, Carlos, Asesoramiento Jurídico de Docentes.

Sanchez, J., Latorre, P., Análisis de los espacios y equipamiento deportivo escolar, seguridad.

Cebey, Carlos, Jornada de Responsabilidad Civil.

Cachorro, Gabriel, Facultad de Humanidades y Ciencias de la Educación. Descontrucción de una labor arquitectónica, Maestria en Educación Corporal, La Plata,

Delgado J. y Gutierrez (1995). Métodos y Técnicas cualitativas de Investigación en Ciencias Sociales. 
Peter Woods, 1996. La Escuela por dentro. La etnografía en la investigación educativa.

Bourdieu Pierre, 1995, El oficio del Sociólogo.

Bourdieu Pierre, artículo la lógica de los campos.

Documentos Centro de Formación en la Administración Pública de Responsabilidad Civil en el ejercicio de la función.

Publicaciones en los medios periodísticos del Diario Ecos Diarios (Necochea). Diario El Día (La Plata) 